GLOBAL WATER PATHOGEN PROJECT

PART THREE. SPECIFIC EXCRETED PATHOGENS: ENVIRONMENTAL AND EPIDEMIOLOGY ASPECTS

\title{
VIBRIO CHOLERAE AND CHOLERA BIOTYPES
}

\section{Maggy Momba}

Tshwane University of Technology South Africa

Pretoria, South Africa

Mohamed Azab El-Liethy

Tshwane University of Technology South Africa

Pretoria, South Africa 


\section{Copyright:}

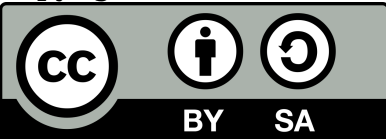

This publication is available in Open Access under the Attribution-ShareAlike 3.0 IGO (CC-BY-SA 3.0 IGO) license (http://creativecommons.org/licenses/by-sa/3.0/igo). By using the content of this publication, the users accept to be bound by the terms of use of the UNESCO Open Access Repository (http://www.unesco.org/openaccess/terms-use-ccbysa-en).

\section{Disclaimer:}

The designations employed and the presentation of material throughout this publication do not imply the expression of any opinion whatsoever on the part of UNESCO concerning the legal status of any country, territory, city or area or of its authorities, or concerning the delimitation of its frontiers or boundaries. The ideas and opinions expressed in this publication are those of the authors; they are not necessarily those of UNESCO and do not commit the Organization.

\section{Citation:}

Momba, M. and Azab El-Liethy, M. (2017). Vibrio cholerae and Cholera biotypes. In: J.B. Rose and B. Jiménez-Cisneros, (eds) Water and Sanitation for the 21st Century: Health and Microbiological Aspects of Excreta and Wastewater Management (Global Water Pathogen Project). ( A. Pruden, N. Ashbolt and J. Miller (eds), Part 3: Specific Excreted Pathogens: Environmental and Epidemiology Aspects - Section 2: Bacteria), Michigan State University, E. Lansing, MI, UNESCO. https://doi.org/10.14321/waterpathogens.28

Acknowledgements: K.R.L. Young, Project Design editor; Website Design: Agroknow (http://www.agroknow.com)

Last published: March 22, 2018 


\section{Summary}

Vibrio cholerae, with strains that cause cholera, is a motile, Gram-negative curved rod belonging to the family Vibrionaceae. Although approximately 200 recognized $O$ serogroups have been identified, only serogroups $\mathrm{O} 1$ and O139 strains are known to cause severe disease and cholera pandemics. Intestinal and/or extra-intestinal infections with non-01 and non-0139 serogroups or nontoxigenic 01 strains are seldom found and seem to have little impact on public health. Serogroup $\mathrm{O} 1$ and 0139 pandemic strains exist as natural inhabitants of aquatic ecosystems, making them facultative human pathogens. $V$. cholerae serogroup $\mathrm{O} 1$ has two biotypes (classical and $\mathrm{El}$ Tor) and three serotypes (Ogawa, Inaba and Hikojima). The most prevalent serotype is Ogawa, whereas Hikojima is very rare and unstable in the environment. Non-O1 and non-0139 $\mathrm{V}$. cholerae strains are more frequently isolated from rivers and estuarine areas compared to $\mathrm{O} 1$ and $\mathrm{O} 139$ strains. There is evidence that the cholera toxin (CT)encoded phage CTX $\phi$ can transduce these non-toxigenic environmental strains, converting them into toxigenic strains, an event that has been postulated to also take place in the gastrointestinal environment resulting in the detection of toxigenic strains.

In the past, the permanence of toxigenic $V$. cholerae in the environment was considered short and cholera outbreaks have been mainly driven by fecal-oral transmission. Currently, it has been found that $V$. cholerae could survive for a long time in the water, assuming a viable, but non-culturable state. This finding pointed to a new hypothesis, namely that an environmental reservoir of $V$. cholerae is responsible for endemic cholera, and a corresponding cholera epidemiology framework was formulated that incorporates an envionmental $V$. cholerae reservoir. The role of the aquatic environment on maintenance of cholera dynamics depends on the sanitary condition of the community. Endemism in a well-sanitized community requires a permanent environmental reservoir, while endemism in a poor community requires only a transient reservoir.

Onset of cholera as a disease is the result of a multifactorial process, involving several genes encoding virulence factors that aid $V$. cholerae in its colonization, coordinated expression of virulence factors, and toxigenicity. Vibrio cholerae also acquire virulence genes in a step-by-step process, in which a pathogenicity island and a temperate bacteriophage play important roles. Globally, cholera represents an estimated burden of 1.4 to 4.3 million cases and 28,000 to 142,000 deaths per year. Even though considerable efforts have been made by many countries to contain the spread of cholera, it is now endemic in many countries and there is growing concern over the increasing number of people living in unsanitary conditions and being at risk of contracting cholera and other epidemic-prone diarrhoeal diseases.

This chapter aims to provide the reader with a broad understanding of recent discoveries of $V$. cholerae and new recombinant $V$. cholerae biotypes and an outlook toward future developments. Using the very latest international scientific research, this chapter outlines historical perspective and classification, methods (molecular and culture-based) proposed for the detection and isolation in waters and environmental occurrence, persistence and survival of Vibrio cholerae and their biotypes, the route of transmission and the global distribution of cholera as well as its control by vaccination and good sanitation and hygiene interventions to reduce the incidence of cholera outbreaks. A comprehensive and multidisciplinary approach to cholera prevention and control is provided to assist communities and policy-makers in averting cholera outbreaks.

\section{Vibrio cholerae and Cholera biotypes}

Vibrio cholerae is a normal inhabitant of aquatic environments such as drinking water, freshwater, wastewater, brackish water and sea water. This bacterium consists of a wide variety of strains and biotypes, capable of receiving and transferring genes for toxins (Waldor and Mekalanos, 1996), colonization factors (Brown and Taylor, 1995; Karaolis et al., 1999), antibiotic resistance (Hochhut and Waldor, 1999), capsular polysaccharides that provide resistance to chlorine (Yildiz and Schoolnik, 1999) and surface antigens such as the 0139 lipopolysaccharide and O antigen capsule (Bik et al., 1995; Waldor et al., 1994). As a species, $V$. cholerae includes both pathogenic and nonpathogenic strains that generally differ in their virulence gene content (Faruque et al., 1998). Although, $V$. cholerae contains more than 200 serotypes based on its $\mathrm{O}$ antigen, only serotypes $\mathrm{O} 1$ and 0139 are known as the causative agents of epidemic and pandemic cholera outbreaks (Bag et al., 2008). These serotypes are characterized by their ability to produce cholera toxin that is encoded by ctx gene (Kaper et al., 1995), which has been used for specific detection of choleragenic $V$. cholerae in environmental samples (Karunasagar et al., 1997). Certain phenotypic and genetic properties are used to categorise Vibrio cholerae $\mathrm{O} 1$ into two biotypes: classical and El Tor.

In recent years, the rise and spread of new pathogenic variants of $V$. cholerae has been reported throughout many countriesr, especially in Asia (Na-Ubol et al., 2011; Tran et al., 2012) and Africa (Ceccarelli et al., 2011; Naha et al., 2013) as well as in Mexico (Alam et al., 2012). These include the Matlab (MT) variant from Bagladesh (Nair et al., 2002) and the Mozambic variants, an atypical El Tor strain harbouring CTX $\Phi^{\text {Cla }}$ (Faruque et al., 2007b; Das et al., 2007). Similar strains carrying tandem copies of CTX $\Phi^{\text {cla }}$ in the small chromosome or in large chromosome have also been isolated in other parts of world (Nair et al., 2006; Nguyen et al., 2009). The Haitian variant of the El Tor biotype has been reported to contain a unique mutation at the 58th nucleotide of $c t x B$ (the gene for the $B$ subunit of cholera toxin) (Nair et al., 2006) that has completely replaced the El Tor biotype on Kolkata, India, since 1995 (Raychoudhuri et al., 2009). Haitian V. cholerae strain also 
had a novel mutation at the $64^{\text {th }}$ amino acid position of the matured TcpA subunit (Naha et al., 2012; Ghosh et al., 2014).

Serogroups, which exclude choleragenic 01 and 0139, are categorized as $V$. cholerae non-01 and non-0139, or non-agglutinating vibrios (NAGs) (Hasan et al. 2012; Dutta et al., 2013). Such non-agglutinating serogroups have less than 200 somatic (O) antigens and mostly lack cholera toxins coding genes (Shin et al. 2011; Marin et al. 2013). While the non-O1 and non-0139 serotypes are rarely associated with human infections, they are able to cause only gastroenteritis or even septicemia but not cholera disease (West, 1989; Powell, 1999). The infection by non-O1 and non-O139 is characterized by diarrhea, abdominal cramps, and fever in sever cases where this disease is self limiting and controlling in most of the cases. Vibrio species demonstrate a significant portion of the culturable heterotrophic bacteria of aquatic environments (Stabili and Cavallo, 2004). It is not easy to distinguish 01 from non-O1 by general laboratory methods (Singh et al., 2004).

The ability of $V$. cholerae to persist in the environment plays a role in the intensity of the cholera outbreak. This bacterial species has both a tendency to trigger epidemics with pandemic potential and the ability to stay endemic in all affected areas. In the epidemic setting, the entire population is susceptible to infection at the start of the epidemic due to little or naturally acquired immunity to cholera (Kaper et al., 1995; Faruque et al., 2007a). In contrary in highly endemic areas, the population had prior exposure to $V$. cholerae and at least some immunity to reinfection (Faruque et al., 2007a). In other words, in the endemic settings, there may be slower decay rates for $V$. cholerae in the environment, or positive growth during some seasons of the year. This can enable the long-term persistence of cholera even when conditions are not favourable for the transmission of the disease to human (Epstein, 1993; Colwell and Huq, 1994).

In general, cholera is endemic where socioeconomic conditions are poor, sanitary systems and public hygiene are rudimentary, and safe drinking water is not available, especially during floods. Such situations are even more hazardous to human health in countries in which fuel for boiling water is in scarce supply (Siddique et al., 1992). A broad understanding of recent discoveries of $V$. cholerae and new recombinant $V$. cholerae biotypes, as well as evolution and spread is therefore needed for an outlook toward future developments.

\subsection{Epidemiology of the Disease and Pathogen(s)}

Epidemiologically, cholera is described as a disease that has its tendency to cause explosive outbreaks and its potential to cause pandemics. It appears to exhibit three major epidemiological patterns: i) heavily endemic or epidemic in areas with poor sanitation and without clean water; ii) neo-epidemic in newly invaded cholera-receptive areas; and iii) occasional limited outbreaks in developed countries with good sanitation. Cholera has both a predisposition to cause epidemics with pandemic potential and an ability to remain endemic in all affected areas. While people of all ages are at risk of contracting the infection in epidemic settings, children older than two years are the target group mostly affected in these areas.

Historically, there have been descriptions of a disease resembling cholera in an ancient Indian medical treatise, the Sushruta Samhita, written in Sanskrit $~ 500$ to 400 B.C. (Bishagratna, 1963). Historical records tracing back 2000 years in both Greek and Sanskrit also point to the description of diseases similar to cholera (Lacey, 1995). This means that cholera existed long before the 1817 pandemic, the first of the seven recorded pandemics (Colwell, 1996). In 1849, Dr John Snow, an English physician, recognized that cholera was spread through contaminated water and he devised methods for the prevention and control of this disease (Keen and Bujalski, 1992; Shears, 1994).

Vibrio as a microorganism was accurately described by Filippo Pacini in 1854 and isolated by Robert Koch and his collaborators in 1883. In 1885, Robert Koch discovered that $V$. cholerae was the causative organism of cholera and that the cholera toxin was found to be the agent leading to severe diarrhoea (Shears, 1994). In 1953, the two bacteriologists, De and Chatterjee in Kolkata, West India, discovered the crude cholera toxin, responsible for stimulating fluid secretion from the small intestine (Maheshwari et al., 2011). During the $19^{\text {th }}$ century and even still today, the pread of cholera epidemics has resulted in many waves of infection. Since 1817, the world has acknowledged seven cholera pandemics. The first six pandemics are assumed to have started in the Ganges River delta. The seventh pandemic, which continues today, started in 1961 in Sulavesi, Indonesia (Shears, 1994). The first five pandemics were caused by the classical biotype, while the classical strains appear to be the causative agent of the sixth pandemic (Pollitzer, 1959). Between the sixth and seventh pandemics, there was an intervening period of 38 years during which cholera only occurred as local outbreaks caused by El Tor strains (Safa et al., 2010). Figure 1 illustrates the seven pandemic cholera events from 1817 to 2010. 


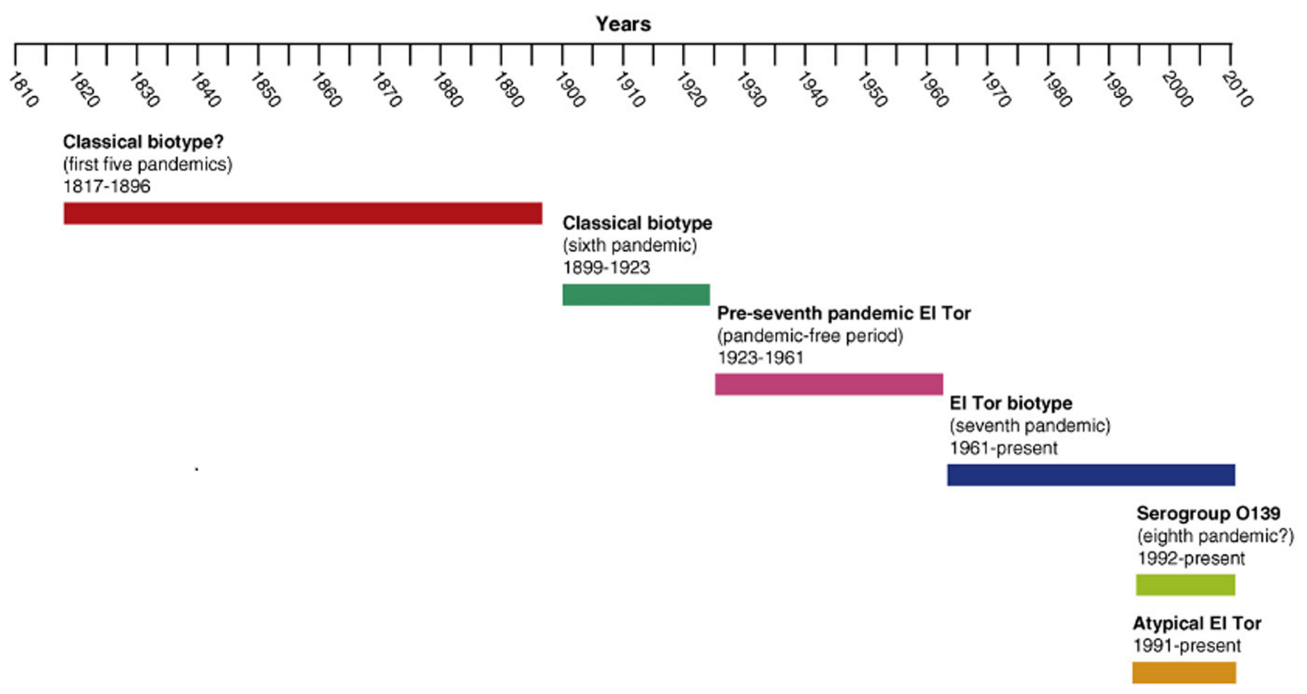

Figure 1. The seven pandemic cholera events from 1817 to 2010. Reproduced with the permission of the authors Sara A and King R.Y. (Sara et al., 2010).

\subsection{Global burden of disease}

Worldwide, cholera still remains a major public health concern, although the risk of infection differs from one country to another. While cholera outbreaks have been reported with minor cases in Australia and America, the most affected continents are mainly Asia and Africa, with
Sub-Saharan Africa being the centre of several cholera epidemics and where the risk associated with cholera infection is high (Figure 2). Detailed accounts of the history of cholera are available, but the 1990s was found to be a crucial decade in the history of cholera as a remarkable increase in the global incidence of this disease was recorded. Thus, this section focuses on the reports of cholera outbreaks between 1995 and 2017.

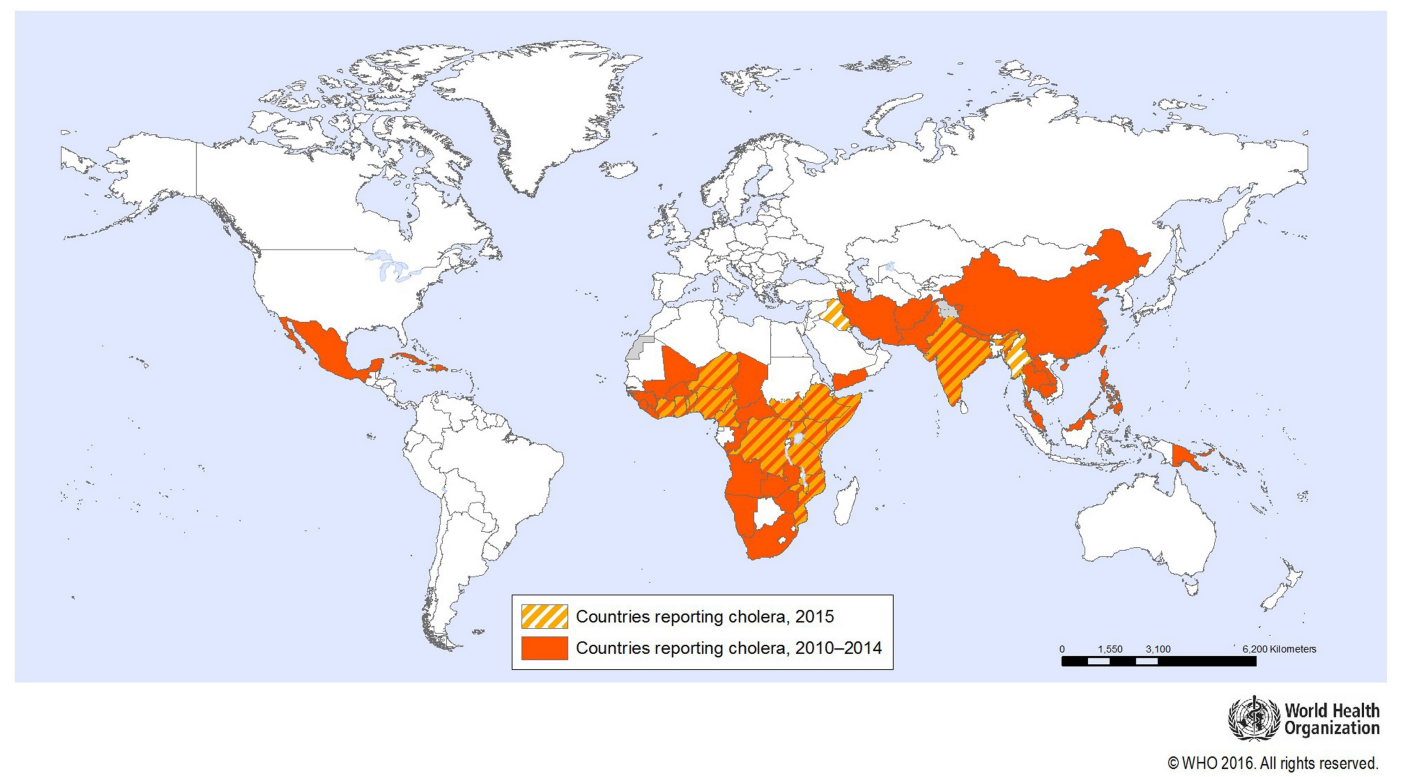
(2016)]

Figure 2. Map of countries reporting on cholera between 2010 and 2015. [Extracted with the permission of WHO

\subsubsection{Global distribution}

Basically, the majority of cholera cases are not reported regularly by many countries and the limited factors include not only inadequate capacity of epidemiological surveillance and laboratories, but also the social, political, 
and economic hindrances (Ali et al., 2015). The World Health Organization (WHO) maintains a repository of reported cases and deaths, and publishes annual statistics in the Weekly Epidemiological Record (WER). Nevertheless if the number of cholera cases occurring in a country is not reported, this country is automatically classified as a cholera free area.

According to WHO (2014), the cholera cases reported annually range between 5 and $10 \%$. The reports of cholera provided by the WHO from 1995 to 2016 include the cholera outbreaks, deaths and CFR reported in Africa, Asia,
Europe, Americas and in Oceania, annually (WHO, 1996-2017). The numbers of countries in each continent have been determined based at least on one cholera case reported per year during the selected period. Taking into consideration this criterion, there has been at least one cholera case per year in 48 African countries, 38 countries in Asia, 24 countries in Europe, 23 countries in Americas and 7 countries in Oceania (Tables $1 \mathrm{~A}$ and 1B). Although the European continent had a higher number of reporting countries than America, the majorities of outbreak cases reported in Europe were imported cases and the number of fatalities was very low.

Table 1A. Total number of cholera cases and deaths in the five continents reported by WHO, and case fatality $^{\mathrm{a}}$ rate(CFR), from 1995 to 2005 . The total cases, deaths and case fatality rate for 95-2005 was 1,855,542 cases, 56,470 deaths and 3.04 CFR

\begin{tabular}{|c|c|c|c|c|c|c|c|}
\hline \multirow{2}{*}{$\begin{array}{l}\text { Year } \\
\text { (Number }^{\text {reporting in }} \\
\text { that year) }^{\mathbf{b}}\end{array}$} & \multicolumn{7}{|c|}{ Continent (number of countries that report in each) } \\
\hline & & $\begin{array}{c}\text { Africa } \\
(\mathbf{4 8 )}\end{array}$ & $\begin{array}{c}\text { Americas } \\
\text { (23) }\end{array}$ & $\begin{array}{l}\text { Asia } \\
\text { (38) }\end{array}$ & $\begin{array}{c}\text { Europe } \\
\text { (24) }\end{array}$ & $\begin{array}{c}\text { Oceania } \\
\text { (7) }\end{array}$ & TOTAL \\
\hline 1995 & Cases & 71,081 & 85,809 & 50,921 & 937 & 7 & 208,755 \\
\hline \multirow[t]{2}{*}{$(78)$} & Deaths & 3,024 & 845 & 1,145 & 20 & 0 & 5,034 \\
\hline & $\mathrm{CFR}^{\mathrm{a}}$ & 4.2 & 0.98 & 2.24 & 2.13 & 0 & 2.41 \\
\hline 1996 & Cases & 108,535 & 24,643 & 10,142 & 13 & 4 & 143,337 \\
\hline \multirow[t]{2}{*}{ (67) } & Deaths & 6,216 & 351 & 122 & 0 & 0 & 6,689 \\
\hline & CFR & 5.7 & 1.42 & 1.20 & 0 & 0 & 4.66 \\
\hline 1997 & Cases & 118,349 & 17,760 & 11,293 & 18 & 5 & 147,425 \\
\hline \multirow[t]{2}{*}{ (67) } & Deaths & 5,853 & 225 & 196 & 1 & 0 & 6,275 \\
\hline & CFR & 4.9 & 1.26 & 1.8 & 7.69 & 0 & 4.25 \\
\hline 1998 & Cases & 211,748 & 57,106 & 24,212 & 47 & 8 & 293,121 \\
\hline \multirow[t]{2}{*}{$(74)$} & Deaths & 9,856 & 558 & 172 & 0 & 0 & 10,586 \\
\hline & CFR & 4.6 & 1.18 & 0.71 & 0 & 0 & 3.61 \\
\hline 1999 & Cases & 206,746 & 8,126 & 39,417 & 16 & 5 & 254,310 \\
\hline \multirow[t]{2}{*}{$(60)$} & Deaths & 8,728 & 103 & 344 & 0 & 0 & 9,175 \\
\hline & CFR & 4.2 & 1.26 & 0.84 & 0 & 0 & 3.60 \\
\hline 2000 & Cases & 118,932 & 3,101 & 11,246 & 35 & 3,757 & 137,071 \\
\hline \multirow[t]{2}{*}{ (56) } & Deaths & 4,610 & 40 & 232 & 0 & 26 & 4,908 \\
\hline & CFR & 4.87 & 1.28 & 2.06 & 0 & 0.69 & 3.58 \\
\hline 2001 & Cases & 173,359 & 535 & 10,340 & 58 & 19 & 184,311 \\
\hline \multirow[t]{2}{*}{ (58) } & Deaths & 2,590 & 0 & 138 & 0 & 0 & 2,728 \\
\hline & CFR & 1.49 & 0 & 1.33 & 0 & 0 & 1.48 \\
\hline 2002 & Cases & 137,866 & 23 & 4,409 & 7 & 6 & 142,311 \\
\hline \multirow[t]{2}{*}{ (52) } & Deaths & 4,551 & 0 & 13 & 0 & 0 & 4,564 \\
\hline & CFR & 3.3 & 0 & 0.291 & 0 & 0 & 3.20 \\
\hline 2003 & Cases & 108,067 & 33 & 3,463 & 12 & 0 & 111,575 \\
\hline \multirow[t]{2}{*}{$(45)$} & Deaths & 1,884 & 0 & 10 & 0 & 0 & 1,894 \\
\hline & CFR & 1.74 & 0 & 0.288 & 0 & 0 & 1.69 \\
\hline 2004 & Cases & 95,560 & 36 & 5,764 & 21 & 2 & 101,383 \\
\hline \multirow[t]{2}{*}{ (56) } & Deaths & 2,331 & 0 & 14 & 0 & 0 & 2,345 \\
\hline & CFR & 2.43 & 0 & 0.24 & 0 & 0 & 2.31 \\
\hline 2005 & Cases & 125,082 & 24 & 6,824 & 10 & 3 & 131,943 \\
\hline \multirow[t]{2}{*}{$(51)$} & Deaths & 2,230 & 0 & 42 & 0 & 0 & 2,272 \\
\hline & CFR & 1.78 & 0 & 0.62 & 0 & 0 & 1.72 \\
\hline
\end{tabular}

${ }^{\mathrm{a}}$ Case Fatality Rate; ${ }^{\mathrm{b}}$ Total countries reporting that year 
Table 1B. Total number of cholera cases and deaths in the five continents reported by WHO, and case fatality $^{\text {a }}$ rate(CFR), from 2006 to 2016.

The total cases, deaths and case fatality rate for 2006-2016 was 2,603,189 cases, 46,881 deaths and 1.8 CFR

\begin{tabular}{|c|c|c|c|c|c|c|c|}
\hline \multirow{2}{*}{$\begin{array}{l}\frac{1}{c} \text { Year } \\
\text { (Number } \\
\text { reporting in } \\
\text { that year) }^{b}\end{array}$} & \multicolumn{7}{|c|}{ Continent (number of countries that report in each) } \\
\hline & & $\begin{array}{c}\text { Africa } \\
\text { (48) }\end{array}$ & $\begin{array}{c}\text { Americas } \\
\text { (23) }\end{array}$ & $\begin{array}{c}\text { Asia } \\
\text { (38) }\end{array}$ & $\begin{array}{c}\text { Europe } \\
\text { (24) }\end{array}$ & $\begin{array}{c}\text { Oceania } \\
\text { (7) }\end{array}$ & TOTAL \\
\hline 2006 & Cases & 234,349 & 10 & 2,472 & 62 & 3 & 236,896 \\
\hline \multirow[t]{2}{*}{$(52)$} & Deaths & 6,303 & 0 & 8 & 0 & 0 & 6,311 \\
\hline & $\mathrm{CFR}^{\mathrm{a}}$ & 2.69 & 0 & 0.32 & 0 & 0 & 2.66 \\
\hline 2007 & Cases & 166,583 & 8 & 11,325 & 44 & 3 & 177,963 \\
\hline \multirow[t]{2}{*}{$(53)$} & Deaths & 3,994 & 0 & 37 & 0 & 0 & 4,031 \\
\hline & CFR & 2.4 & 0 & 0.33 & 0 & 0 & 2.27 \\
\hline 2008 & Cases & 179,323 & 7 & 10,778 & 22 & 0 & 190,130 \\
\hline \multirow[t]{2}{*}{ (56) } & Deaths & 5,074 & 0 & 69 & 0 & 0 & 5,143 \\
\hline & CFR & 2.83 & 0 & 0.64 & 0 & 0 & 2.7 \\
\hline 2009 & Cases & 217,333 & 17 & 1,902 & 17 & 1957 & 221,226 \\
\hline \multirow[t]{2}{*}{$(45)$} & Deaths & 4,883 & 0 & 18 & 0 & 45 & 4,946 \\
\hline & CFR & 2.53 & 0 & 0.95 & 0 & 2.3 & 2.24 \\
\hline 2010 & Cases & 115,106 & 179,594 & 13,819 & 15 & 9000 & 317,534 \\
\hline \multirow[t]{2}{*}{ (48) } & Deaths & 3,397 & 3,990 & 60 & 1 & 95 & 7,543 \\
\hline & CFR & 2.95 & 2.22 & 0.434 & 6.66 & 1.056 & 2.37 \\
\hline 2011 & Cases & 188,678 & 361,266 & 38,298 & 71 & 1541 & 589,854 \\
\hline \multirow[t]{2}{*}{ (58) } & Deaths & 4,183 & 3205 & 426 & 0 & 2 & 7,816 \\
\hline & CFR & 2.22 & 0.89 & 1.11 & 0 & 0.13 & 1.33 \\
\hline 2012 & Cases & 117,570 & 120,433 & 7,369 & 18 & 5 & 245,395 \\
\hline \multirow[t]{2}{*}{ (48) } & Deaths & 2,042 & 965 & 27 & 0 & 0 & 3,034 \\
\hline & CFR & 1.7 & 0.8 & 0.4 & 0 & 0 & 1.23 \\
\hline 2013 & Cases & 56,329 & 61,152 & 11,576 & 7 & 3 & 129,067 \\
\hline \multirow[t]{2}{*}{ (47) } & Deaths & 1,366 & 636 & 100 & 0 & 0 & 2,102 \\
\hline & CFR & 2.43 & 1.01 & 0.86 & 0 & 0 & 1.62 \\
\hline 2014 & Cases & 105,287 & 28,456 & 56,787 & 17 & 2 & 190,549 \\
\hline \multirow[t]{2}{*}{ (42) } & Deaths & 1,882 & 307 & 42 & 0 & 0 & 2,231 \\
\hline & CFR & 1.79 & 1.08 & 0.07 & 0 & 0 & 1.17 \\
\hline 2015 & Cases & 71,176 & 36,664 & 64,590 & 22 & 2 & 172,454 \\
\hline \multirow[t]{2}{*}{ (42) } & Deaths & 937 & 337 & 30 & 0 & 0 & 1,304 \\
\hline & CFR & 1.3 & 0.9 & 0.05 & 0 & 0 & 0.75 \\
\hline 2016 & Cases & 71,058 & 42,595 & 18,445 & 22 & 1 & 132,121 \\
\hline \multirow[t]{2}{*}{ (38) } & Deaths & 1,762 & 474 & 184 & 0 & 0 & 2,420 \\
\hline & CFR & 2.5 & 1.1 & 1.0 & 0 & 0 & 1.83 \\
\hline
\end{tabular}

${ }^{\mathrm{a} C a s e}$ Fatality Rate ; ${ }^{\mathrm{b}}$ Total countries reporting that year 
Table 2. Incidence of $\boldsymbol{V}$. cholerae in African countries

\begin{tabular}{|c|c|c|}
\hline Area & Incidence $^{\mathrm{a}}$ & Reference \\
\hline Angola & 108,319 & WHO 1996-2014 \\
\hline Benin & 18,779 & WHO 1996-2014 \\
\hline Botswana & 23 & WHO 1996-2014 \\
\hline $\begin{array}{l}\text { Burkina- } \\
\text { Faso }\end{array}$ & 5,572 & WHO 1996-2014 \\
\hline Burundi & 17,542 & WHO 1996-2014 \\
\hline Cameroon & 59,876 & WHO 1996-2014 \\
\hline $\begin{array}{l}\text { Cape- } \\
\text { Verde }\end{array}$ & 561 & WHO 1996-2014 \\
\hline Centeral African Republic & 923 & WHO 1996-2014 \\
\hline Chad & 57,260 & WHO 1996-2014 \\
\hline Côte d'Ivoire & 15,635 & WHO 1996-2014 \\
\hline Comoros & 15,130 & WHO 1996-2014 \\
\hline Equatorial Guinea & 6,450 & WHO 1996-2014 \\
\hline Ethiopia & 113,080 & WHO 1996-2014 \\
\hline Eritrea & 120 & WHO 1996-2014 \\
\hline $\begin{array}{l}\text { Democratic Republic } \\
\text { of the Congo } \\
\text { (Previously named Zaire till 1997) }\end{array}$ & 285,335 & WHO 1996-2014 \\
\hline Congo & 18,472 & WHO 1996-2014 \\
\hline Djibouti & 7,085 & WHO 1996-2014 \\
\hline Gabon & 630 & WHO 1996-2014 \\
\hline Gambia & 249 & WHO 1996-2014 \\
\hline Ghana & 57,690 & WHO 1996-2014 \\
\hline Guinea & 34,548 & WHO 1996-2014 \\
\hline Guinea-Bissau & 74,150 & WHO 1996-2014 \\
\hline Kenya & 76,203 & WHO 1996-2014 \\
\hline Libya & 22 & WHO 1996-2014 \\
\hline Liberia & 63,041 & WHO 1996-2014 \\
\hline Madagascar & 46,084 & WHO 1996-2014 \\
\hline Malawi & 82,972 & WHO 1996-2014 \\
\hline Mayotte & 12 & WHO 1996-2014 \\
\hline Mali & 10,233 & WHO 1996-2014 \\
\hline Mauritania & 9,316 & WHO 1996-2014 \\
\hline $\begin{array}{l}\text { Mozambique } \\
\text { (Beira) }\end{array}$ & NR & Deen et al., 2008 \\
\hline Mozambique & 229,660 & WHO 1996-2014 \\
\hline Namibia & 9,141 & WHO 1996-2014 \\
\hline Niger & 19,719 & WHO 1996-2014 \\
\hline Nigeria & 40,000 & Oladele et al., 2012 \\
\hline Nigeria & 59,478 & Oladele et al., 2012 \\
\hline Nigeria & 119,556 & WHO 1996-2014 \\
\hline Rwanda & 7,769 & WHO 1996-2014 \\
\hline Sao Tome and Principe & 3,101 & WHO 1996-2014 \\
\hline Senegal & 58,291 & WHO 1996-2014 \\
\hline Seycells & 178 & WHO 1996-2014 \\
\hline Sierra Leone & 42,076 & WHO 1996-2014 \\
\hline Somalia & 223,060 & WHO 1996-2014 \\
\hline South Africa & 160,509 & WHO 1996-2014 \\
\hline Sudan & 58,074 & WHO 1996-2014 \\
\hline Swaziland & 7,112 & WHO 1996-2014 \\
\hline
\end{tabular}




\begin{tabular}{lcc}
\hline \multicolumn{1}{c}{ Area } & Incidence $^{\mathbf{a}}$ & Reference $^{-}$ \\
\hline $\begin{array}{l}\text { Uganda } \\
\text { (Kampala city) }\end{array}$ & $\begin{array}{c}\text { 6,228 in which 1,091 were } \\
\text { children under five years of } \\
\text { age }\end{array}$ & Legros et al., 2000 \\
United Republic & & \\
of & 5,028 & WHO 1996-2014 \\
Tanzania & & \\
Togo & 12,097 & WHO 1996-2014 \\
Uganda & 96,966 & WHO 1996-2014 \\
Zambia & 55,087 & WHO 1996-2014 \\
Zimbabwe & 144,982 & WHO 1996-2014
\end{tabular}

${ }^{a}$ Incidence: number of cases reported during the specific years of the data collection 1995 to 2013 unless otherwise noted; 'WHO (1996; WHO,1997;WHO, 1998; WHO, 1999; WHO, 2000; WHO, 2001; WHO, 2002; WHO, 2003; WHO, 2004; WHO, 2005; WHO, 2006; WHO, 2007; WHO, 2008; WHO, 2009; WHO, 2010; WHO, 2011; WHO, 2012; WHO, 2013; WHO, 2014); ' Microorganism V. cholerae 01 and O139, Prevalence 4.0 E-03, Period of Study December 2003 to January 2004 ; ${ }^{\mathrm{d}}$ Microorganism V. cholerae O1 El Tor, serotype Ogawa, Period of Study is December, 1997 to March, 1998.

Table 3. Incidence of $V$. cholerae in Asian countries from 1995 to 2013

\begin{tabular}{|c|c|c|}
\hline Area & Incidence $^{\mathrm{a}}$ & Reference \\
\hline Afghanistan & 82,853 & WHO 1996-2014 \\
\hline Armenia & 25 & WHO 1996-2014 \\
\hline Bangladesh & 0 & WHO 1996-2014 \\
\hline Bhutan & 44 & WHO 1996-2014 \\
\hline Brunei Darussalam & 96 & WHO 1996-2014 \\
\hline Cambodia & 8,677 & WHO 1996-2014 \\
\hline China & 20,711 & WHO 1996-2014 \\
\hline Democratic Republic of Timor & 30 & WHO 1996-2014 \\
\hline East Timor & 581 & WHO 1996-2014 \\
\hline Hong Kong & 168 & WHO 1996-2014 \\
\hline $\begin{array}{l}\text { India }^{\mathrm{c}} \\
\text { (Kolkata) }\end{array}$ & NR & Deen et al., 2008 \\
\hline India & 61,972 & WHO 1996-2014 \\
\hline $\begin{array}{l}\text { Indonesia }^{\mathrm{d}} \\
\text { (Jakarta) }^{2}\end{array}$ & NR & Deen et al., 2008 \\
\hline Indonesia & 2,411 & WHO 1996-2014 \\
\hline Iraq & 9,639 & WHO 1996-2014 \\
\hline Iran & 7,630 & WHO 1996-2014 \\
\hline Israel & 1 & WHO 1996-2014 \\
\hline Japan & 812 & WHO 1996-2014 \\
\hline Kazakhstan & 14 & WHO 1996-2014 \\
\hline Kuwait & 1 & WHO 1996-2014 \\
\hline Lao Peoples Democratic Republic & 14 & WHO 1996-2014 \\
\hline Lebanon & 1 & WHO 1996-2014 \\
\hline Macoo & 8 & WHO 1996-2014 \\
\hline Malaysia & 6,407 & WHO 1996-2014 \\
\hline Magnolia & 177 & WHO 1996-2014 \\
\hline Myanmar & 1,564 & WHO 1996-2014 \\
\hline Nepal & 4,609 & WHO 1996-2014 \\
\hline
\end{tabular}




\begin{tabular}{lcc}
\hline Area & Incidence $^{\mathbf{a}}$ & Reference \\
\hline Oman & 12 & WHO 1996-2014 \\
Pakistan & 1,904 & WHO 1996-2014 \\
Philippines & 8,321 & WHO 1996-2014 \\
Qatar & 2 & WHO 1996-2014 \\
Republic of Korea & 246 & WHO 1996-2014 \\
Saudi Arabia & 38 & WHO 1996-2014 \\
Singapore & 132 & WHO 1996-2014 \\
Sir Lanka & 2,085 & WHO 1996-2014 \\
Thailand & 4,504 & WHO 1996-2014 \\
Turkmenistan & 55 & WHO 1996-2014 \\
United Arab Emirates & 3 & WHO 1996-2014 \\
Vietnam & 5,624 & WHO 1996-2014 \\
Yemen & 32,144 & WHO 1996-2014
\end{tabular}

${ }^{a}$ Incidence: number of cases reported during the specific years of the data collection; ${ }^{b} \mathrm{WHO}$ (1996; WHO,1997;WHO, 1998; WHO, 1999; WHO, 2000; WHO, 2001; WHO, 2002; WHO, 2003; WHO, 2004; WHO, 2005; WHO, 2006; WHO, 2007; WHO, 2008; WHO, 2009; WHO, 2010; WHO, 2011; WHO, 2012; WHO, 2013; WHO, 2014); ${ }^{\circ}$ Microorganism is V. cholerae O1 and O139, Prevalence 1.6 E-03, Period of Study May, 2003 to April, 2005; ${ }^{\mathrm{d}}$ Prevalence 5.0 E-04, Period of Study August, 2001 to July, 2003

An estimated 3,907,290 cases of cholera outbreaks were reported between 1995 and 2013 globally (WHO, 2014). The most affected continent was Africa, with a rate of $68.90 \%$ of global outbreaks, followed by America, with $23.50 \%$, and Asia, with $7.05 \%$. The least affected continents were Oceania $(0.41 \%)$ and Europe $(0.04 \%)$. Moreover the global number of deaths was 96030 cases of which $85.12 \%$ were reported in Africa, followed by $11.36 \%$ in the Americas and then 3.30, 0.17 and $0.02 \%$ in Asia, Oceania and Europe, respectively. After several years of steady increase (since 2007), the number of cholera cases reported to WHO, as well as the number of countries, which reported cholera cases, showed an important decrease in 2012 compared to 2011 in which the highest outbreaks was observed especially in Americans continent (WHO, 1996 to 2013).

In 2016, 38 countries reported a total of 132,121 cases of cholera including 2,420 deaths, giving a case fatality rate (CFR) of $1.83 \%$. This represents a decrease of $22 \%$ compared to the number of cases $(589,854)$ reported by 58 countries in 2011 and this is the second consecutive year in whch there was a decline in reported cholera cases (WHO, 2012; 2017). Overall, Ali and co-workers estimated the global burden of cholera between 1.4 and 4.3 million cases, and between 28,000 and 142000 deaths per year (Ali et al.,
2012).

Using a multivariable spatial regression model, Ali and co-workers (2015) defined the status of a country as endemic, non-endemic or cholera free (Figure 3). This model predicted 1.3 billion people at risk for cholera in the 69 countries classified as cholera-endemic areas and another 99 million persons in the three countries (i.e., Bolivia, Pakistan, and Sri Lanka) at risk for non-endemic areas between 2008 and 2012. These authors pointed out that over ten million persons at risk of cholera resided in 23 endemic countries. The highest number of people at risk for cholera was found in India, Nigeria, China, Ethiopia and Bangladesh. Annually, estimates of more than 100,000 cases countries were found in India, Ethiopia, Nigeria, Haiti, the Democratic Republic of the Congo, Tanzania, Kenya, and Bangladesh. As can be seen in Figure 3, cholera remains a major public health problem in many countries in sub-Saharan Africa compared to the rest of the world. In endemic countries, Ali et al., (2015) highlighted that cholera resulted in approximately 95,000 deaths, figures that translate to approximately 7.50 deaths $/ 100,000$ population at risk per year in endemic countries. The countries with more than 1,000 deaths due to cholera annually, are found in the African region with the exception of India, Bangladesh, and Haiti (AMR). 


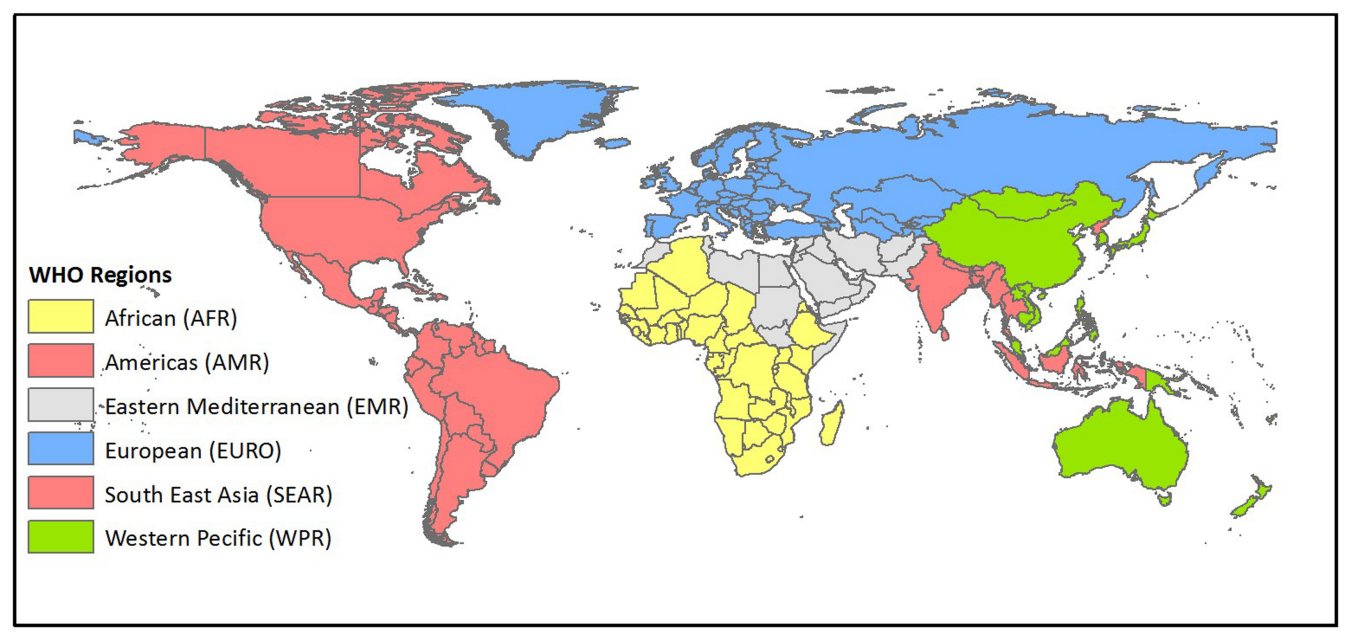

Figure 3. Number of cholera cases reported annually in endemic countries (Source: Ali et al., 2015)

An epidemiological update of cholera outbreaks in selected countries of sub-Saharan Africa between 1994 and 2016 also highlighted the persistence of this disease in the region in spite of the decrease in case numbers that occurred in some countries (Table 4) (UNICEF, 2016).

Table 4. Epidemiological update of cholera outbreaks in selected countries of sub-Sahara African countries between 1994 and 2016 (UNICEF, 2016).

\begin{tabular}{|c|c|c|c|c|c|}
\hline \multirow{2}{*}{$\frac{\text { Area }}{\text { Benin }}$} & \multicolumn{2}{|c|}{ Cases: 1994-2013 } & \multirow{2}{*}{$\begin{array}{c}\text { Cases in } \mathbf{2 0 1 4} \\
874\end{array}$} & \multirow{2}{*}{$\begin{array}{c}\text { Cases in } 2015 \\
00\end{array}$} & \multirow{2}{*}{$\begin{array}{c}\begin{array}{c}\text { Cases in } \\
\mathbf{2 0 1 6}\end{array} \\
874\end{array}$} \\
\hline & 2004 to 2013 & 5,432 & & & \\
\hline Cameroun & 2004 to 2013 & 46,172 & 3,355 & 120 & 77 \\
\hline Côte d'Ivoire & 2002 to 2013 & 7,573 & 248 & 200 & 16 \\
\hline Democratic Rep Congo & $N^{a}$ & NR & 19,305 & 18,403 & 28,162 \\
\hline Ghana & 1998 to 2013 & 5,432 & 28,944 & 687 & 600 \\
\hline Guinea Bissau & 1996 to 2013 & 74,031 & 18 & 00 & 00 \\
\hline Lake Chad Basin & 2004 to 2013 & 31,918 & 41,188 & 6,084 & 883 \\
\hline Niger & 1994 to 2013 & 21,538 & 2,059 & 51 & 38 \\
\hline Nigeria & 2004 to 2013 & 105,483 & 35,996 & 5,913 & 768 \\
\hline Togo & 2006 to 2013 & 2,142 & 329 & 50 & 02 \\
\hline
\end{tabular}

${ }^{a}$ NR: Not Reported

In the Democratic Republic of Congo, Siddique et al., (1995) reported a deadliest cholera epidemics in a refugee camps located around Goma and Bukavu. This explosive outbreak of cholera resulted in approximatively 70,000 cases and 12,000 deaths. In 2017, this country experienced an impressive outbreak that originated from North Kivu province, affecting mainly Goma, Karisimbi, Nyirango and
Binza. This resulted in a total of 15,456 suspected cases including 441 deaths (UNICEF, 2017). During the week 26 of the same year, 186 suspected cholera cases including 10 deaths were also reported in Nigeria by UNICEF (2017). 
1.1.2 Symptomatology [morbidity and case fatality rates (CFRs)]

It is an ancient and devastating acute diarrheal disease caused by toxigenic $V$. cholerae. This bacterium infects only humans and other primates. Vibrio cholerae causes a spectrum of infections in both adults and children ranging from asymptomatic colonization to severe and rapidly fatal secretory diarrhoea known as cholera gravis. Although diarrhea is a common symptom for various enteropathogenic microorganisms (e.i viruses, bacteria and protozoan parasites) or the body's reaction to bad food, it results in a dangerous loss of fluids in the case of cholerarelated diarrhea. Generally, the cholera-related diarrhea is of a watery consistency, and presents a pale milky appearance, which can occur very suddenly and can lead to various complications. The infection by non-O1 and nonO139 is also characterized by diarrhea, with acute abdominal cramps, and fever in sever cases where this disease is self limiting and controlling in most of the cases.

As can be seen in Figure 4, at least one cholera case was reported between 1995 and 2016 in all the five continents of the world. The WHO's reports during this period also provide the estimated outbreak cases, number of death cases and (CFRs) for each of these continents, with a rising evidence of the large and growing burden of cholera in Africa (Table 1A). Total cholera outbreaks in over all five continents (Africa, Americas, Asia, Europe and Oceania) during 21 years between 1995 and 2016 resulted in $4,407,445$ cases and the total cholera deaths of 62,865 with CFR (1.42\%) (Tables $1 \mathrm{~A}$ and $1 \mathrm{~B})$.

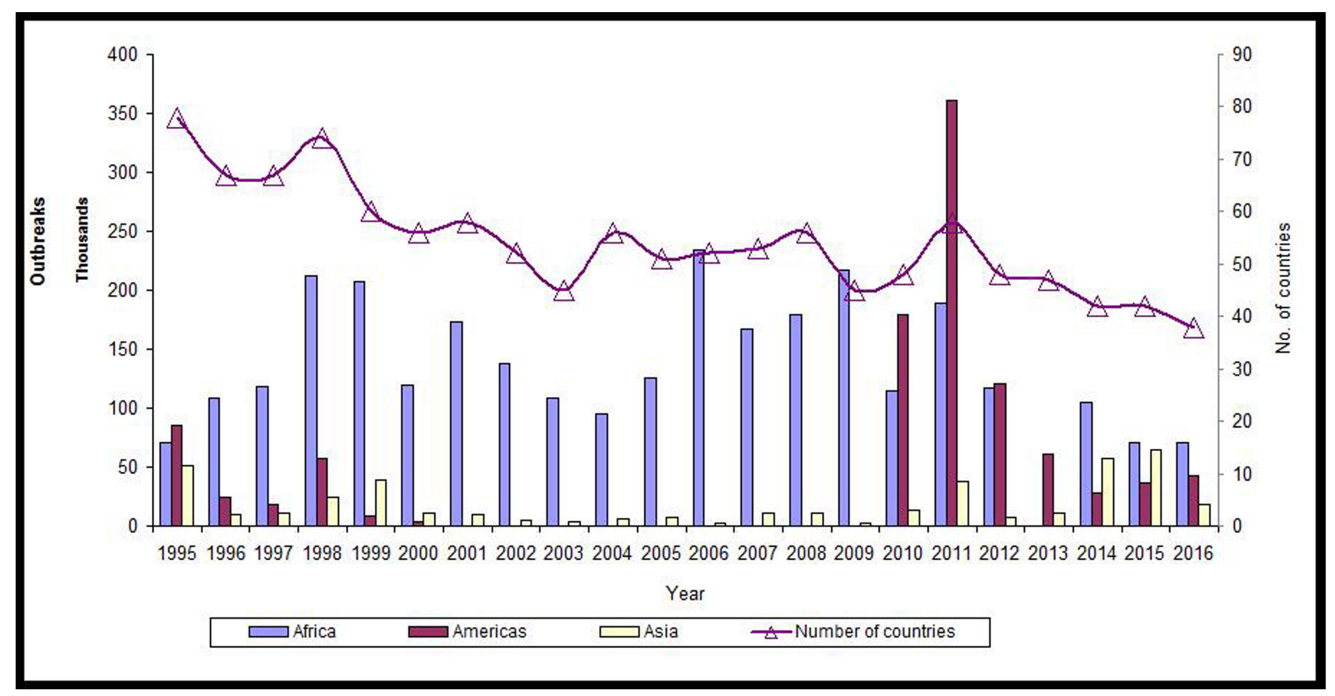

Figure 4. Number of cholera cases in Africa, Americas and Asia and global number of countries containing even at least one cholera outbreak case during the period extended from 1995 to 2016 (Adapted from WHO, 1996-2017).

In 2015,42 countries reported a total of 172,454 cases including 1,304 deaths, resulting in an overall case fatality ratio (CFR) of $0.8 \%$. Cases were reported from all regions, including 16 countries in Africa, 13 in Asia, six (6) in Europe, six (6) in the Americas, and one (1) in Oceania. Afghanistan (no. of cases 58,064), the Democratic Republic of the Congo (DRC) (no. of cases 19,182), Haiti (no. of cases 36,045 ), Kenya (no. of cases 13,291), and the United Republic of Tanzania (no. of cases 11,563) accounted for $80 \%$ of all cases. Of cases reported globally, $41 \%$ were from Africa, 37\% from Asia and 21\% from Hispaniola. Imported cases were reported from 13 countries (WHO, 2016).

In 2016, 38 countries reported a total of 132,121 cases including 2,420 deaths, resulting in an overall case fatality rate (CFR) of $1.8 \%$. Cholera was reported from countries in all regions: 17 countries in Africa, 12 in Asia, four (4) in the Americas, four (4) in Europe and one (1) in Oceania. Five countries - the Democratic Republic of the Congo (DRC) (no. of cases 28,093), Haiti (no. of cases 41,421 ), Somalia (no. of cases 15,619), the United Republic of Tanzania (no. of cases 11,360) and Yemen (no. of cases 15,751) - together accounted for $80 \%$ of all cases. Of cases reported globally, $54 \%$ were from Africa and 13\% from Asia (WHO, 2017). In 2017 , the most recent cholera outbreaks were observed in Yemen between April and August months. The total suspected cholera cases were 503,484 and the death cases were 1,975 with CFR 0.4\% (EWARS, 2017).

Total cholera outbreak cases in Africa between the year 1995 and 2016 were estimated to be 2,941,788 case with a total of 86,330 death cases (CFR 2.93\%). The highest outbreak cases of 234,349 (CFR 2.66\%) were recorded in 2006, followed by 217,333 cases (CFR 2.24\%), 211,748 cases (CFR 3.61\%) and 206,746 cases (CFR 3.60\%) recorded in 2009, 1998 and 1999, respectively. In the sub- 
Saharan Africa, the highest cholera outbreak that was recorded in South Africa in 2001 reached a total of 106,151 cases, followed by Angola in 2006 with a total of 68,257 cases. Nigeria also reported a high cholera outbreak that reached a total of 44,456 cases (CFR 3.85\%) (WHO, 1996-2017).

In the American continent, the highest number of cases was recorded in 2011 with a total number of 361,266 cases (CFR $0.89 \%$ ), followed by 2012 with a total of 120,433 cases (CFR 0.80\%). In Haiti, since the beginning of the epidemic in October 2010 and until December 2013, 696,794 cholera cases were reported, of which 389,903 individuals were hospitalized (56\%) and 8,531 died (CFR $1.22 \%)$. The CFR ranged from $4.4 \%$, in the Department of "Sud Est" to 0.6\% in Port-au-Prince. During 2013, 58,809 cases including 593 deaths were reported (CFR 1\%), which shows a $47 \%$ decrease compared to the cases reported in $2012(112,076)$. In 2016, this country struggled with the hurricane Matthew, which resulted in almost 27,000 cholera cases and 240 deaths according to the UN's Central Emergency Response Fund (UN, 2016). Between 2010 and 2016, cholera has plagued at least 770,000 Haitians and caused over 9,200 lives. The cholera epidemic in Haiti alone resulted in an increase of $85 \%$ in the number of cholera cases worldwide. The second highest outbreak was recorded in Peru in 1995 and 1998 with a total number of cases of 22,337 and 41,717 , respectively. In Peru, the second highest outbreak was recorded in 1995 and 1998 with total cases of 22,337 and 41,717 , respectively (WHO, 2016).

In Asia the highest numbers were recorded in 1995 with a total of 50,921 cases (CFR 2.24\%) and in 2010 with a total of 13,819 cases (CFR $0.434 \%$ ), while these numbers increased to 56,787 cases in 2014 (CFR 0.07\%) and 64,590 cases (CFR 0.05\%) in 2015 (Table 1; Figure 4) (WHO, 1996-2017).

\subsection{Taxonomic classification of Vibrio cholerae}

Vibrio cholerae is a curved Gram-negative, facultative anaerobic, rod-shaped, non-spore-forming bacterium, which is highly motile with either unipolar or bipolar flagella, that belongs to the family Vibrionaceae and shares common characteristics with the family Enterobacteriaceae (Baumann and Baumann, 1984).

Vibrio cholerae is not homogeneous and can include over 200 serogroups based on its $\mathrm{O}$ antigen (Shimada et al., 1994; Yamai et al., 1997). Of all these serogroups only serogroups 01 and 0139 are able to cause cholera epidemics or pandemics. As stated above, the non-O1 and O139 serogroups are rarely associated with human infections, causing mild gastroenteritis or septicaemia (West, 1989; Powell, 1999). Figure 5 illustrates V. cholerae and its biotypes and serotypes.

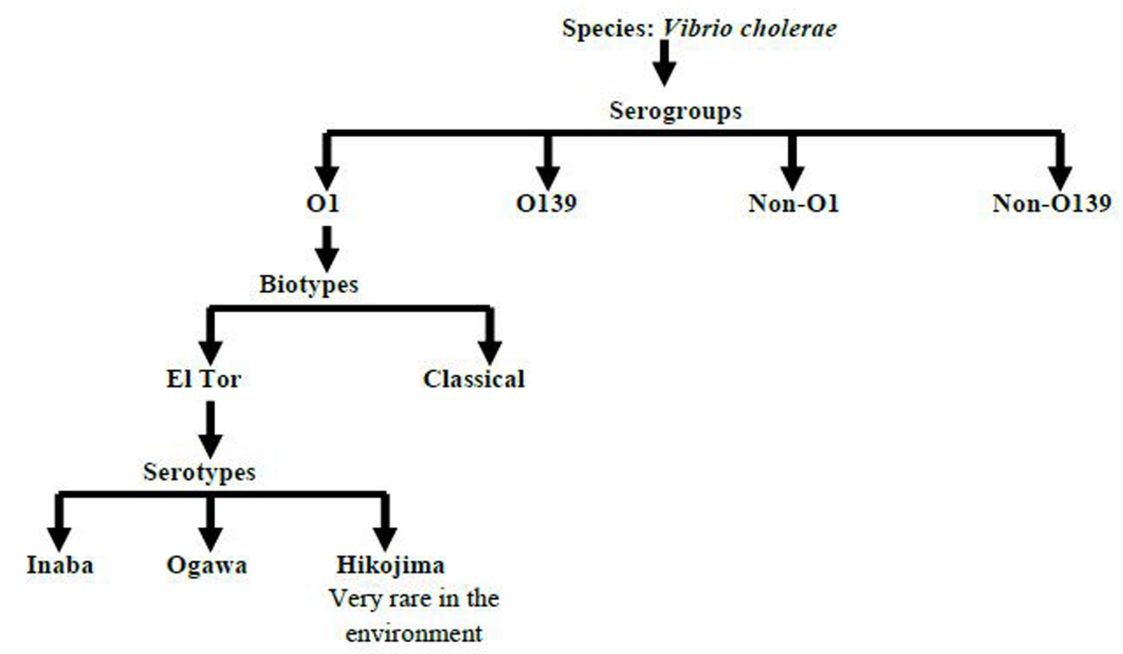

Figure 5. Schematic diagram illustrating V. cholerae, their biotypes and serotypes

Vibrio cholerae 01 and 0139 serogroups are extremely similar in the composition of the lipopolysaccharides (LSP) (Hisatsune et al., 1993; Isshiki et al., 1996). The most notable differences between $V$. cholerae serogroups $\mathrm{O} 1$ and $\mathrm{O} 139$ are the lengths and composition of the $\mathrm{O}$ side chains of the cell-wall LPS. Unlike $V$. cholerae O1, which has long O-polysaccharide side chains, the LPS of $V$. cholerae 0139 contains only short O-antigen side chains (Knirel et al.,
1997).

Epidemologically, biotyping is viewed as an important classification method for $V$. cholerae 01 strains. There are two biotypes of V.cholerae serogroup 01, classified on the basis of various phenotypic and genotypic markers, namely classical and El Tor, and three serotypes: Ogawa, Inaba and Hikojima (Kaper et al., 1995; Faruque et al., 2007b). The 
most prevalent serotype is Ogawa, while Hikojima is very rare and unstable in the environment. The differences between the classical and El Tor biotypes of V. cholerae 01 are as follows:

- El Tor possesses better adaptability to subsist in the environment and in the human host as they are better able to colonize the intestinal epithelium than the classical biotype (Finkelstein, 1996).

- However, the $V$. cholerae 01 classical biotype is suggested to be more toxigenic and virulent than El Tor (Huq et al., 1983; Koelle et al., 2005a).

- In terms of phenotype disparities, El Tor is sensitive to both Mukerjee El Tor phage 5 and 50 IU of polymycin $B$, while the classical biotype is sensitive to Mukerjee Classical phage IV. In addition to these, the El Tor biotype is agglutinated by chicken erythrocytes and gives a positive Voges-Proskauer test reaction while the classical biotype does not (Mandal et al., 2011).

Vibrio cholerae $\mathrm{O} 1$ classical (CL) biotype is assumed to be the main causative agent of the first six cholera pandemics, resulting in both symptomatic and asymptomatic cases. Thereafter it became extinct and the seventh and current cholera pandemics have been associated with the El Tor biotype, which first appeared in 1905 in the village of El Tor, Sinai, Egypt and caused more asymptomatic infections than any other biotype. With the current development, altered $V$. cholerae $01 \mathrm{El}$ Tor isolates produce cholera toxin of the classical biotype, but can be biotyped as El Tor by conventional phenotypic assays. The O139 serogroup (synonym: Bengal) is contained on different genetically-diverse strains, both toxigenic and non-toxigenic; it is genetically closer to El Tor V. cholerae (Ansaruzzaman et al., 2004).

The three Ogawa, Inaba and Hikojima serotypes are actually different, depending on their antigenic structures and are classified in terms of their somatic $(O)$ antigen. The Ogawa serotype has A and B antigens, the Inaba serotype has $\mathrm{A}$ and $\mathrm{C}$ antigens, while Hikojima has unstable antigenic types containing all three antigens (A, B and C). The Ogawa and Inaba serotypes are positive for Ogawa and Inaba antisera, respectively. Hikojima serotype is positive for both Ogawa and Inaba antisera (Shimada et al., 1994; Mandal et al., 2011).

Choleragenic $V$. cholerae are characterized by their ability to produce cholera toxin (CT) that is encoded by the ctx gene (Kaper et al., 1995). The first island, chosen CT, is a 7000-9700 bp region encoding no less than six genes (Waldor and Mekalanos, 1996; Mekalanos et al., 1997). The foremost of these gene products is CT, an oligomeric protein (MW 84,000) comprising five B subunits $(\operatorname{ct} \times B)$ and one A subunit ( $\operatorname{ct} x A$ ). The B subunit binds holotoxin to the host cell receptor, while the A subunit is responsible for toxigenic activity intracellularly after proteolytic cleavage into 2 peptides, A1 and A2. The internal activation of the A1 peptide results in ADP-ribosyltransferase activity, which leads to the change of ion transport and hyper-secretion of water and $\mathrm{Cl}$ into the lumen of the intestine.
In recent years, there are emergence of new pathogenic variants of $V$. cholerae, which exhibit a combination of phenotypic and genotypic traits from the Classical and El Tor biotypes and were classified as hybrid biotype (Asish et al., 2014). The rise and spread of these variants has been reported throughout many countries, especially in Asia (NaUbol et al., 2011; Tran et al., 2012) and Africa (Ceccarelli et al., 2011, Naha et al., 2013) as well as in Mexico (Alam et al., 2012). They include the Matlab (MT) variant from Bagladesh (Nair et al., 2002) and the Mozambic variants, an atypical El Tor strain harbouring CTX $\phi$ Cla (Faruque et al., 2007b, Das et al., 2007). Similar strains carrying tandem copies of СТХ $\Phi$ Cla in the small chromosome or in large chromosome have been also isolated in other parts of world (Nair et al., 2006; Nguyen et al. 2009). The Haitian variant of the $\mathrm{El}$ Tor biotype contains a unique mutation at the 58th nucleotide of ctxB (the gene for the B subunit of cholera toxin) (Nair et al., 2006). This strain has completely replaced the El Tor biotype on Kolkata, dia since 1995 (Raychoudhuri et al., 2009). The Haitian V. cholerae strain also had a novel mutation at the $64^{\text {th }}$ amino acid position of the matured TcpA subunit (Naha et al., 2012; Ghosh et al. 2014). Extensive reviews and studies on numerous aspects of the cholera toxin are currently available (Kaper et al., 1995; Sears and Kaper, 1996; Scott et al., 1996; Reidl and Kiose, 2002; Edwards and March, 2007; Chen et al., 2008; Ghosh-Banerjee et al., 2010; Maheshwari et al., 2011).

\subsection{Transmission}

Cholera disease is usually transmitted by ingestion of food or water contaminated directly or indirectly by the excretions of infected people, e.g. faeces or vomit (Tauxe and Blake, 1992; Rabbani and Greenough, 1999). In historical treaties on cholera, seaborne transport of cholera provides the fundamental theory of propagation. However, early records show an association with contaminated water, rivers or swampy areas, or marshes where the streams were much reduced (Colwell, 1996). Cholera infects only humans and always transmits by fecal oral route; there is no insect vector or animal reservoir hosts (WHO, 2010a), but $V$. cholerae is able to accumulate in zooplankton, which are fed-upon by oysters (Colwell, 2013).

\subsubsection{Routes of transmission}

Two main transmission routes of $V$. cholerae have been documented. The first and primary route is via the aquatic environment, and the second route occurs when the infection is transmitted from infected to healthy people by water or food contamination (Ruiz-Moreno et al., 2010). Once the primary transmission has initiated an outbreak, the secondary transmission causes epidemics in the endemic areas.

In endemic areas, the aquatic environment is the main route of transmission for cholera disease. Cholera is usually transmitted by ingestion of drinking water contaminated with sewage (Tauxe and Blake, 1992). Sewage contamination of groundwater in Delhi was responsible for the epidemic of $V$. cholerae (Pathak et al., 1993). In Haiti in 
2010, cholera infection was documented along the Artibonite River (Barzilay et al., 2013, Gaudart et al., 2013). Several studies have reported the isolation and detection of Vibrio species and $V$. cholerae from a variety of aquatic environments, including drinking water (Blake et al., 1977; Ries et al., 1992; Shapiro et al., 1999; Downs et al., 1999), freshwater (Hughes et al., 1982; Grim et al., 2010; Madoroba and Momba, 2010; Rashid et al., 2013), wastewater (Momba et al., 2006; Igbinosa et al., 2009; Nongogo and Okoh, 2014), brackish water (Reilly and Twiddy, 1992; El-Lathy, 2009), and sea water (Colwell et al., 1977; 1981; Lipp et al., 2003; Gazi et al., 2010; Rashid et al., 2013). There is a relationship between $V$. cholerae and planktonic crustacean copepods, which leads to the contamination of water. Hug and co-workers (1983) have pointed out that several copepods with $V$. cholerae cells attached to the surface and in the gut may contain up to $10^{4}$ cells of $V$. cholera, a concentration, which is the prerequisite infectious dose for clinical cholera. During a plankton bloom, these copepods may be ingested in a glass of water if this water is not subjected to any treatment. This may increase the chances of consuming water contaminated with $V$. cholerae.

Another route of cholera transmission during interepidemic periods via water environments is horizontal transfer of virulent genetic matter from non-predominant toxigenic $V$. cholerae to predominant non-toxigenic $V$. cholerae. This may occur in both $V$. cholerae $\mathrm{O} 1$ and non01, which survive in the same water environments, whereas non-toxigenic $V$. cholerae non-O1 predominates over toxigenic $\mathrm{O} 1$ bacteria. In some unfavourable conditions and as a result of lysogeny and horizontal gene transfer, the genetic material such as cholera toxin (CTX) gene and other virulence factors have been reported to be transferred to non-toxigenic $V$. cholerae (Faruque et al., 2004; Valdespino and Garcĺa-Garcĺa, 2011).

Cholera diseases are able to spread via food, and thus infection due to $V$. cholerae begins with the ingestion of contaminated water or food. Transmission of cholera in non-endemic areas is more frequently associated with consumption of foods, such as raw or undercooked sea food, imported from cholera-endemic areas (Mandal et al., 2011). In many countries, consuming contaminated uncooked vegetables and seafood is a long-standing source of cholera outbreaks. Vegetables are possibly contaminated during pre- and post-harvest due to irrigation or wash waters contaminated with $V$. cholerae (Wachsmuth et al., 1994; Faruque et al., 1998; Anon, 2000). Fruits, vegetables, sea food, fish, shellfish, crabs and oysters, even poultry, red meat and dairy products may play a vital role in the transmission of cholera in many areas (Maheshwari et al., 2011). Fish samples from fresh and marine waters carry $V$. cholerae and it has been reported that fish intestines contain $V$. cholerae counts of up to $5.0 \times 10^{3} \mathrm{CFU} / \mathrm{g}$ (Senderovich et al., 2010).

Cholera may also be transmitted by an additional route; it is transported over long distances by human migration. It has been suggested that $V$. cholerae may have re-entered South America in 1991, after a century of absence, from the bilge and ballast water of cargo ships (WHO, 2003a).

\subsubsection{Reservoirs}

Asymptomatically infected people having sub-clinical doses of $V$. cholerae are some of the main reservoirs of cholera. Once conditions are favourable, those people are able to spread the disease. The aquatic environments can also be a reservoir for Vibrio cholerae even in the absence of outbreaks (Akoachere and Mbuntcha, 2014). Since the nineteenth century, the physician Snow recognized that water acts as a reservoir for cholera diseases and that $V$. cholerae is able to spread by infected water (Shears, 1994). Recently many researchers have confirmed that the different water sources are able to serve as a reservoir for $V$. cholerae and responsible for spreading cholera disease (Colwell and Huq, 1994; Shapiro et al., 1999; Blokesh and Schoolnik, 2007). Akoachere and Mbuntcha (2014) investigated well-, tap- and stream-water samples in Bepanda, Cameroon, as reservoirs of Vibrio cholerae; they found that $33 \%$ of 96 isolates were confirmed as $V$. cholerae 01.

Available literature suggests that fish act as reservoirs of $V$. cholerae. Cholera has been associated with consumption of fish in several countries: India (Pandit and Hora, 1951), Germany (Schürmann et al., 2002), Japan (Kiiyukia et al., 1992), Thailand and Srilanka (Plesnik and Prochazkova, 2006), Tanzania (Acosta et al., 2001), and Peru (Carvajal et al., 1988). Numerous reports (Huq et al., 1983; Dumontet et al., 1996; Bhaskar et al., 2004; Halpern et al., 2004; Jeffs et al., 2004) have pointed out that macroalgae, seafood, and marine crustaceans such as copepods and chironomid egg masses act as environmental reservoirs of $V$. cholerae. Wakeham et al. (1997) suggested that the sediment of the equatorial Pacific Ocean is another environmental reservoir of $V$. cholerae.

\subsubsection{Incubation period}

The incubation period is usually very short and ranges from $2 \mathrm{~h}$ to 5 days. After a typical incubation period of 1 to 2 days, there can be an extended period up to 5 days in some cases; the infected people experience a sudden onset of watery diarrhoea. Vomiting is common and often precedes the onset of diarrhoea with fluid loss often 500 to 1,000 $\mathrm{mL} / \mathrm{h}$, leading to severe dehydration. Over a $24 \mathrm{~h}$ period, up to 20 litres of watery diarrhoea can be excreted in adults. If left untreated, the mortality rate may reach 40 to $60 \%$ (Speck, 1993; Sack et al., 2004; WHO, 2009a). The stool of the infected people became highly infectious containing high counts of choleragenic $V$. cholerae up to $10^{9} \mathrm{CFU} / \mathrm{mL}$ of stool (Dizon et al., 1967). Without antibiotic treatment, organisms are secreted in the stool for an average of 6 days (Lindenbaum et al., 1967). The incubation period for noncholeragenic Vibrio spp. infection is usually $12 \mathrm{~h}$ to 3 days, but can be extended for up to one week (Seas and Gotuzzo, 2009).

\subsubsection{Period of communicability}

After ingestion, $V$. cholerae colonizes the small intestine for 12 to 3 days asymptomatically. Then the symptoms of cholera begin to appear with stomach cramps and vomiting 
followed by diarrhoea, which may progress to fluid losses up to $1 \mathrm{~L} / \mathrm{h}$. Rice water stools of the infected people can carry Vibrio cholerae counts ranging between $10^{10}$ and $10^{12}$ CFU/L (Phillips, 1964; Nelson et al., 2009).

Symptomatic patients may shed $V$. cholerae before the onset of illness (Cash et al., 1974) and will continue to shed those organisms for 1 to 2 weeks (Kaper et al., 1995). The minimum infective dose of $V$. cholerae is about $10^{3}$ cells (Bitton, 2005). Asymptomatic patients typically shed Vibrio organisms in their stool for only one day, at approximately $10^{3} \mathrm{CFU} / \mathrm{g}$ of stool (Mosley et al., 1968; Nelson et al., 2009). Therefore, the distribution of symptomatic patients influences the quantity of $V$. cholerae that is shed for subsequent transmission. The infected people who have not received any antibiotics for treatment may be continuously shedding Vibrio cholerae for one to two weeks. Less than $1 \%$ of patients continue shedding the organisms in their faeces for extended time periods, in some cases reaching up to 10 years and have positive stool cultures for Vibrio cholerae after an initial case of cholera (Azurin et al., 1967; Dizon, 1974; Kaper et al., 1995).

\subsubsection{Population susceptibility}

Historically, $V$. cholerae infection has had a profound effect on human populations, including their evolution and cultural development. It is important to note that the susceptibility to cholera depends on a number of factors, which include local intestinal immunity from previous exposure or vaccination, bacterial load and intrinsic host factors such as stomach $\mathrm{pH}$ (gastric acid providing a barrier) and blood group (Sack et al., 2004).

In general, exposure to $V$. cholerae through contaminated drinking water or food products such as undercooked seafood can lead to cholera infection in any population category, while immuno-compromised individuals, elderly people and children at the highest risk. Risk factors for the disease include poor sanitation, not enough clean drinking water, and poverty. Sporadic outbreaks can be due to contamination of drinking water and food in highly populated areas harbouring endemic toxigenic $V$. cholerae. Water sources contaminated with $V$. cholerae are probably the main origin of epidemics, followed to a lesser extent by contaminated food, especially seafood products like oysters, crabs, and shellfish (Kaysner and Hill, 1994). Drinking unboiled or untreated water is a risk factor for cholera, while the use of soap is typically associated with a lower likelihood of infection ( $\mathrm{O}^{\prime}$ Connor et al., 2011). In food-borne outbreaks, the risk factors may include consumption of specific contaminated foods, such as rice products, vegetables or fruits (Rabbani and Greenough, 1999). In regions where cholera is sporadic, for example in the United States, most cases are linked to consumption of undercooked shellfish including oysters.

Displacing large populations and the collapse of infrastructure, associated with natural disasters and intensified by climate change, provide an ideal ground for cholera (HolNAer et al., 2010). Climate variability has been assumed to have the ability to directly influence the outbreaks of infectious diseases, such as cholera. A long- term study on El Tor cholera in Matlab, Bangladesh that spanned a period of four decades has established such a correlation (Koelle et al., 2005b).

Recently, Bavishi and Dupont (2011), found that the other risk factors for cholera infection are related to specific biological interactions between host and pathogen. For example, individuals with hypochlorhydria (reduced gastric acid) are much more prone to develop cholera. This may be due to the fact that gastric acid is a key barrier that protects individuals against infection.

Cholera and other waterborne diseases pose an growing threat to people already living at the margins of survival, where populations with a high predominance of blood type $\mathrm{O}$ are especially at risk. People with blood type $\mathrm{O}$ are more expected to develop severe cholera (cholera gravis) than individuals having other blood types. This has been demonstrated in various case-control studies which showed that people with blood type $\mathrm{O}$ were at increased risk of hospitalization due to V. cholerae $\mathrm{O} 1$ biotype El Tor as well as to $V$. cholera 0139 (Glass et al., 1985; Swerdlow et al., 1994; Faruque et al., 1994; Tacket et al., 1995; Harris et al., 2005; Harris et al., 2008). However, no such association has been found for cholera infection with classical $V$. cholera strains (Clemens et al., 1989). A recent study by Heggelund and co-workers (2012) has revealed that the cholera toxin is assumed to be the main culprit of this blood type dependence as they found that that both El Tor and classical cholera toxin B-pentamers bind blood type determinants (with equal affinities). It is therefore confirmed that blood-type dependence is strain specific. The shorter blood type $\mathrm{H}$-determinant characteristic of blood type $\mathrm{O}$ individuals binds with similar binding affinity compared to the A-determinant, however, with different kinetics (Heggelund et al., 2012).

Although many factors are involved in $V$. cholerae virulence, the key agent responsible for the severe diarrhoea is the cholera toxin (CT), which is secreted from vibrios co-expressing a bacteriophage (Davis et al., 2000; Davis and Waldor, 2003). The most recent study in cholera endemic areas in Bangladesh has revealed a direct relationship between susceptibility of cholera infection and specific genes in some people. A number of genetic regions, including genes related to inherent immunity and potassium channels, are found to be associated with cholera (Karlsson et al., 2013). A study by Harris and coworkers (2008) also demonstrated that IgA antibodies, a type of antibody associated with the mucosal immune system, such as the mucosal surface of the intestinal tract, that target several components of the bacteria, are associated with immunity to $V$. cholerae infection.

Natural infection with $V$. cholera $\mathrm{O} 1$ has been reported to induce adaptive immune responses that provide protection against subsequent reinfection with the same pathogen. Studies conducted with volunteers in nonendemic settings have shown that infection with classical biotype $V$. cholera 01 provides $100 \%$ protection from subsequent challenges with a classical biotype strain. However, infection caused by the El Tor biotype of $V$. cholera 01 results in $90 \%$ protection from subsequent 
challenges with an El Tor strain. It was found that individual volunteers were protected for a period of 3 years (Levine et al., 1981). In an endemic area of Bangladesh, Glass and co-workers (1982) reported an initial episode of El Tor cholera, which reduced the risk of a second cholera infection by $90 \%$ over the next several years.

The nutritional status of households has been identified as another risk factor for cholera infection. Evidence has shown that increasing levels of retinol (Vitamin A) deficiency are associated with both a higher risk of infection with $V$. cholerae $\mathrm{O} 1$ and a higher likelihood of developing symptomatic disease if infected (Harris et al., 2008).

Although all age groups seem to be susceptible to cholera infection, still the majority of children are at high risk (Glass and Black, 1992; Sack et al., 2003; Harris et al., 2008). For example, in endemic areas of rural Bangladesh, especially at the Ganges River Delta, children are more likely to be hospitalized with severe illness (Glass et al., 1982). Hartley et al. (2006) reported that direct person-toperson transmission of cholera is still thought to be uncommon. In individual volunteer studies, the infective dose was determined to be $10^{2}$ to $10^{3}$ cells. However, the size of the inoculum needed to cause severe infection is based on the health status of the individual. Genenrally some $10^{5}$ to $10^{8}$ bacterial cells are required to produce disease in healthy people, but a very small inoculum can trigger the disease in individuals with low levels of gastric acid (Sack et al., 2004). Only a small inoculum is required to transmit the disease directly via the faeces of an infected individual, (Pascual et al., 2006).

\subsection{Population and Individual Control Measures}

In both endemic and epidemic cholera settings, the most efficient control measures are the early detection by well-established surveillance systems, announcement of the infection by the governments and health authorities and international organizations such as WHO and CDC, prompt treatment of infected people by administering appropriate medication, providing health education and proper disposal of human waste. In some instances, vaccination is required to protect the other people from cholera infections. Also, in some cases, restrictions on trade and import of mainly fish, seafood, and others foodstuffs from endemic areas in addition to travel restrictions offer some advantages to control the disease But travellers to epidemic areas should be very careful about their eat and drink and scrupulous about personal hygiene. Surveillance by molecular epidemiology and antimicrobial susceptibility in addition to strain-tracking are important tools for cholera control at both national and international levels (WHO, 2014).

Although control measures should be put in place, the cheapest and most effective way of avoiding a cholera outbreak is by providing safe clean drinking water and improved sanitation infrastructure to all. Unfortunately, these basic requirements are still lacking in many parts of developing countries. Statistics mentioned in Table 1 reveal that hundreds of thousands of people have died of cholera in Africa and in Asia between 1995 and 2013. These statistics are based only on reported cases while underreporting and/or underestimating cases remain common in the developing world.

\subsubsection{Vaccines}

\subsubsection{Types of vaccine}

Two types of cholera vaccines are available depending on the route of administration - via injection and oral. For the injectable version, killed whole-cell (WC) cholera vaccines were used during the nineteenth century and still up until 1970. Since then, no injectable vaccines have been used due to their low levels of efficacy, short duration of protection, and their known side-effects and unfavourable safety profile (Mosley et al., 1972). The second type is oral cholera vaccines, which are now widely used because they are easier to administer, more acceptable to recipients, and have a reduced risk of transmitting blood-borne infections (Holmgren and Czerkinsky, 2005; Shin et al., 2011).

The current internationally-licensed cholera vaccine contains, in addition to the killed whole cell vibrios of both classical and EI Tor biotypes, the cholera toxin B subunit. This additive boosts short-term protection against $V$. cholerae infection (Clemens et al., 1989), acting as a potent mucosal immunogen and as an immunoadjuvant (Rask et al., 2000). The two major types of oral vaccines against cholera are the killed whole cell-based and the genetically attenuated live vaccines (Shin et al., 2011). Currently, there are two types of WHO-prequalified oral cholera vaccines, namely Dukoral ${ }^{\circledR}$ and Shanchol ${ }^{\circledR}$, both of which are licensed in many countries (WHO, 2014).

\subsection{Dukoral ${ }^{\circledR}$}

This vaccine is manufactured by Crucell Sweden $A B$, located in Stockholm, Sweden, and consists of killed whole cell $V$. cholerae $\mathrm{O} 1$ with purified recombinant B subunit (WC/rBS) of cholera toxin. Each dose must be diluted in $150 \mathrm{~mL}$ of bicarbonate buffer and in $75 \mathrm{~mL}$ for children. The immunization schedule varies with different age groups. It is administered to adults and children aged $>6$ years in 2 doses; and to children aged $>2$ years and $<6$ years in 3 doses. For both regimens, the recommended minimum time between the two doses is 7 days, whereas the maximum time is 6 weeks. Protection can be predictable after the last dose by one week. It was found that, Dukoral ${ }^{\circledR}$ also generates some cross-protection against enterotoxigenic Escherichia coli (ETEC). Field trials in Bangladesh and Peru have demonstrated that this vaccine is harmless and results in $85 \%$ protection for $4-6$ months throughout various group ages. Although the protection degenerated sharply in young children after 6 months, it persisted at about $60 \%$ after 2 years in older children and adults (WHO, 2014). A re-analysis of the data obtained from the Bangladesh study when using a stochastic model of cholera transmission advocated that the effectiveness of WC/rBS is prominently boosted by herd protection (Faruque et al., 2007a). This vaccine is not approved for use in children aged less than 2 years. 


\subsection{Shanchol ${ }^{\circledR}$}

The Shanchol ${ }^{\circledR}$ vaccine is bivalent and contains killed whole-cell V. cholerae serogroups $\mathrm{O} 1$ and 0139 and is manufactured by Shantha Biotechnics, located in Hyderabad, India; it does not contain a recombinant $B$ subunit, and therefore does not need to be reconstituted in a buffer solution. The immunization schedule is 2 doses given at an interval of 2 weeks for those aged $>1$ year. Shanchol ${ }^{\circledR}$ has provided longer term protection than Dukoral ${ }^{\circledR}$ in children aged $<5$ years, and therefore does not require a booster dose after 6 months in this age group, unlike Dukoral ${ }^{\circledR}$. Shanchol ${ }^{\circledR}$ provided $67 \%$ protection against clinically significant $V$. cholerae 01 cholera in an endemic area for at least 2 years after vaccination. A field trial in Kolkata, India showed a sustained protective efficacy $(65 \%)$ of the vaccine up to 5 years (Bhattacharya et al., 2013). Annexure 2 illustrates a comparison of the currently available oral cholera vaccines.

\subsection{Fecal shedding of live vaccine strains}

A case study about the safety, immunogenicity and shedding level of a live oral $V$. cholerae $01 \mathrm{El}$ Tor vaccine candidate, named Peru-15, was conducted in Bangladesh. It was found that $V$. cholerae, genetically identical with the vaccine strain, was isolated from the stool of only one volunteer (Qadri et al., 2005). lso, the rate of fecal shedding for the same oral Vibrio vaccine Peru-15 was found to be $0.7 \%$ in adults and $7.5 \%$ in children (Bhutta et al., 2009). nother live attenuated cholera vaccine candidate called $V$. cholerae 638 (Cuba) has been studied on volunteers in Havana, Cuba and Maputo, Mozambique during 2005 and 2007. It was found that the fecal shedding rates reached up to $46 \%$ in Mozambique. Moreover the fecal shedding rate was $0 \%$ in the study which was carried out in Kolkata, India during 1999-2004 on the live attenuated V 1.3 vaccine; this means that this vaccine is very safe (Bhutta et al., 2009).

\subsubsection{Future aspects}

Oral cholera vaccines offer short-term protection against cholera infection. However, access to treated and safe water, food hygiene and adequate sanitation are still important and are the main issues to be taken into consideration in control measures. The limitation of global production and supply of the licensed WHO-prequalified cholera vaccines is one of the most important challenges in the future. For example, since its inception in 2013, 1.4 million doses of oral cholera vaccines have been deployed from the stockpile. Thus, a rigorous system of short- and longer-term monitoring and evaluation embedded within the oral cholera vaccines stockpile deployment mechanism is required (WHO, 2014). The design of future vaccine evaluations and efficacy studies are needed to consider the role of herd protection. The hypothetical existence of significant herd protection will have implications for the choice of target populations for cholera vaccination. It is likely that access to the vaccine might be enhanced for groups who do not usually have access to or seek treatment. It remains to be determined how these factors will influence the development of strategies that focus on reaching a particular threshold level of vaccination in order to achieve an acceptable level of protection in a community
(WHO, 2006). Furthermore, there is a call for the development of improved vaccines that confer protection, especially for blood type O individuals (HolNAer et al., (2010). New vaccination strategies are needed to consider information on the blood-group dependence of the disease for this particular group of individuals.

\subsubsection{Hygiene measures}

Recently, countries have made great strides to prevent and respond to cholera outbreaks; nonetheless, many concerns remain about the high proportion of people living under unsanitary conditions. WHO/UNICEF (2012) estimated that 2.5 billion people still live without improved sanitation and these people are at risk of contracting cholera and other diarrheal diseases worldwide. There is a need to extend prevention measures in order to stop cholera and other waterborne diseases by tyintensifying access to improved sources of drinking water and improved sanitation, and by working hang in hand with communities to encourage the change of their behaviour in order to reduce the risks of infection (WHO/UNICEF, 2012). For example in Darfur, Sudan has been offered valuable indications of the cost, impact, and challenges of water and sanitation projects in complex emergencies and of the role of such projects in preventing cholera outbreaks. In May 2004 , only $20 \%$ people of living in areas reachable by the United Nations agencies had access to adequate water, and only about 5\% to proper sanitation; by September 2005, these ratios had risen to $52 \%$ and $76 \%$, respectively. Clearly, despite the enormous effort provided by all humanitarian bodies active in the field for more than a year, a significant number of people still lacked access to minimum water supply and sanitation facilities (WHO, 2006).

\subsection{Environmental Occurrence, Persistence and Survival}

$V$. cholerae has been found not only in freshwater environments, but also in marine water, colonizing the water biota, particularly plankton and attached primarily to crustacean copepods in the zooplankton. Thus the cholera disease appears not to be eradicable due to the fact that $V$. cholerae is a natural inhabitant of the aquatic environment (Valdespino and Garcla-Garcĺa, 2011). De Magny and coworkers (2011) examined the incidence of cholera and occurrence of pathogenic $V$. cholerae including both serogroups $\mathrm{O} 1$ and $\mathrm{O} 139$ within zooplankton. They found that two dominant zooplankton groups were consistently associated with the detection of $V$. cholerae and/or occurrence of cholera cases, namely rotifers and cladocerans, in addition to copepods. Local differences indicate that there are subtle ecological factors that can influence interactions between $V$. cholerae, its plankton hosts, and the incidence of cholera.

\subsection{Detection Methods}

\subsubsection{Culture-based methods}

Detection, enumeration and identification of $V$. cholerae 
from the environmental and medical samples by culturebased methods followed by biochemical and serological tests have been established in many standard methods (ISO, 2007; APHA, 2012; CDC, 2015). The procedures for detection of $V$. cholerae by culture-based methods includes growth in enrichment by using salt-free non-selective enrichment media such as alkaline peptone water (APW), buffered peptone water (BPW), brain heart infusion (BHI), marine broth or Luria broth (LB) at $37^{\circ} \mathrm{C}$ for $18-24 \mathrm{~h}$. This step is very important for recovering the stressed or injured $V$. cholerae cells, therefore avoiding the false-negative results (Reissbrodt et al., 2003). Thereafter, selective isolation of Vibrio species is achieved by plating on a selective agar culture plate, namely thiosulphate citrate bile salts sucrose (TCBS) agar, for 24 to $48 \mathrm{~h}$ at $37^{\circ} \mathrm{C}$, which allows colonies of V. cholerae to ferment sucrose and produce yellow colonies. The TCBS agar is still a golden standard culture medium. It is widely used and extremely useful for isolating $V$. cholerae from different water and food samples and as well as from human clinical specimens (Colwell, 1984; Farmer et al., 2003; 2005). These yellow colonies are subjected to further biochemical and serological tests for the identification of $V$. cholerae (Cash et al., 1974; Nair et al., 1987).

During a cholera outbreak, there is no need to do a large number of biochemical tests to confirm a culture as $V$. cholerae. Agglutination in $V$. cholerae $\mathrm{O} 1$ or 0139 serum is a diagnostic method that can be followed by biochemical testing for the first few isolates to confirm the presence of this patohgen (APHA, 2012). Haemolysis of sheep blood cells has been traditionally used as one of several tests to distinguish the two biotypes of $V$. cholerae 01 . The classic biotype is non-haemolytic, while the El Tor biotype is haemolytic; non-01 V. cholerae strains are usually haemolytic (Karaolis et al., 2001). Commercial immunoassays for testing the enterotoxin of $V$. cholerae are currently available and they allow growing the culture in special media (APHA, 2012). Recently the chromogenic and fluorogenic media such as chromID ${ }^{\mathrm{TM}}$ Vibrio Agar, HiCrome Vibrio agar, Vibrio chromogenic agar, and chromogenic Vibrio cholerae agar for the detection of Vibrio cholerae and other Vibrio species have been used (Duan and Su, 2005; Richards et al., 2005; Eddabra et al., 2011).

Madoroba and Momba (2010) collected 594 water samples aseptically once a month over a 4-month period from 32 sampling sites on major rivers in the Mpumalanga Province of South Africa. They used three different approaches for collecting samples from the abovementioned rivers. Two of the sampling methods involved placing either sterile Moore gauzes or tampons (tied at the centre to strong twine) in duplicate in flowing water at various river sites. Weights were also tied to the gauzes and tampons to ensure their submergence in the river water. The gauzes and tampons were left in the various rivers for 5 - 6 days in order to maximize trapping of $V$. cholerae. The third method of sampling involved the collection of $5 \mathrm{~L}$ of water in sterile containers, followed by sealing of the containers and appropriate labelling. They found that almost similar numbers of $V$. cholerae were obtained from water samples that were collected in sterile containers directly ( 7 isolates) and from gauzes that were submerged in the river water for 5 to 6 days (8 isolates). No $V$. cholerae were isolated from water samples collected using tampons. They concluded that both methods are suitable for isolating these bacteria from environmental samples. Tampons were found to be unsuitable for obtaining $V$. cholerae from water sources as no isolates were recovered with this method. This may be due to some inhibiting substances present in tampons.

\subsubsection{Molecular-based methods}

Several molecular-based methods have been used for $V$. cholerae $\mathrm{O} 1$ and $\mathrm{O} 139$ detection in environmental samples. These methods have high sensitivity, specificity, and speed. The methods used for $V$. cholerae detection by conventional PCR and/or real-time PCR are well established (Wang et al., 2007; Tebbs et al., 2011; Teklehaimanot et al., 2014). Many research studies have identified Vibrio cholerae strains using 16S rRNA sequencing, pulsed-field gel electrophoresis (PFGE), nested and multiplex PCR (Chakraborty et al., 1999; Kong et al., 2002; Tarr et al., 2007; Mendes et al., 2008; Keshav et al., 2010). Moreover, molecular detection and characterization of virulence factors and cholera toxin genes (ctxs) of Vibrio cholerae have been investigated in many studies (Lipp et al., 2003; Blackstone et al., 2007; Son et al., 2011).

Other rapid methods have been developed for environmental monitoring of $V$. cholerae, including the use of monoclonal fluorescent antibodies and immunochromatographic dipsticks for LPS detection (Nato et al., 2003; Goel et al., 2005). Chen et al. (2014) developed a new monoclonal antibody (McAb) pair, named IXiao3G6 and IXiao1D9, which is specifically against $V$. cholerae 01 serotype Ogawa. In addition, they developed immunochromatographic lateral flow device (LFD) using this $\mathrm{McAb}$ pair for the highly specific and rapid (within 5 min) detection of Ogawa.

Wang et al. (2010) developed an immunofluorescentaggregation (IFAG) assay to detect $V$. cholerae $\mathrm{O} 1$ and 0139 in estuarine water samples. They compared the results of IFAG with the conventional culture method and real-time PCR. Their results showed that the percentage positive by the IFAG assay method was $19.9 \%$, which was significantly higher compared to the conventional culture method $(10.3 \%)$, but lower than that of real-time PCR (29.5\%). They concluded that the IFAG method, with a high specificity and a relatively high sensitivity, may be used for the detection and isolation of $V$. cholerae in environmental water samples.

Recently, Yu et al. (2015) developed a nucleic acidsensing platform for detection of toxigenic Vibrio cholerae serogroups $\mathrm{O} 1$ and 0139 . The sensitivity and specificity $(100 \%)$ of the platform showed excellent diagnostic capabilities when tested with 168 spiked stool samples. Their study highlighted the potential of combining a dryreagent-based nucleic acid amplification assay with an electrochemical genosensor in a more convenient, sensitive, and sequence-specific detection strategy for multiple target nucleic acids. 


\subsubsection{Immune-diagnosis/detection of the pathogen infection}

Challenges still remain vis-à-vis the diagnosis and dection of Vibrio cholerae infections, due to limited resources especially in developing countries. The most commonly performed methods for serodiagnosis of Vibrio cholerae $\mathrm{O} 1$ infection comprise the measurement of antibacterial antibodies by agglutination or vibriocidal antibody essays (Barret et al., 1994). The vibriocidal antibody test has been used widely for serologic surveys as it is a friendly method based on the titration of large numbers of sera by microtiter procedure. According to Barret et al., (1994), the acquisition of antibody through natural exposure or vaccination has demonstrated obvious correlation to immunity on a population basis and in volunteers challenged with the organism.

More procedures such as the indirect hemagglutination test and enzyme-linked immunosorbent assays (ELISAs) and cell culture models for detecting cholera toxin (CT) have been also reported to provide marked improvement in the ability to measure antitoxic antibodies (Barret et al., 1994). Rapid diagnostic tests such as reverse passive latex agglutination test (RP LA) have also been proved effective for the detection of CT (Yamasaki et al., 2013). Recently, various tests have been developed and they mostly focus on the detection of the lipopolysaccharide of $V$. cholerae 01 and $\mathrm{O} 139$ by monoclonal antibodies, using the vertical-flow immunochromatography principle (Keddy et al, 2013). These are commercial membrane-based rapid diagnostic tests that have been used to detect the presence of cholera infection under laboratory and field conditions with variable sensitivity and specificity. The immunochromatographic Test Strip developed by Yamasaki et al., (2013) demonstrated the capability to detect the CT in culture supernatant of all 15 toxigenic $V$. cholerae isolates examined, whereas no false-positive signal was detected in all 5 nontoxigenic $V$. cholerae isolates examined. A combination of different target analytes for example, immunoassay which detects the existence of CT can result in the surveillance of toxigenic $V$. cholerae.

\subsection{Data on occurrence}

2.2.1 Excreta in the environment (fecal waste, night soil and dry latrines)

The occurrence of toxigenic $V$. cholerae in water is typically associated with fecal pollution. Several research studies have detected $V$. cholerae in human, domestic and farm animal faeces (Kay et al., 1994; Visser et al., 1999; Cox et al., 2005; Cabral, 2010). The person infected with cholera is able to excrete $10^{6} \mathrm{~V}$. cholerae cells per gram faeces (Viraraghavan et al., 2007). Keshav et al. (2010) investigated the occurrence of $V$. cholerae in animal faecal samples collected in rural areas in the Vhembe region of the Limpopo Province in South Africa. In their work, $V$. cholerae 01 was detected in 17 out of 74 cow and (3/74) chicken faeces samples, of which (9/17) cow faeces samples and $(3 / 3)$ chicken faeces samples tested positive for toxigenic $V$. cholerae 01.

Although much research has been carried out concerning the occurrences of $V$. cholerae in different aquatic environments, fish, shellfish and food stuffs, recent data and statistics are still not available about the occurrence of $V$. cholerae in night-soil and dry latrines. In a case study by Bart et al. (1970) V. cholerae from night-soil and latrines was investigated during epidemics of classical and El Tor cholera in East Pakistan. Findings of this study revealed only 2 classical Inaba isolates that were isolated from 9906 individual latrine and pooled communal nightsoil samples, whereas in the Chittagong area, from 62588 similar samples, 2 classical Inaba and 52 El Tor Ogawa isolates were detected. In areas where cases due to both biotypes were occurring simultaneously, El Tor Ogawa vibrios were isolated 10 times more frequently than the classical Inaba.

The occurrence of $V$. cholerae was found to be higher in human faeces $\left(2.2 \times 10^{8} \mathrm{CFU} / \mathrm{g}\right)$, cow dung $\left(1.1 \times 10^{7}\right.$ $\mathrm{CFU} / \mathrm{g})$ and poultry manure samples $\left(5.9 \times 10^{7} \mathrm{CFU} / \mathrm{g}\right)$, whereas a lower load of $V$. cholerae was observed in compost samples $\left(2.2 \times 10^{3} \mathrm{CFU} / \mathrm{g}\right)$ (Uddin et al., 2012). Table 5 summarises the occurrence of $V$. cholera in various environmental samples (Table 5).

Table 5. Occurrence of $V$. cholerae in environmental sources including fecal waste, night soil, dry latrines

\begin{tabular}{|c|c|c|c|c|c|c|c|}
\hline Area & $\begin{array}{l}\text { Period } \\
\text { of Study }\end{array}$ & Matrix & $\begin{array}{c}\text { Detection } \\
\text { Method }\end{array}$ & $\begin{array}{l}\text { Sample } \\
\text { Volume }\end{array}$ & $\begin{array}{c}\text { Percent } \\
\text { Positive } \\
\text { (\# of } \\
\text { Samples) } \\
\end{array}$ & $\begin{array}{c}\text { Concentration } \\
\text { Average CFU }^{\mathrm{a}} / \mathrm{L} \text {, } \\
\mathrm{MPN}^{\mathrm{b}} / \mathrm{L} \text {, or } \\
\mathrm{CFU} / \mathrm{g} \\
\end{array}$ & Reference \\
\hline Bangladesh & $\mathrm{NR}^{\mathrm{c}}$ & Patient Faeces & Culture & $1.0 \mathrm{mg}$ & NR & $2.2 \mathrm{E}+05$ & Uddin et al., 2012 \\
\hline Bangladesh & NR & Compost & Culture & $1.0 \mathrm{mg}$ & NR & 2.2 & Uddin et al., 2012 \\
\hline Bangladesh & NR & Cow Faeces & Culture & $1.0 \mathrm{mg}$ & NR & $1.1 \mathrm{E}+04$ & Uddin et al., 2012 \\
\hline Bangladesh & NR & Poultry Faeces & Culture & $1.0 \mathrm{mg}$ & NR & $5.9 \mathrm{E}+04$ & Uddin et al., 2012 \\
\hline East Pakistan $^{\mathrm{d}}$ & $\begin{array}{c}1968 \text { to } \\
1969\end{array}$ & Night soil & Culture & NR & $0.12 \%$ & NR & Bart et al., 1970 \\
\hline East Pakistan $^{\mathrm{e}}$ & $\begin{array}{c}1968 \text { to } \\
1969\end{array}$ & Night soil & Culture & NR & $0.006 \%$ & NR & Bart et al., 1970 \\
\hline
\end{tabular}




\begin{tabular}{|c|c|c|c|c|c|c|c|}
\hline Area & $\begin{array}{l}\text { Period } \\
\text { of Study }\end{array}$ & Matrix & $\begin{array}{c}\text { Detection } \\
\text { Method }\end{array}$ & $\begin{array}{l}\text { Sample } \\
\text { Volume }\end{array}$ & $\begin{array}{c}\text { Percent } \\
\text { Positive } \\
\text { (\# of } \\
\text { Samples) }\end{array}$ & $\begin{array}{c}\text { Concentration } \\
\text { Average CFU } / \mathrm{L} \text {, }^{\mathrm{a}} \mathrm{MPN}^{\mathrm{b}} / \mathbf{L} \text {, or } \\
\mathrm{CFU} / \mathrm{g}\end{array}$ & Reference \\
\hline East Pakistan & $\begin{array}{l}1965 \\
\text { to } 1966\end{array}$ & $\begin{array}{l}\text { Asymptomatic } \\
\text { cholera patients } \\
\text { stool }\end{array}$ & Culture & $1.0 \mathrm{~g}$ & NR & $1.0 \mathrm{E}+03 \mathrm{CFU}$ & $\begin{array}{l}\text { Nelson et al., } \\
\text { 2009; Mosley et } \\
\text { al., } 1968\end{array}$ \\
\hline Philippines & $\begin{array}{l}1964 \\
\text { to } 1966\end{array}$ & $\begin{array}{l}\text { Patient faeces } \\
\text { (watery) }\end{array}$ & $\begin{array}{l}\text { Serological } \\
\text { examinations }\end{array}$ & $1.0 \mathrm{ml}$ & $21.7 \%$ & $\begin{array}{c}1.0 \mathrm{E}+04 \text { to } 1.0 \\
\mathrm{E}+06\end{array}$ & Dizon et al., 1967 \\
\hline South Africa & 2008 & Cow Faeces & PCR & $0.15 \mathrm{~g}$ & $\begin{array}{l}74.3 \% \\
(55 / 74)\end{array}$ & NR & $\begin{array}{c}\text { Keshav et al., } \\
2010\end{array}$ \\
\hline South Africa ${ }^{\mathrm{f}}$ & 2008 & Cow Faeces & PCR & $0.15 \mathrm{~g}$ & $\begin{array}{l}22.9 \% \\
(17 / 74)\end{array}$ & NR & $\begin{array}{l}\text { Keshav et al., } \\
2010\end{array}$ \\
\hline South Africa $^{g}$ & 2008 & Cow Faeces & PCR & $0.15 \mathrm{~g}$ & $\begin{array}{l}12 \% \\
(9 / 74)\end{array}$ & NR & $\begin{array}{c}\text { Keshav et al., } \\
2010\end{array}$ \\
\hline South Africa & 2008 & Chicken Faeces & PCR & $0.15 \mathrm{~g}$ & $\begin{array}{l}10.8 \% \\
(8 / 74)\end{array}$ & NR & $\begin{array}{c}\text { Keshav et al., } \\
2010\end{array}$ \\
\hline South Africa $^{\mathrm{h}}$ & 2008 & Chicken Faeces & PCR & $0.15 \mathrm{~g}$ & $\begin{array}{c}4 \% \\
(3 / 74)\end{array}$ & NR & $\begin{array}{c}\text { Keshav et al., } \\
2010\end{array}$ \\
\hline South Africa & 2008 & Goats Faeces & PCR & $0.15 \mathrm{~g}$ & $\begin{array}{l}2.7 \% \\
(2 / 74)\end{array}$ & NR & $\begin{array}{c}\text { Keshav et al., } \\
2010\end{array}$ \\
\hline South Africa & 2008 & Donkeys Faeces & PCR & $0.15 \mathrm{~g}$ & $\begin{array}{l}5.4 \% \\
(4 / 74)\end{array}$ & NR & $\begin{array}{l}\text { Keshav et al., } \\
2010\end{array}$ \\
\hline South Africa & 2008 & Pig Faeces & PCR & $0.15 \mathrm{mg}$ & $\begin{array}{c}4 \% \\
(3 / 74)\end{array}$ & NR & $\begin{array}{c}\text { Keshav et al., } \\
2010\end{array}$ \\
\hline South Africa & 2008 & Pigeons Faeces & PCR & $0.15 \mathrm{mg}$ & $\begin{array}{l}1.3 \% \\
(2 / 74)\end{array}$ & NR & $\begin{array}{c}\text { Keshav et al., } \\
2010\end{array}$ \\
\hline NR & NR & Faeces & Culture & $1.0 \mathrm{mg}$ & NR & $\begin{array}{c}1.0 \mathrm{E}+03 \text { to } 1.0 \\
\mathrm{E}+06\end{array}$ & WHO, 2011a \\
\hline NR & NR & Human Faeces & Culture & $1.0 \mathrm{~g}$ & NR & $1.0 \mathrm{E}+06$ & $\begin{array}{l}\text { Viraraghavan et } \\
\text { al., } 2007\end{array}$ \\
\hline
\end{tabular}

${ }^{a}$ CFU: Colony Forming Unit; ${ }^{b} \mathrm{MPN}$ : Most Probable Number; ${ }^{\mathrm{c}}$ NR: Not Reported; Microorganism ${ }^{\mathrm{d}}$ El Tor Ogawa; ${ }^{\mathrm{e}}$ Classical Inaba; ${ }^{\mathrm{f}} \mathrm{O} 1 ;{ }^{\mathrm{g}, \mathrm{h}}$ Toxigenic $\mathrm{O} 1$

\subsubsection{Sewage}

In many developing countries, sewage is discharged directly into the rivers, it leaks into groundwater and is used for irrigation purposes without any prior treatment or with inadequate treatment. It was found that $80 \%$ of the globally produced wastewater does not receive any kind of treatment, whereas only $20 \%$ receives suitable treatment (UNESCO, 2012). The pollution of rivers and groundwater by sewage causes the spread of diseases and environmental deterioration. Control of sewage discharges and proper water treatment practices have dramatically reduced widespread epidemics in the United States. However, one outbreak of cholera occurred in 1981, caused by wastewater contamination of an oil rig's potable water system, resulting in 17 cases of severe diarrhoea (CDC, 1982). It is only necessary to remove cholera from sewage if failure to do so will result in the transmission of the disease. Typically, this occurs if the treated wastewater contaminates food that is eaten raw. For example, cabbage used for preparing coleslaw was implicated in case-control studies in the Peruvian outbreak (Swerdlow et al., 1992); the cabbage may have been irrigated with water contaminated with sewage. Tamplin and Parodi (1991) worked in Peru at the height of the epidemic period, and they reported $10^{5}$ and $10^{2} \mathrm{~V}$. cholerae cells $/ 100 \mathrm{~mL}$ in municipal sewage in Lima and Puno, respectively.

Explosive epidemics of cholera have been documented in Peru and Chile and have been associated with the consumption of sewage-contaminated vegetables (Shuval, 1991). V. cholerae El Tor was found in sewage (oxidation pond), and levels of 10 to $10^{4}$ organisms $/ 100 \mathrm{~mL}$ during a cholera epidemic have been reported (Kott and Betzer, 1972). In a case study to determine the efficiency of 14 sewage treatment plants in the Mpumalanga Province in South Africa, among all the other pathogenic bacteria detected, it was found that Vibrio spp. were the most encountered in the raw and the treated sewage effluent. This is an indication of the predisposition of the community to cholera (Samie et al., 2009). Also in the same country, toxigenic $V$. cholerae were detected in the final effluents of wastewater treatment plants as follows: Baviaanspoort (35.3\%), Refilwe (21.9\%) and Rayton (9.4\%) (Dungeni et al., 2010). Moreover, in a study conducted by Teklehaimanot et al. $(2014$; 2015) on the effluents of activated sludge treatment plants, the PCR results revealed that between 20 and $60 \%$ of samples tested positive for Vibrio cholerae. Table 6 illustrates the occurrence of $V$. cholerae in sewage in some countries of the world. 
Table 6. Occurrence of $V$. cholerae in sewage

\begin{tabular}{|c|c|c|c|c|c|c|c|c|}
\hline Area & $\begin{array}{c}\text { Period } \\
\text { of } \\
\text { Study }\end{array}$ & Microorganism & Matrix & $\begin{array}{l}\text { Detection } \\
\text { Method }\end{array}$ & $\begin{array}{l}\text { Sample } \\
\text { volume }\end{array}$ & $\begin{array}{c}\text { Percent } \\
\text { Positive } \\
\text { (\# of } \\
\text { Samples) }\end{array}$ & $\begin{array}{c}\text { Concentration } \\
\text { Average } \\
\mathrm{CFU}^{\mathrm{a}} / \mathbf{L}, \\
\mathrm{MPN}^{\mathrm{b}} / \mathbf{L} \text {, or } \\
\mathrm{CFU} / \mathrm{g}\end{array}$ & Reference \\
\hline $\begin{array}{l}\text { Brazil, } \\
\text { Peru, } \\
\text { Mexico, } \\
\text { India }\end{array}$ & $\begin{array}{c}1977 \text { to } \\
1991\end{array}$ & V. cholerae $\mathrm{O} 1$ & Waste water & PCR & $\mathrm{NR}^{\mathrm{c}}$ & $96.7 \%$ & $\mathrm{NR}^{\mathrm{c}}$ & $\begin{array}{c}\text { Rivera et al., } \\
1995\end{array}$ \\
\hline $\begin{array}{l}\text { Brazil, } \\
\text { Peru, } \\
\text { Mexico, } \\
\text { India }\end{array}$ & $\begin{array}{c}1977 \text { to } \\
1991\end{array}$ & V. cholerae 0139 & Waste water & PCR & NR & $100 \%$ & NR & $\begin{array}{c}\text { Rivera et al., } \\
1995\end{array}$ \\
\hline Egypt & $\begin{array}{c}2005 \text { to } \\
2007\end{array}$ & Vibrio spp. & $\begin{array}{c}\text { Raw } \\
\text { wastewater }\end{array}$ & Culture & $100 \mathrm{~mL}$ & $100 \%$ & 100 to $1.0 \mathrm{E}+04$ & $\begin{array}{c}\text { El-Lathy et al., } \\
2009\end{array}$ \\
\hline Egypt & NR & V. cholerae & $\begin{array}{c}\text { Treated } \\
\text { wastewater }\end{array}$ & Culture & $100 \mathrm{~mL}$ & NR & 10 to 100 & $\begin{array}{c}\text { Hassanin et al., } \\
2013\end{array}$ \\
\hline India & NR & $\begin{array}{c}\text { Toxigenic } V . \\
\text { cholerae }\end{array}$ & Sewage & PCR & $\mathrm{mL}$ & $10 \%$ & NR & $\begin{array}{l}\text { Yadava et al., } \\
2013\end{array}$ \\
\hline India & NR & $\begin{array}{l}V . \text { cholerae non- } \\
\text { O1 }\end{array}$ & Sewage & PCR & $\mathrm{mL}$ & $70 \%$ & NR & $\begin{array}{l}\text { Yadava et al., } \\
2013\end{array}$ \\
\hline Peru & NR & V. cholerae & Sewage water & Culture & $100 \mathrm{~mL}$ & NR & 10 to $1.0 \mathrm{E}+04$ & $\begin{array}{l}\text { Tamplin and } \\
\text { Parodi ,1991 }\end{array}$ \\
\hline $\begin{array}{l}\text { South } \\
\text { Africa }\end{array}$ & $\begin{array}{c}2007 \text { to } \\
2008\end{array}$ & $\begin{array}{c}\text { Toxigenic } V . \\
\text { cholerae }\end{array}$ & $\begin{array}{l}\text { Effluent of } \\
\text { Refiwe } \\
\text { Wastewater } \\
\text { plants }\end{array}$ & PCR & NR & $21.9 \%$ & NR & $\begin{array}{c}\text { Dungeni et al., } \\
2010\end{array}$ \\
\hline $\begin{array}{l}\text { South } \\
\text { Africa }\end{array}$ & $\begin{array}{l}2007 \text { to } \\
2008\end{array}$ & $\begin{array}{c}\text { Toxigenic } V . \\
\text { cholerae }\end{array}$ & $\begin{array}{l}\text { Effluent of } \\
\text { Rayton } \\
\text { Wastewater } \\
\text { plants }\end{array}$ & PCR & NR & $9.4 \%$ & NR & $\begin{array}{c}\text { Dungeni et al., } \\
2010\end{array}$ \\
\hline $\begin{array}{l}\text { South } \\
\text { Africa }\end{array}$ & $\begin{array}{c}2007 \text { to } \\
2008\end{array}$ & $\begin{array}{c}\text { Toxigenic } V . \\
\text { cholerae }\end{array}$ & $\begin{array}{c}\text { Effluent of } \\
\text { Baviaanspoort } \\
\text { Wastewater } \\
\text { plants }\end{array}$ & PCR & NR & $35.3 \%$ & NR & $\begin{array}{c}\text { Dungeni et al., } \\
2010\end{array}$ \\
\hline $\begin{array}{l}\text { South } \\
\text { Africa }\end{array}$ & $\begin{array}{l}2012 \text { to } \\
2013\end{array}$ & Vibrio spp. & $\begin{array}{c}\text { Treated } \\
\text { wastewater }\end{array}$ & Culture & $100 \mathrm{~mL}$ & NR & 0.1 to $1.0 \mathrm{E}+03$ & $\begin{array}{l}\text { Nongogo and } \\
\text { Okoh, } 2014\end{array}$ \\
\hline $\begin{array}{l}\text { South } \\
\text { Africa }\end{array}$ & $\begin{array}{l}2011 \text { to } \\
2012\end{array}$ & $\begin{array}{l}\text { Toxigenic } \\
\text { V. cholerae }\end{array}$ & $\begin{array}{c}\text { Treated } \\
\text { wastewater }\end{array}$ & PCR & NR & 20 to $60 \%$ & NR & $\begin{array}{c}\text { Teklehaimanot } \\
\text { et al., 2014; } \\
2015\end{array}$ \\
\hline $\begin{array}{l}\text { South } \\
\text { Africa }\end{array}$ & $\begin{array}{l}2011 \text { to } \\
2012\end{array}$ & V. cholerae & $\begin{array}{c}\text { Effluent } \\
\text { wastewater }\end{array}$ & Culture & NR & $93 \%$ & NR & $\begin{array}{c}\text { Teklehaimanot } \\
\text { et al., } 2015\end{array}$ \\
\hline $\begin{array}{l}\text { South } \\
\text { Africa }\end{array}$ & $\begin{array}{l}2011 \text { to } \\
2012\end{array}$ & V. cholerae & $\begin{array}{c}\text { Effluent } \\
\text { wastewater }\end{array}$ & PCR & NR & 20 to $60 \%$ & NR & $\begin{array}{c}\text { Teklehaimanot } \\
\text { et al., } 2015\end{array}$ \\
\hline NR & NR & V. cholerae & Raw sewage & Culture & $100 \mathrm{~mL}$ & NR & $1.0 \mathrm{E}+06$ & AWWA, 2006 \\
\hline NR & NR & $V$. cholerae & $\begin{array}{c}\text { Untreated } \\
\text { wastewater }\end{array}$ & Culture & $\mathrm{L}$ & NR & 100 to $1.0 \mathrm{E}+06$ & WHO, 2011a \\
\hline
\end{tabular}

${ }^{\mathrm{a}} \mathrm{CFU}$ : Colony Forming Unit; ${ }^{\mathrm{b}} \mathrm{MPN}$ : Most Probable Number; ${ }^{\mathrm{c}} \mathrm{NR}$ : Not Reported

\subsubsection{Manure}

The contamination of vegetables, fruits and other edible foodstuffs with $V$. cholerae is mainly due to the use of sewage or manure directly as a fertilizer. Therefore proper animal manure treatment and extensive management is highly recommended before it is used as a fertilizer
(Abakpa et al., 2013). The same authors examined 336 environmental samples comprising soil, water, manure and vegetables for the presence of $V$. cholerae. The samples were collected from some selected households in Zaria, Nigeria. Results revealed 20\% Vibrio cholerae 01 from totally confirmed Vibrio isolates (5) from manure samples. Mossel et al. (1992) suggested a strategy applicable to the 
acceptance of imported foods for avoiding the use of manure and/or sewage for fertilization and faecally contaminated water for irrigation or processing and maintaining worker hygiene and sanitation practices during harvesting, processing and packaging. Table 7 illustrates the occurrence of $V$. cholera and/or biotypes.

Table 7. Occurrence in manure

\begin{tabular}{|c|c|c|c|c|c|c|c|c|}
\hline Area & $\begin{array}{c}\text { Period } \\
\text { of } \\
\text { Study }\end{array}$ & Matrix & Microorganism & $\begin{array}{c}\text { Detection } \\
\text { Method }\end{array}$ & $\begin{array}{l}\text { Sample } \\
\text { Volume }\end{array}$ & $\begin{array}{c}\text { Percent } \\
\text { Positive } \\
\text { (\# of } \\
\text { Samples) }\end{array}$ & $\begin{array}{c}\text { Concentration } \\
\text { Average CFU }^{\mathrm{a}} / \mathrm{L} \text {, } \\
\mathrm{MPN}^{\mathrm{b}} / \mathbf{L} \text {, or } \\
\text { CFU/g }\end{array}$ & Reference \\
\hline Bangladesh & $\mathrm{NR}^{\mathrm{c}}$ & Compost & V. cholerae & Culture & $1 \mathrm{~g}$ & $\begin{array}{c}62.5 \% \\
(15 / 24)\end{array}$ & $2.2 \mathrm{E}+03$ & $\begin{array}{c}\text { Uddin et al., } \\
2012\end{array}$ \\
\hline Nigeria $^{\mathrm{d}}$ & 2006 & Manure & O1 biotype & Culture & $100 \mathrm{~g}$ & $20 \%$ & NR & $\begin{array}{l}\text { Abakpa et } \\
\text { al., } 2013\end{array}$ \\
\hline
\end{tabular}

${ }^{\mathrm{a}} \mathrm{CFU}$ : Colony Forming Unit; ${ }^{\mathrm{b}} \mathrm{MPN}$ : Most Probable Number; ${ }^{\mathrm{c} N R}$ : Not Reported; ${ }^{\mathrm{d}}$ Matrix is 01 biotype, 1 isolate out of 5. The test was based on presence/absence.

\subsubsection{Surface water}

Surface water is a natural habitat for $V$. cholerae where it reproduces and survives in relationship with other organisms. Vibrio. cholerae has been detected during both endemic and non-endemic periods of cholera in several types of surface water including rivers, lakes and estuaries (Shukla et al., 1995; Jackson and Beney, 2000; El-Lathy, 2009; Wang et al., 2007, 2010; Karlsson et al., 2013).

In 2010 and during the cholera outbreak in Haiti, Hill et al. (2011) collected surface water samples from eight freshwater bodies from different sites on the Artibonite River, and irrigation canals and six marine water samples. They found $V$. cholerae 01, serotype Ogawa, ctxA-positive strains in two irrigation canals. Both of these canals were used for drinking water by the local population, and communities near the canals were heavily affected by the outbreak. Furthermore, by the tcpA sequencing analyses of the freshwater and human isolates they found that isolates from both types of samples matched that of CIRS 101, an altered El Tor strain from Bangladesh, and the $\operatorname{ct} x A B$ sequences matched those of the sequences from strains isolated in 2007 during an outbreak in Orissa, India (Talkington et al., 2011). In South Africa, Momba et al. (2006) collected surface water samples from the Lenge Dam, the Tyume River, the Sityi River and the NAikina River. Their results showed the presence of $V$. cholerae in all surface water samples by culture methods and $25 \%$ of the isolated organisms were found to be potentially toxigenic $V$. cholerae. Also in another study, Madoroba and Momba (2010) reported V. cholerae in the Gutshwa, Komati and Crocodile Rivers in Mpumalanga Province. In South Africa in August 2000, the first cases of a cholera outbreak were reported from the outskirts of Empangeni in northern KwaZulu-Natal that then spread to seven of South Africa's nine provinces. There were more than 114000 cases and 260 reported deaths reported by the end of January 2002, nearly all from KwaZulu-Natal. The outbreak developed into the most serious epidemic yet experienced in South Africa.

In Argentina, Aulet et al., (2007) investigated 18 water samplings collected from the Salí River (in Canal Norte and Banda) and the Lules River. They found that all isolated $V$. cholerae corresponded to $V$. cholerae non-O1 and non-O139 (Lules 26\%, Canal Norte 33\% and Banda 41\%). Du Preez et al. (2010) collected 99 estuarine water samples at six sites in Beira, Mozambique. An additional 54 samples were collected from rural areas around Beira, which included three freshwater lake samples, 15 river samples, five pond samples, and four estuarine water samples. The samples were analysed for the presence of $V$. cholerae $\mathrm{O} 1$ and 0139. Their results showed the presence of $V$. cholerae 01 only, in nine (32.1\%) of the total of 28 water samples which comprised river, estuary, lake and pond water. Table 8 illustrates the occurrence of $V$. cholerae in surface water sources in various countries.

Table 8. Occurrence in surface water

\begin{tabular}{|c|c|c|c|c|c|c|c|c|}
\hline Area & $\begin{array}{l}\text { Period } \\
\text { of } \\
\text { Study }\end{array}$ & Matrix & Detection Method & Microorganism & $\begin{array}{l}\text { Sample } \\
\text { volume }\end{array}$ & $\begin{array}{c}\text { Percent } \\
\text { Positive } \\
\text { (\# of } \\
\text { Samples) }\end{array}$ & $\begin{array}{c}\text { Concentration } \\
\text { Average } \\
\mathrm{CFU}^{\mathrm{a}} / \mathrm{L}, \\
\mathrm{MPN}^{\mathrm{b}} / \mathrm{L} \text {, or } \\
\mathrm{CFU} / \mathrm{g}\end{array}$ & Reference \\
\hline Argentina & $\begin{array}{l}2003 \\
\text { to } \\
2005\end{array}$ & Lules river & Direct Immuno-fluorescence & Non-01 \& 0139 & $\mathrm{NR}^{\mathrm{c}}$ & $26 \%$ & NR & $\begin{array}{l}\text { Aulet et al., } \\
2007\end{array}$ \\
\hline Argentina & $\begin{array}{l}2003 \\
\text { to } \\
2005\end{array}$ & $\begin{array}{l}\text { Canal } \\
\text { Norte }\end{array}$ & Direct Immuno-fluorescence & Non-01 \& 0139 & NR & $33 \%$ & NR & $\begin{array}{l}\text { Aulet et al., } \\
2007\end{array}$ \\
\hline
\end{tabular}




\begin{tabular}{|c|c|c|c|c|c|c|c|c|}
\hline Area & $\begin{array}{l}\text { Period } \\
\text { of } \\
\text { Study }\end{array}$ & Matrix & Detection Method & Microorganism & $\begin{array}{l}\text { Sample } \\
\text { volume }\end{array}$ & $\begin{array}{l}\text { Percent } \\
\text { Positive } \\
\text { (\# of } \\
\text { Samples) }\end{array}$ & $\begin{array}{c}\text { Concentration } \\
\text { Average } \\
\mathrm{CFU}^{\mathrm{a}} / \mathrm{L} \text {, } \\
\mathrm{MPN}^{\mathrm{b}} / \mathrm{L} \text {, or } \\
\mathrm{CFU} / \mathrm{g} \\
\end{array}$ & Reference \\
\hline Argentina & $\begin{array}{l}2003 \\
\text { to } \\
2005\end{array}$ & $\begin{array}{l}\text { Banda } \\
\text { river }\end{array}$ & Direct Immuno-fluorescence & $\begin{array}{l}\text { Non-01 and } \\
\text { O139 }\end{array}$ & NR & $41 \%$ & NR & $\begin{array}{l}\text { Aulet et al., } \\
\quad 2007\end{array}$ \\
\hline Azerbaijan & NR & $\begin{array}{l}\text { Fresh } \\
\text { water }\end{array}$ & Culture/ PCR & $\begin{array}{l}\text { Non toxigenic } V . \\
\text { cholerae } \mathrm{O} 1\end{array}$ & NR & $57 \%$ & NR & $\begin{array}{c}\text { Rashid et al., } \\
2013\end{array}$ \\
\hline Bangladesh & 1986 & $\begin{array}{l}\text { River and } \\
\text { pond }\end{array}$ & $\begin{array}{l}\text { Fluorescence } \\
\text { staining } \\
\text { method }\end{array}$ & V. cholerae & $\mathrm{mL}$ & NR & 1 & $\begin{array}{l}\text { Brayton et } \\
\text { al., } 1987\end{array}$ \\
\hline Bangladesh & $\begin{array}{l}1997 \\
\text { to } \\
2000\end{array}$ & $\begin{array}{l}\text { Surface } \\
\text { water }\end{array}$ & Culture and colony blots & V. cholerae $\mathrm{O} 1$ & NR & $0.45 \%$ & NR & $\begin{array}{l}\text { Huq et al., } \\
\quad 2005\end{array}$ \\
\hline $\begin{array}{l}\text { Burkina } \\
\text { Faso }\end{array}$ & NR & $\begin{array}{l}\text { Channel } \\
\text { water }\end{array}$ & Culture & V. cholerae & NR & $10 \%$ & NR & $\begin{array}{c}\text { Traoré et al., } \\
2014\end{array}$ \\
\hline $\begin{array}{l}\text { Burkina } \\
\text { Faso }\end{array}$ & NR & $\begin{array}{l}\text { Reservoir } \\
\text { water }\end{array}$ & Culture & V. cholerae & NR & $10 \%$ & NR & $\begin{array}{c}\text { Traoré et al., } \\
2014\end{array}$ \\
\hline China & NR & Pearl River & $\begin{array}{c}\text { Immuno-fluorescent-Aggregation } \\
\text { Assay }\end{array}$ & V. cholerae & NR & $19.9 \%$ & NR & $\begin{array}{l}\text { Wang et al., } \\
\quad 2010\end{array}$ \\
\hline China & NR & Pearl River & Real Time PCR & V. cholerae & NR & $29.5 \%$ & NR & $\begin{array}{l}\text { Wang et al., } \\
\quad 2010\end{array}$ \\
\hline Egypt & $\begin{array}{l}2005 \\
\text { to } \\
2007\end{array}$ & $\begin{array}{l}\text { River Nile } \\
\text { (Rossita } \\
\text { branch) }\end{array}$ & Culture & V. cholerae & NR & $66.6 \%$ & NR & $\begin{array}{l}\text { El-Lathy, } \\
2009\end{array}$ \\
\hline Egypt & $\begin{array}{l}2005 \\
\text { to } \\
2007\end{array}$ & $\begin{array}{l}\text { Qarun } \\
\text { Lake }\end{array}$ & Culture & V. cholerae & NR & $6 \%$ & NR & $\begin{array}{l}\text { El-Lathy, } \\
2009\end{array}$ \\
\hline Egypt & NR & $\begin{array}{l}\text { Agriculture } \\
\text { drain }\end{array}$ & Culture & V. cholerae & $100 \mathrm{ml}$ & NR & 10 to $1.0 \mathrm{E}+03$ & $\begin{array}{l}\text { Hassanin et } \\
\text { al., } 2013\end{array}$ \\
\hline India & NR & $\begin{array}{l}\text { Surface } \\
\text { water }\end{array}$ & PCR & $\begin{array}{l}\text { V. colerae non- } \\
\quad \mathrm{O} 1\end{array}$ & NR & $40 \%$ & NR & $\begin{array}{l}\text { Yadava et al., } \\
2013\end{array}$ \\
\hline Iran & 2001 & $\begin{array}{l}\text { Gorgan } \\
\text { river }\end{array}$ & Culture & $\begin{array}{l}\text { V. cholerae non- } \\
\quad \mathrm{O} 1\end{array}$ & NR & $84.2 \%$ & NR & $\begin{array}{l}\text { Amirmozafari } \\
\text { et al., } 2005\end{array}$ \\
\hline Iran & 2001 & $\begin{array}{l}\text { Gorgan } \\
\text { river }\end{array}$ & Culture & V. cholerae $\mathrm{O} 1$ & NR & $13 \%$ & NR & $\begin{array}{l}\text { Amirmozafari } \\
\text { et al., } 2005\end{array}$ \\
\hline Iran & 2001 & $\begin{array}{l}\text { Gonbad } \\
\text { surface } \\
\text { water }\end{array}$ & Culture & $\begin{array}{l}\text { V. cholerae non- } \\
\quad \mathrm{O} 1\end{array}$ & NR & $75 \%$ & NR & $\begin{array}{l}\text { Amirmozafari } \\
\text { et al., } 2005\end{array}$ \\
\hline Italy & 1995 & River & $\begin{array}{l}\text { Hybridization, Restriction } \\
\text { Fragment Length } \\
\text { Polymorsphism }\end{array}$ & $\begin{array}{l}\text { V. cholerae non- } \\
\quad \mathrm{O} 1\end{array}$ & $200 \mathrm{~mL}$ & $\begin{array}{c}82.7 \% \\
(124 / 150)\end{array}$ & NR & $\begin{array}{c}\text { Caldini et al., } \\
1997\end{array}$ \\
\hline $\begin{array}{l}\text { Italian } \\
\text { Adriatic } \\
\text { coast }\end{array}$ & 1995 & $\begin{array}{l}\text { Metauro } \\
\text { river }\end{array}$ & Culture & $\begin{array}{l}\text { V. cholerae Non- } \\
\text { O1 }\end{array}$ & $100 \mathrm{~mL}$ & $\begin{array}{c}7 \% \\
(3 / 43)\end{array}$ & NR & $\begin{array}{l}\text { Barbieri et } \\
\text { al., } 1999\end{array}$ \\
\hline $\begin{array}{l}\text { Italian } \\
\text { Adriatic } \\
\text { coast }\end{array}$ & 1995 & $\begin{array}{l}\text { Foglia } \\
\text { river }\end{array}$ & Culture & $\begin{array}{l}\text { V. cholerae Non- } \\
\quad 01\end{array}$ & $100 \mathrm{~mL}$ & $\begin{array}{c}10 \% \\
(6 / 60)\end{array}$ & NR & $\begin{array}{l}\text { Barbieri et } \\
\text { al., } 1999\end{array}$ \\
\hline Mozambique & NR & $\begin{array}{l}\text { Surface } \\
\text { water }\end{array}$ & PCR and DFA & V. cholerae $\mathrm{O} 1$ & NR & $32.1 \%$ & NR & $\begin{array}{l}\text { Du Preez et } \\
\text { al., } 2010\end{array}$ \\
\hline South Africa & NR & River & PCR & V. cholerae & NR & $33 \%$ & NR & $\begin{array}{l}\text { Du Preez et } \\
\text { al., } 2003\end{array}$ \\
\hline South Africa & $\begin{array}{l}2003 \\
\text { to } \\
2004\end{array}$ & $\begin{array}{l}\text { Surface } \\
\text { water }\end{array}$ & Culture & V. cholerae & NR & $100 \%$ & NR & $\begin{array}{l}\text { Momba et } \\
\text { al., } 2006\end{array}$ \\
\hline South Africa & $\begin{array}{l}2003 \\
\text { to } \\
2004\end{array}$ & $\begin{array}{l}\text { Surface } \\
\text { water }\end{array}$ & PCR & $\begin{array}{l}\text { Toxigenic } V . \\
\text { cholerae }\end{array}$ & NR & $25 \%$ & NR & $\begin{array}{l}\text { Momba et } \\
\text { al., } 2006\end{array}$ \\
\hline South Africa & NR & $\begin{array}{l}\text { Crocodile, } \\
\text { komati and } \\
\text { Gutshwa } \\
\text { rivers }\end{array}$ & Culture and PCR & V. cholerae & NR & $17 \%$ & NR & $\begin{array}{c}\text { Madoroba } \\
\text { and Momba, } \\
2010\end{array}$ \\
\hline USA & $\begin{array}{l}1998 \\
\text { to } \\
2000\end{array}$ & $\begin{array}{l}\text { Estuarine } \\
\text { water }\end{array}$ & $\begin{array}{c}\text { DFA (Direct fluorescent- } \\
\text { antibody } \\
\text { Assay) }\end{array}$ & V. cholerae $\mathrm{O} 1$ & $250 \mathrm{~mL}$ & $\begin{array}{c}23.8 \% \\
(98 / 412)\end{array}$ & NR & $\begin{array}{l}\text { Louis et al., } \\
\quad 2003\end{array}$ \\
\hline
\end{tabular}

${ }^{\mathrm{a}}$ CFU: Colony Forming Unit; ${ }^{\mathrm{b}} \mathrm{MPN}$ : Most Probable Number; ${ }^{\mathrm{c}} \mathrm{NR}$ : Not Reported 


\subsubsection{Groundwater}

In India during the endemic cholera period, groundwater contaminated with sewage in Delhi was found to be responsible for the epidemic of $V$. cholerae (Pathak et al., 1993). An investigation of public water supply systems in south India in mid-1994 and after the endemic period in late 1992 and early 1993 resulted in the isolation of $V$. cholerae 0139 from one of the wells supplying the town, the central overhead tank, and domestic taps connected to the public supply (Ramakrishna et al., 1996). There was a need for adequate treatment of the water supply to control the cholera outbreak. Moreover, it was reported in 1994 that the cholera outbreak may have been associated with bottled water taken from a contaminated well. Vibrio cholerae is normally sensitive to chlorine, but may aggregate and assume a "rugose" form that is much more resistant to this disinfectant (Rice et al., 1993).

In South Africa, Momba et al. (2006) collected underground water samples from a borehole using a rotary hand pump, which is connected to a standpipe, and also from the Ngqele, Njwaxa and Ngwenya communities who receive their drinking water directly from standpipes, which are connected to the boreholes. Although all the boreholes are covered, they are surrounded by animal excreta and all of them are located close to pit latrines (with the exception of the Dyamala borehole). Results of this study revealed the presence of $V$. cholerae in all groundwater samples and $25 \%$ of all isolates had toxigenic genes. The authors concluded that groundwater could be a vehicle for the transmission of cholera. Table 9 depicts the occurrence of Vibrio spp. and/or biotypes in groundwater.

Table 9. Occurrence in ground water

\begin{tabular}{lccccc}
\hline Area & Microorganism & Matrix & $\begin{array}{c}\text { Detection } \\
\text { Method }\end{array}$ & $\begin{array}{c}\text { Percent } \\
\text { Positive } \\
\text { (\# of } \\
\text { Samples) }\end{array}$ & Reference \\
\hline India & V. cholerae 0139 & $\begin{array}{c}\text { Wells } \\
\text { Hand pump } \\
\text { water }\end{array}$ & Culture & $54 \%$ & Ramakrishna et al., 1996 \\
India & V. cholerae non-O1 & PCR & $20 \%$ & Yadava et al., 2013 \\
$\begin{array}{l}\text { South } \\
\text { Africa }\end{array}$ & V. cholerae & Ground water & Culture & $100 \%$ & Momba et al., 2006 \\
$\begin{array}{l}\text { South } \\
\text { Africa }\end{array}$ & Toxigenic V. cholerae & Ground water & PCR & $25 \%$ & Momba et al., 2006
\end{tabular}

aPeriod of study was 1994, Sample Volume 5L

\subsubsection{Drinking water}

For many decades, access to safe water supply and improved sanitation has received considerable attention in policies of the United Nations (UN) and collaborative programs with member states; raising awareness about water, stimulating debate and focusing on the dangers that arise from access to an unimproved water supply. While treated drinking water supply to each house may be a normal situation in developed countries, in contrast, the concept of access to both clean water and improved sanitation is not yet the rule in developing countries. Communities, mainly those in rural areas are prone to use any available water sources for multiple purposes including drinking and cooking. As a result, waterborne infections are found to be common in drinking water sources, causing more than 1.5 million children a year to die from diarrheal diseases (Fenwick, 2006). The mortality of water-associated diseases exceeds 5 million people per year. Of these, more than $50 \%$ of infections are linked to microbial intestinal infections, with cholera standing out in the first place (WHO, 2008a). Hence the isolation of $V$. cholerae from drinking water has alarming implications in the developing world. Also, the use of unsafe drinking water will continue to escalate the number of the cholera outbreaks in many developing countries. Possibly protective for cholera and other gastrointestinal infections, is drinking water quality monitored for Escherichia coli, but not when other total or thermotolerant coliforms are used (Gruber et al. 2014). Overall, Table 10 provides examples of Vibrio spp. and/or cholera biotype occurrence in drinking water. 
Table 10. Occurrence in drinking water

\begin{tabular}{lcccc}
\hline Area & Matrix & $\begin{array}{c}\text { Percent Positive } \\
\text { (\# of Samples) }\end{array}$ & Detection Method & Reference \\
\hline Bangladesh $^{\mathrm{a}}$ & Tap water & $12.5 \%$ & NR $^{\mathrm{b}}$ & Haque et al., 2013 \\
India $^{\mathrm{c}}$ & Potable water & $37 \%$ & Immuno- & Goel et al., 2005 \\
Iran & Tap water & $2 \%$ & PCR & Momtaz et al., 2013 \\
Pakistan $_{\text {Sudan }^{\mathrm{d}}}$ & Drinking water & $28 \%$ & Culture & Shar, 2010 \\
& Drinking water & $0.25 \%$ & NR & Payment et al., 1997
\end{tabular}

${ }^{\mathrm{a}}$ Microorganism O1(Ogawa); ${ }^{\text {} N R: ~ N o t ~ R e p o r t e d ; ~}{ }^{\mathrm{C}}$ Microorganism V. cholerae O1; ${ }^{\mathrm{d}}$ Period of study is 1993 to 1994.

\subsubsection{Seawater}

Pollution of marine waters by $V$. cholerae is primarily due to the disposal of wastewater or inadequately treated wastewater effluents into estuarine waters, to offshore disposal via sewage outfalls, and to rivers contaminated with inadequately treated wastewater effluents. Microbiological examination of coastal waters located near sewage outfalls showed the presence of $V$. cholerae (Grimes et al., 1984). The coastal waters have been considered as an important reservoir of $V$. cholerae (Colwell et al., 1981). Many authors also detected $V$. cholerae in seawater and other environmental sources around the world, both in cholera-endemic and in cholera-free areas (Kaysner et al., 1987; Huq and Colwell, 1996; Jesudason et al., 2000; Huq et al., 2001) (Table 11).

Table 11. Occurrence in seawater

\begin{tabular}{|c|c|c|c|c|c|}
\hline Area & Microorganism & Matrix & $\begin{array}{l}\text { Detection } \\
\text { Method }\end{array}$ & $\begin{array}{c}\text { Percent } \\
\text { Positive } \\
\text { (\# of } \\
\text { Samples) }\end{array}$ & Reference \\
\hline Azerbaijan & Non toxigenic $V$. cholerae $\mathrm{O} 1$ & Captian sea & Culture/ PCR & $50 \%$ & Rashid et al., 2013 \\
\hline Brazil & $\begin{array}{c}\text { Toxigenic } V \text {. cholerae non } \mathrm{O} 1 \\
\text { and non } 0139\end{array}$ & Sea water & PCR & $11 \%$ & Rivera et al., 2001 \\
\hline India & V. cholerae & Coastal water & Culture & $73 \%$ & Ouseph et al., 2009 \\
\hline Hong Kong & V. cholerae & Marine water & m-PCR & $89 \%$ & Kong et al., 2002 \\
\hline $\begin{array}{l}\text { Multiple } \\
\text { Countries }^{\mathrm{a}}\end{array}$ & $\begin{array}{l}\text { V. cholerae non } 01 \text { and non } \\
\text { O139 }\end{array}$ & Sea water & Culture/ PCR & $\mathrm{NR}^{\mathrm{b}}$ & Rivera et al., 1995 \\
\hline Peru & V. cholerae & Coastal water & PCR & $50 \%$ & Lipp et al., 2003 \\
\hline Peru & V. cholerae $\mathrm{O} 1$ & Coastal water & PCR & $36 \%$ & Lipp et al., 2003 \\
\hline Peru & Toxigenic $\mathrm{O} 1$ & Coastal water & PCR & $55.5 \%$ & Lipp et al., 2003 \\
\hline USA & V. cholerae non $\mathrm{O} 1 / 0139$ & $\begin{array}{l}\text { Recreational } \\
\text { seawater }\end{array}$ & Culture & $51 \%$ & Kwon, 2010 \\
\hline
\end{tabular}

${ }^{a}$ Brazil, Peru, Mexico, India with a period of study of 1977 to 1991; ${ }^{b}$ NR: Not Reported

\subsubsection{Sewage sludge}

Although no data have reported reported the occurrence of $V$. cholerae in sewage sludge, this environment may have a similar health hazard effect as the municipal sewage effluents, as this pathogen could remain 
undetected in untreated sewage sludge. Land application of untreated sewage sludge can lead to the transport of pathogens and is thus a potential health and environmental hazard as sludge may be harbouring harmful microorganisms. Further research about the occurrence, persistence and presence of $V$. cholerae and their biotypes in sewage sludge is still required, especially in the most cholera-endemic areas.

2.2.9 Soils and sediments
No data on occurrence, persistence or presence of $V$. cholerae and biotypes in soil was identified. Several research studies have been focused on the detection of $V$. cholerae in sediment samples (Rivera et al., 1995, 2001; Du Preez et al., 2010). Du Preez et al. (2010) collected sediment samples in Beira/Mozambique. The samples were analysed for the presence of $V$. cholerae 01 and 0139 and thte former was only in three $(11.1 \%)$ of the 27 sediment samples (Table 12).

Table 12. Occurrence in soil

\begin{tabular}{lccccc}
\hline Area & Microorganism & Matrix & $\begin{array}{c}\text { Detection } \\
\text { Method }\end{array}$ & $\begin{array}{c}\text { Percent } \\
\text { Positive } \\
\text { (\# of } \\
\text { Samples) }\end{array}$ & Reference \\
\hline Brazil & V. cholerae non O1/non O139 & Sediments & PCR & NR $^{\text {a }}$ & Rivera et al., 1995 \\
Brazil & Toxigenic V. cholerae non & Sediments & PCR & $100 \%$ & Rivera et al., 2001 \\
Mozambique & O. cholerae O1 & Sediments & PCR & $11.1 \%$ Du Preez et al., 2010
\end{tabular}

${ }^{a}$ NR: Not Reported

\subsubsection{Irrigation water and crops}

Water contaminated by fecal matter has been used for irrigation purposes in many countries and leads to waterborne diseases. Cholera is no exception, and of particular concern when vegetable, salad and other crops are eaten raw and directly irrigated with raw wastewater. For example, the cholera outbreaks in Jerusalem in the 1970s were reported to have occurred as a result of the irrigation of salad vegetables directly with untreated wastewater (Shuval et al., 1986). Other case studies, which were carried out in Peru pointed out that cabbage irrigated with $V$. cholerae contaminated water acted as a vehicle for the spread of that pandemic cholera outbreak (Swerdlow et al., 1992).

Recently, after the cholera outbreaks in Haiti in 2010, a report was compiled by Cravioto and co-workers (2010) on the predisposing factors that led to the spread of the cholera outbreaks. It was found that the choleracontaminated water in the Meye Tributary System reached the Artibonite River junction in less than $8 \mathrm{~h}$ and flowed downstream in another 1 to 2 days to a dam and a canal system widely used for irrigation throughout the Artibonite River Delta. The cholera outbreak was mainly attributed to the contaminated river water used for irrigation. The infection was mainly noted among young age groups between 20 and 24 years old. An increased risk of cholera transmission was reported in agricultural workers exposed to Artibonite River irrigation water in the rice paddies and fields.
After an outbreak of cholera in Bangladesh, high counts of $V$. cholerae were recorded on aquatic plants. The results of the experimental study showed that the numbers of $V$. cholerae suspended in the water had decreased, but the pathogens attached chiefly to the surface of the aquatic plants. After 5 days of experiment a 300-fold higher concentration of $V$. cholerae was found in the root system of these plants than in the surrounding water (Feikin et al., 2010). Spira et al. (1981) reported that the free-floating aquatic plants or parts of the plants act as a vehicle for the spread of $V$. cholerae or as a reservoir in inter-epidemic phases of the disease.

\subsubsection{In fish and shellfish}

The significance of fish and shellfish as a vehicle of cholera infection has long been recognized. Fishes are usually contaminated with $V$. cholerae when the surrounding water is contaminated by the sewage or other environmental water sources containing toxigenic strains. For example in Japan as early as 1886 and in the Philippines in 1908, raw fish consumption was associated with cholera outbreaks (Donitz, 1892; Heiser, 1908; Maheshwari et al., 2011).

Also, salted, frozen or inadequately cooked seafood has been highly implicated in the spread of cholera (Merson et al., 1977; Maheshwari et al., 2011). V. cholerae isolated from salted raw fish was found to be responsible for cholera outbreaks on Guam during 1974 (Kuberski et al., 1979). V. cholerae $\mathrm{O} 1$ was found in $0.2 \%$ of raw fishery products, whereas $V$. cholerae non-O1 was detected in $26.3 \%$ of raw 
and $12.14 \%$ of frozen fish products on Kerala and Tamil Nadu coasts during 1986 to 1987 (Varma et al., 1989). Feldhusen (2000) reported that raw fish was primarily implicated epidemiologically as a source of transmission of $V$. cholerae in the South American epidemic in 1991. Fish samples from freshwater as well as marine water carry $V$. cholerae and it has been reported that fish intestines contained $V$. cholerae counts of $5 \times 10^{3} \mathrm{CFU} / \mathrm{g}$ (Senderovich et al., 2010). In fact, it has been shown that toxigenic $V$. cholerae $\mathrm{O} 1$ can survive refrigeration and freezing in food supplies shipped internationally, therefore an epidemic strain may travel far from its original endemic location (CDC, 1991).
Recently, during the Haiti cholera outbreak in 2010, Hill et al. (2011) collected nine seafood samples - five along the coast between Saint-Marc port and Grand Saline (1 site) and four from Port-au-Prince port (3 sites). They isolated $V$. cholerae 01 Ogawa ctxA-positive strains from one mixed seafood sample containing multiple vertebrate fish and one crab, in addition to a bivalve sample containing multiple species. Moreover by proceeding to sequencing analyses, they found the isolated toxigenic $V$. cholerae strains matching the isolated strains from infected people during the endemic period. Table 13 summarises the occurrence of $V$. cholerae in fish and shellfish.

Table 13. Occurrence in fish and shellfish

\begin{tabular}{|c|c|c|c|c|c|c|}
\hline Area & Microorganism & Matrix & $\begin{array}{l}\text { Detection } \\
\text { Method }\end{array}$ & $\begin{array}{c}\text { Percent } \\
\text { Positive } \\
\text { (\# of } \\
\text { Samples) } \\
\end{array}$ & $\begin{array}{l}\text { Concentration } \\
\text { Average } \mathrm{CFU}^{\mathrm{a}} / \mathrm{g}\end{array}$ & Reference \\
\hline Brazil & $\begin{array}{l}V . \text { cholerae non } 01 / \text { non } \\
\text { O139 }\end{array}$ & Mussels & Culture/PCR & $\mathrm{NR}^{\mathrm{b}}$ & NR & $\begin{array}{l}\text { Matte et al., 1994; } \\
\text { Rivera et al., 1995 }\end{array}$ \\
\hline Brazil & $\begin{array}{c}\text { Toxigenic } V \text {. cholerae non } \\
\text { O1/non } 0139\end{array}$ & Mussels & PCR & $100 \%$ & NR & Rivera et al., 2001 \\
\hline Haiti $^{\mathrm{c}}$ & $\begin{array}{c}\text { Toxigenic } V . \text { cholerae } \mathrm{O} 1 \\
\text { Ogawa }\end{array}$ & Sea food & PCR & NR & NR & Hill et al., 2011 \\
\hline NR & V. cholerae $\mathrm{O} 1$ & Raw fish & NR & $0.2 \%$ & NR & Verma et al., 1989 \\
\hline NR & V. cholerae non $\mathrm{O} 1$ & Raw fish & NR & $26.3 \%$ & NR & Verma et al., 1989 \\
\hline NR & V. cholerae non $\mathrm{O} 1$ & Frozen fish & NR & $12.1 \%$ & NR & Verma et al., 1989 \\
\hline NR & V. cholerae & $\begin{array}{c}\text { Fish } \\
\text { intestine }\end{array}$ & NR & NR & 10 to $1.0 \mathrm{E}+05$ & $\begin{array}{c}\text { Senderovich et al., } \\
2010\end{array}$ \\
\hline
\end{tabular}

${ }^{\mathrm{a}}$ CFU: Colony Forming Unit; ${ }^{\mathrm{b}}$ NR: Not Reported; ${ }^{\mathrm{c}}$ Period of study 2010

\subsubsection{Air}

No data on the occurrence, persistence or presence of $V$. cholerae was directly identified for air. Nonetheless, several researchers have isolated Vibrio spp. and/or $V$. cholerae from flying insects that spent a part of their life cycle in water (Broza and Halpern, 2001; Halpern et al., 2003; Hassanain et al., 2013).

An examination of the geographic distribution of three cholera outbreaks showing their association with the wind direction was done by the Paz and Broza (2007). These authors found the following: a) the progress of $V$. cholerae O1 biotype El Tor in Africa during 1970-1971; b) again in 2005-2006; and c) the rapid spread of $V$. cholerae 0139 over India during 1992-1993. In another study on the possible influence of the wind direction on windborne dissemination by flying insects, which may serve as vectors, Paz and Broza (2007) established that winds supported the progress of $V$. cholerae throughout continents. This analysis supports the theory stipulating that aeroplankton (the tiny life forms that float in the air and that may be caught and carried upward by the wind, landing far from their origin) carry the cholera bacteria from one waterbody to the neighbouring one. In addition, the authors pointed out that these findings may improve the understanding of how climatic factors are involved in the rapid distribution of new strains throughout a vast continental area. Awareness of the aerial transfer of $V$. cholerae may, therefore, assist health authorities in improving the prediction of the disease's geographic dissemination (Paz and Broza (2007).

\subsection{Persistence and survival data}

Vibrio cholerae are able to survive in seawater and in some aquatic environments for months to years, and are thought to be part of the autochthonous microbiota in association with zooplankton (copepods). Seasonal fluctuations are often associated with changing nutrient concentrations; for example, the rainfall runoff is generally higher during spring/autuNA and in coastal and estuarine areas. This can lead to high zooplankton blooms (Huq et al., 2005), and as their exoskeleton contains chitin, V. cholerae ability to produce chitinases enables them to decompose 
zooplankton and easily infect animals that feed on this zooplankton (Alam et al., 2006). Depaola (1981) indicated that infected seafoods, especially clams and oysters, harbour $V$. cholerae for weeks, even if refrigerated. Moreover, Huq et al. (1983) found that $V$. cholerae can rapidly multiply in crabs at ambient temperature, and some cells may maintain infectivity even after immersion in boiling temperature for less than 10 minutes or at steaming temperatures for less than 30 minutes.

Also, $V$. cholerae is able to infect and survive within free-living protozoa, so providing a vehicle for spreading this pathogen through the aquatic environment (Thom et al., 1992; Brown and Barker, 1999). Environmental strains of $V$. cholerae can persist intracellularly in a range of amoebae (Abd et al., 2004, 2005; Jain et al., 2006). Several studies have established that the growth of $V$. cholerae is boosted when it is linked with free-living amoeba, and this explains the role of amoeba as environmental reservoirs of V. cholerae (Thom et al., 1992; Sandström et al., 2010; Valeru et al., 2012). In addition to its survival within amoebic trophozoites, $V$. cholerae cells have been found in the stress-resistant cysts formed by amoeba, providing protection from environmental degradation (Thom et al., 1992; Abd et al., 2004). Consequently, amoeba cysts could possibly facilitate the spread of cholera (Winiecka-Krusnell and Linder, 2001).

Vibrio cholerae can survive for hours or even weeks in water contaminated with organic material and at a $\mathrm{pH}$ ranging 6 to 9 , but is susceptible to desiccation, boiling, chloride, disinfection, and antibiotics (Valdespino and García-García, 2011). For example, V. cholerae 01 can survive in dechlorinated drinking water for 10 days with iron oxide and organic material (Joseph and Bhat, 2000). Djaouda et al. (2013) studied the ability of $V$. cholerae to survive or grow in unfiltered-autoclaved, filtered-nonautoclaved, and filtered-autoclaved well waters and they found that $V$. cholerae cells decreased over time, but surviving cells persisted for a longer period in filtered-nonautoclaved water. Vital et al. (2007) studied the growth of $V$. cholerae $\mathrm{O} 1 \mathrm{El}$ Tor Ogawa in autoclaved and filtered freshwaters and reported growth in river water, lake water and effluent of a wastewater treatment plant. Moreover they suggested that assimilable organic carbon (AOC) was a key parameter governing its growth. In an experimental system, Rajkowski et al. (1996) demonstrated $V$. cholerae grow in reconditioned wastewater containing sufficient nutrients but free from competing microbiota at temperatures ranging from 5 to $42^{\circ} \mathrm{C}$.

The association between $V$. cholerae occurrence and salinity seems to be variable. While some studies reported a significant correlation (Singleton et al., 1982; Johnson et al., 2010), others revealed a lack of correlation between the occurrence of $V$. cholerae and salinity (Johnson et al., 2012). Hence, growth is likely impacted by other (biotic) factors.

In nutrient limited environments, $V$. cholerae can enter a state of starvation and this may result in the cells nongrowing, but being culturable (Lutz et al., 2013). In a recent laboratory study by Jubair et al. (2012), the longterm starvation survival of $V$. cholerae was demonstrated for 700 days. The authors advocate for the term "persister phenotype" to differentiate starved cells from the viable but non- culturable (VBNC) state. They observed that the presence of phosphate and chitin enhanced the growth of persister cells. Furthermore, they stipulated that both nutrients are important and highlight their prominence for $V$. cholerae survival. In another study on the behaviour of $V$. cholerae starving for 40 days, it was reported that chitin attachment ligands were maintained (Pruzzo et al., 2003). Aulet et al. (2007) described the sporadic isolation of Vibrio cholerae from rivers in Tucumán, Argentina, since the outbreak in 1991. In this study, $V$. cholerae was isolated and detected using conventional culture methods and direct immunofluorescence (DFA-VNC) to detect VBNC $V$. cholerae 01 . Results revealed the detection of $V$. cholerae $\mathrm{O} 1$ in 38 of the 54 water samples analyzed.

Survival of toxigenic $V$. cholerae in the environment during epidemics is not often detected by culture-based methods (Islam et al., 1994), presumably due to its ability to survive in a VBNC state (Alam et al., 2006). It is important to note that toxigenic $V$. cholerae cells may still be viable and able to induce disease but is not easy to recover on the specific culture media (Colwell, 1996). Vibrio cholerae have been detected using PCR, in both surface water and groundwater (Momba et al., 2006; Madoroba and Momba, 2010). Realizing that most studies do not report on the presence of VBNC cells, Table 14 depicts the survival of $V$. cholerae in various environments.

Table 14. Persistence/Survival

\begin{tabular}{lccc}
\hline Matrix & Survival Days & Experimental Conditions & Reference \\
\hline Dairy Products & More than two weeks & NR $^{\text {a }}$ & Felsenfeld, 1967 \\
Clams and oysters & Several weeks & At both room temperature and & Depaola, 1981 \\
Cooked chicken & More than 16 hours & NR & Kolvin and Roberts, 1982 \\
Crabs & Rapid multiplication & At ambient temperature & Huq et al., 1983 \\
Crabs & Not completely killed & By 10 min boiling or 30 min & Huq et al., 1983
\end{tabular}




\begin{tabular}{|c|c|c|c|}
\hline Matrix & Survival Days & Experimental Conditions & Reference \\
\hline Aquatic algae & More than 15 months & $\begin{array}{l}\text { Inside the mucilaginous sheath } \\
\text { of the Anabaena variabilis }\end{array}$ & Islam et al., 1990 \\
\hline Surface and Drinking water & $1 \mathrm{~h}$ to 13 days & NR & Pesigan, 1965 \\
\hline Wastewater & Well grown & $\begin{array}{l}\text { At temperatures from } 5 \text { to } \\
\qquad 42^{\circ} \mathrm{C} \text {. }\end{array}$ & Rajkowski et al., 1996 \\
\hline Fresh and wastewater ${ }^{b}$ & $<30$ but usually & At 20 to $30^{\circ} \mathrm{C}$ & EPA, 1999 \\
\hline Crops & $<5$ but usually $<2$ days & At 20 to $30^{\circ} \mathrm{C}$ & EPA, 1999 \\
\hline Soil & $\begin{array}{c}<120 \text { but usually }<50 \\
\text { days }\end{array}$ & At 20 to $30^{\circ} \mathrm{C}$ & EPA, 1999 \\
\hline $\begin{array}{l}\text { Dechlorinated drinking } \\
\text { water }^{c}\end{array}$ & 10 days & $\begin{array}{l}\text { With iron oxide and organic } \\
\text { material }\end{array}$ & Joseph and Bhat, 2000 \\
\hline Fresh water & 30 days & NR & Carr, 2001 \\
\hline Salt water & More than 285 days & NR & Carr, 2001 \\
\hline Soil & $<20$ days & NR & Carr, 2001 \\
\hline Crops & $<5$ & NR & Carr, 2001 \\
\hline $\begin{array}{l}\text { Carriers People shedding in } \\
\text { their stool }^{\mathrm{d}}\end{array}$ & 4 to 15 months & NR & Nevondo and Cloete, 2001 \\
\hline Surface water & Few hours to 14 days & NR & Nevondo and Cloete, 2001 \\
\hline Industrially polluted water & 39 days & $\begin{array}{l}\mathrm{pH} 8 \text { and } \mathrm{Fe} \text { conc. } 0.5 \text { to } \\
1.0 \mathrm{mg} / \mathrm{L}\end{array}$ & Patel et al., 2004 \\
\hline Industrially polluted water ${ }^{\mathrm{f}}$ & 35 days & pH 8 and Fe conc. 0.5 & Patel et al., 2004 \\
\hline Industrially polluted water ${ }^{g}$ & 26 days & pH 8 and Fe conc. 0.5 & Patel et al., 2004 \\
\hline $\begin{array}{l}\text { Contaminated water with } \\
\text { organic matter }\end{array}$ & Few hours to weeks & $\mathrm{pH}$ between 6 and 9 & $\begin{array}{l}\text { Valdespino and Garcla- } \\
\text { Garcla, } 2011\end{array}$ \\
\hline In low nutrient environment & 700 days & NR & Jubair et al., 2012 \\
\hline
\end{tabular}

${ }^{\mathrm{a}}$ NR: Not Reported; ${ }^{\mathrm{b}}$ Persistence of $<10$ days; Microorganism are ${ }^{\mathrm{c}} V$. cholerae $01 ;{ }^{\mathrm{d}}$ Toxigenic V. cholerae ; $\mathrm{V}$. cholerae non-O1; ${ }^{\mathrm{f}}$. cholerae $\mathrm{O} 1 \mathrm{El}$ Tor; ${ }^{\mathrm{g}} \mathrm{V}$. cholerae $\mathrm{O} 1 \mathrm{Classical}$

\subsection{Reduction by sanitation management}

Human excreta and the lack of adequate personal and domestic hygiene have been a great concern in the spread of many communicable diseases, including cholera. Suitable excreta disposal practices and minimum levels of personal and domestic hygiene are essential for preventing the transmission of diseases and protecting the public health. Safe excreta disposal and handling are considered as the first line of defence to prevent enteric pathogens from entering the environment (Carr, 2001). As described in other chapters, the safe use of human excreta means implementing adequate excreta management technologies in a way that reduces the exposure dose of pathogens to very low numbers. This section discusses various ways of managing sanitation for the reduction of $V$. cholerae and surrogates to demonstrate efficacy.

\subsection{Excreta and Wastewater Treatment}

\subsubsection{Waterless sanitation management}

Globally, 2.5 billion people do not have access to improved sanitation facilities. Southern Asia and subSaharan Africa continue to have the lowest levels of coverage. In contrast to Southern Asia, in sub-Saharan Africa the sanitation coverage of $30 \%$ reflects only a 5 percentage point increase since 1990. The number of people practising open defecation is still increasing in 26 of 44 countries in sub-Saharan Africa. Hence, application of any type of toilet is strongly related to hygiene behaviour change rather than acquisition of a physical toilet, be it a dry toilet or pour flush.

Experience with cholera cases suggests that developing region epidemics are closely related to poor environment status and lack of basic sanitation infrastructure. Cholera cases tend to increase with the onset of the rainy season, and conditions that permit the persistence of waterborne transmission. During the rainy season, where there is either no sewage disposal or working sewer system, rainfall runoff follows the slopes into the lower parts of towns where shallow wells could easily become contaminated by excreta (Fernandez et al., 2012). Improving water and sanitation infrastructure is critical to achieving the profound health gains brought by these systems elsewhere.

\subsubsection{Pit latrines, vault toilets, dry toilets}

Momba et al. (2006) reported $V$. cholerae and toxigenic 
$V$. cholerae at $100 \%$ and $25 \%$ respectively in underground water samples linked to pit latrines (with the exception of the Dyamala borehole). Although no specific studies have demonstrated the reduction of $V$. cholerae by pit latrine, evidence has shown that children using pit latrines in a shanty town in Brazil had 1.5 times fewer cases of diarrhoea compared to those practicing open defaecation (Gross et al., 1989). In Lesotho, children $<5$ years old using a latrine had 24 per cent fewer episodes of diarrhoea than those without a VIP latrine in their dwellings (Daniels et al., 1990). And in East Africa, 22 per cent of VIP latrine users were less likely to develop diarrhoea compared to those without toilet facilities (Thompson et al., 2001). Ecological sanitation such as composting latrines or dehydrating latrines with urine separation has been identified as a more economic and environmentally friendly alternative to traditional latrines or sewerage (Esrey et al., 1998). Nevertheless, little is known on their effectiveness in the reduction of $V$. cholere $a$ and the indicidence of cholerae in communities using these improved sanitation ssytems.

\subsubsection{Water-based sanitation}

\subsubsection{On-site systems}

Septic tanks have long been known to be an ineffective barrier for $V$. cholerae. For example, Flu (1921) conducted a study in Indonesia using five different septic tanks that were challenged with cultures containing an unspecified number of $V$. cholerae and detecting it in the effluent of one tank 24 hours after the challenge. In other studies the removal of $V$. cholerae $\mathrm{O} 1$ and non-O1 in Oxfam Sanitation Units was examined. The examined units were in a doublechambered septic tank consisting of two flexible butyl rubber containers with a total mean hydraulic retention time of 12 to 15 days. The study on the removal of $V$. cholerae 01 employed the effluent from the wards of the Cholera Research Laboratory in Dacca, Bangladesh. In view of the long retention time, removal was relatively poor, with only $1.7 \log _{10}$ being removed in the first tank and 1.05 $\log _{10}$ being removed in the second tank (overall removal 2.7 $\log _{10}$ ). The unit was monitored for two months (November and December); during this time the temperature of the wastewater fell by $10^{\circ} \mathrm{C}$ without affecting the removal of the $V$. cholerae. The conditions in the tanks were relatively inhospitable (anaerobic, with $\mathrm{pH}$ values of 6.3 to 6.7 and 40 to $90 \mathrm{mg} / \mathrm{L}$ of ammonia). The poor removal may have been attributable to short-circuiting. The removal of $V$. cholerae non-O1 was also studied in units in refugee camps. The removal of the $V$. cholerae non-O1 was comparable with the results of the other studies, with geometric mean removals of $2.7 \log _{10}$ and $1.48 \log _{10}$ in the two systems (Howard et al., 1975; Daniel and Lloyd, 1979; Daniel and Lloyd, 1980).

\subsubsection{Coupled environmental and engineered systems}

\subsubsection{Waste stabilization ponds}

In a case study of waste stabilization ponds in Northeast Brazil, Arridge (1995) found one log removal of bacterial indicators including faecal coliforms, faecal streptococci and Clostridium perfringens from 1300 to $700 \mathrm{MPN} / \mathrm{L}$, while $V$. cholerae 01 was reduced from 40 to $10 \mathrm{MPN} / \mathrm{L}$. Although the anaerobic ponds appear to be essential for high levels of $V$. cholerae removal, complete removal of this pathogen was not achieved. In another case study, the average percentage removal reached up to $2.1 \log _{10}$ for the final effluents of oxidation ponds of the wastewater treatment plant in El-Sadat City, Egypt (El-Lathy et al., 2009).

\subsubsection{Wetlands}

Generally little has been reported on the performance of wetlands in removing $V$. cholerae. Gutiérrez-Sarabia et al. (2004) evaluated the performance of a full-scale system with wetlands for slaughterhouse (abattoir) effluent treatment in the State of Hidalgo, Mexico. The treatment system consisted of a primary sedimentation tank, an anaerobic lagoon, and a constructed subsurface-flow wetland in series. In general, the treatment system achieved satisfactory pollutant removals, but the final effluent failed to meet the Mexican environmental regulations for faecal coliform counts, five-day biochemical oxygen demand $\left(\mathrm{BOD}_{5}\right)$ and total suspended solids (TSS). Coliform reductions in the overall system were high (of the order of $5 \log _{10}$ on average), whereas the coliform removal in the wetland was between 2 to $3.5 \log _{10}$. The treatment system was also effective for removing $V$. cholerae. Further laboratory tests with the wetland effluent suggested that post-treatment in a sand filter stage followed by disinfection with sodium hypochlorite $(\mathrm{NaOCl})$ could help meet the Mexican discharge regulations, particularly the criteria for coliforms and $\mathrm{BOD}_{5}$.

\subsubsection{Aerated lagoons and oxidation ditch}

Oxidation ditches are alternative processes to more expensive activated sludge treatment, being single-sludge wastewater treatment systems. They are capable of achieving carbon oxidation, nitrification and denitrification with a single biomass slurry. Although both aerated lagoons and oxidation ditches have been used for treating sewage, to date no data have been reported for their performance in removing $V$. cholerae.

\subsubsection{Wastewater treatment facilities}

A wastewater treatment system is a combination of physical, chemical and biological processes. Generally, conventional wastewater treatment consists of: (i) preliminary treatment (which includes screening and grit removal); (ii) primary treatment (which involves the removal of $0.15 \log _{10}$ to $0.3 \log _{10}$ of the suspended solids in a primary settling tank); (iii) secondary treatment also called biological treatment (which is usually a trickling filter or an activated sludge reactor); and finally, (iv) advanced treatment that can be found in some conventional wastewater treatments.

While in most studies, indicator bacteria (such as total coliforms, faecal coliforms and Escherichia coli) have been tested to ascertain the performance of these technologies 
for microbial quality of the effluent, little has been reported on the effectiveness of each process in removing $V$. cholerae. The discussion in this section mainly focuses on combined sewer overflows, trickling filter, activated sludge and disinfection processes.

\subsubsection{Combined sewer overflow lagoons}

Mariita and Okemo (2009) examined the presence of $V$. cholerae $\mathrm{O} 1$ in sewage lagoons around Kenyatta University. The sewage treatment plant was composed of two facultative ponds (primary and secondary) followed by two maturation ponds. Findings of this study revealed no log reduction for $V$. cholerae $\mathrm{O} 1$ after facultative ponds, and only one log reduction was observed after maturation ponds. Sewage effluent poses a great risk to farmers using it for irrigation downstream as well as to consumers of vegetables, such as cabbage, who use the fresh produce to prepare salads.

\subsubsection{Trickling filters}

Ngari et al. (2011) investigated the levels of $V$. cholerae at different stages of wastewater treatment at the Nakuru Town Sewage Treatment Plant, Kenya. The plant had two treatment lines, namely a trickling filter line (a combination of conventional/mechanical treatment units) and an anaerobic pond line (wastewater stabilization ponds only). The reduction rate of $V$. cholerae in the trickling filter line was $0.5 \log _{10}$ after facultative ponds, $4 \log _{10}$ after maturation ponds, $4 \log _{10}$ after passing through the rock filter, and $2.52 \log _{10}$ after application to the grass plot. In the anaerobic line, reduction of $V$. cholerae was as follows: $0.64 \log _{10}$ after anaerobic pond, $4 \log _{10}$ after facultative pond, $0.86 \log _{10}$ after maturation ponds, $0.58 \log _{10}$ after passing through the rock filter, and an apparent $>3 \log _{10}$ after application to the grass plot. Results showed that the facultative pond of the anaerobic pond line and the final maturation pond of the trickling filter line achieved the highest percentage removal of $V$. cholerae.

\subsubsection{Activated sludge system}

In South Africa a number of studies have been conducted to ascertain the effectiveness of activated sludge systems to remove $V$. cholerae from wastewater. A case study by Samie et al. (2009) determined the efficiency of 14 sewage treatment plants in the Mpumalanga Province. The treatment plant types included ponds, activated sludge and trickling filters followed by a chlorine disinfection step. The final effluent was used for irrigation and recycling purposes in four plants; all the other treatment plants discharged the effluent into the river or to the environment. The authors found that the most encountered potential bacterial pathogens belonged to Vibrio spp. and concluded the potential risk for a cholera outbreak in the province. The general reduction of Vibrio spp. by each plant was calculated based on the total number of isolates in the influent samples as well as in the effluent samples. Overall, the reduction of Vibrio spp. was found to be less than $60 \%$.

Dungeni et al. (2010) detected toxigenic V. cholerae in the final effluents of three of the four activated sludge treatment plants investigated: 35.3, 21.9 and $9.4 \%$ of the Baviaanspoort, Refilwe and Rayton effluent samples tested positive for $V$. cholerae, respectively. However, complete removal of $V$. cholerae occurred in the effluent of the Zeekoegat Wastewater Treatment Plant and this was attributed to the presence of a filtration process and suitable retention time. The introduction of a secondary treatment process such as filtration, or a much more efficient disinfection process, was therefore recommended to improve the performance of the wastewater treatment plants that fail to produce the effluent quality required (Dungeni et al., 2010). In their studies, Teklehaimanot et al. $(2014,2015)$ found that between 20 and $60 \%$ of samples tested positive for $V$. cholerae.

In Egypt, Abdel-Wahaab (1995) examined the efficiency of activated sludge treatment plants and found that up to 99.99\% removal of heterotrophic bacteria was achieved. In addition, faecal indicator bacteria, Staphylococcus spp., Salmonella enterica and $V$. cholerae, were completely removed, versus only 33\% removal of enteric viruses. Moreover, all helminth eggs were removed except hookworm eggs which were still present even after disinfection with chlorine. No significant removal was recorded for the protozoan parasites following treatment. It was then recommended that a slight to moderate restricted irrigation be applicable for the effluent reuse in irrigation, taking into consideration that sprinkler irrigation should not be applied. In another study in Egypt, El-Lathy et al. (2009) determined Vibrio spp. in the influent and effluent of activated sludge from the Zenin Wastewater Treatment Plant and oxidation pond in El-Sadat City in 2006 and 2007. They found that the average removal percentage reached between $2.7 \log _{10}$ and $2.1 \log _{10}$ for the activated sludge and oxidation pond, respectively.

\subsection{Disinfection as a tertiary or post-treatment of wastewater effluent}

Discharge of wastewater treatment plant effluents that contain any type of microorganism including $V$. cholerae may result in the pollution of water supply resource. Indicative levels of Vibrio spp. in secondary treated wastewater may range between $10^{4}$ and $10^{6}$ organisms $/ 100 \mathrm{~mL}$, depending on the treatment process (USEPA, 1992; Rose et al., 1995; Toze, 1997). The ultimate goal of wastewater disinfection is therefore to produce an effluent of such microbiological quality that minimal additional controls are required to manage public health, agricultural or environmental risks. It is important to mention that the quality of effluent depends on upon final use.

\subsubsection{Chlorine, combined, etc.}

Chlorine has been shown to be effective in killing $V$. cholerae. However, the effectiveness of chlorine is related to the bioavailability of the dose. Many studies have evaluated the effectiveness of chlorine to eliminate $V$. cholerae 01 . When the level of chlorine at $7 \mathrm{mg} / \mathrm{L}$ is applied for a specific time, viable cells were recovered. However, at $8 \mathrm{mg} / \mathrm{L}$ for that specific time, total culturability of $V$. 
cholerae was lost. Noting that chlorine efficacy is significantly reduced when organic matter is present or $\mathrm{pH}$ is $<6$ of greater than 9 .

In response to the disastrous outbreak of cholera in Peru during the 1990's, the Commission of the European Community recommended that all Peruvian factories producing fruit and vegetables for export should chlorinate their wastewater (EEC, 1991). In those countries where cholera persists, only a limited amount of money is available for the provision of sanitation. Therefore, it is important to consider the circumstances under which the removal of $V$. cholerae is warranted. To spend money to remove the $V$. cholerae when there is no need to do so may divert funds and administrative expertise from more pressing problems (Drasar and Forrest, 1996). It was found that $V$. cholerae was completely removed in the chlorinated final effluents of 14 sewage treatment plants in the Mpumalanga Province, South Africa (Samie et al., 2009). However, in many studies $V$. cholerae was detected in the chlorinated effluent of wastewater treatment plants (Dungeni et al., 2010; Teklehaimanot et al., 2014, 2015). Hence, it is critical to apply a satisfactory concentration $\mathrm{x}$ time disinfection (Refer to related chapter on treatment).

Dungeni et al. (2010) studied the effectiveness of four wastewater treatment plants that use chlorine for disinfection located in the vicinity of Pretoria, Gauteng Province, South Africa, in the removal of pathogenic bacteria including $V$. cholerae. They detected toxigenic $V$. cholerae in $75 \%$ of the investigated wastewater treatment plants (three out of four plants) despite high free chlorine residual concentrations in treated effluents. The residual chlorine level ranged between 0.03 and $1.60 \mathrm{mg} / \mathrm{L}$. Thus they suggested an upgrading of these wastewater treatment plants by including processes such as rapid sand filtration and UV disinfection, which have proved to be effective in the removal and inactivation of pathogenic bacteria.

Rice et al. (1993) studied the effect of chlorine on $V$. cholerae $\mathrm{O} 1$ and they found that $V$. cholerae $\mathrm{O} 1$ is able to shift between smooth and rugose colonial morphologies. Cultures of smooth $V$. cholerae strains were inactivated in less than $20 \mathrm{~s}$ at a concentration of $1.0 \mathrm{mg} / \mathrm{L}$ free chlorine in chlorine-demand free water. In contrast, with the cultures of rugose variants exposed to this concentration of chlorine, there was an initial rapid drop in viable counts, followed by persistence of a protected sub-population of cells. The authors stated that viable $V$. cholerae could still be recovered from rugose cultures even after exposure to $2.0 \mathrm{mg} / \mathrm{L}$ free chlorine for $30 \mathrm{~min}$. Preliminary studies suggest that resistance to killing by chlorine was due to formation of cell aggregates enclosed in a gelatinous mucoid material. Moreover, the $V$. cholerae rugose phenotype represents a fully virulent survival form of the organism that can persist in the presence of free chlorine.

\subsubsection{Ultraviolet}

Typical UV doses required for a 4-log inactivation of $V$. cholerae have been reported to be $0.65 \mathrm{~mJ} / \mathrm{cm}^{2}$ (Malley, 2000; USEPA, 2003). Some studies have shown that environmental populations of bacteria are less susceptible to UV than cultured organisms (Hijnen et al., 2006; Smeets et al., 2006). Hijnen et al. (2006) observed that the UV dosages required for $1,2,3$ and $4 \log$ inactivation of environmental $V$. cholerae were 2, 4, 7 and $9 \mathrm{~mJ} / \mathrm{cm}^{2}$, respectively. Table 15 depicts some treatment reduction of V. cholera.

Table 15. Treatment Reductions of $V$. cholerae

\begin{tabular}{|c|c|c|c|c|c|c|}
\hline Area & Treatment & $\begin{array}{l}\text { Treatment } \\
\text { Conditions }\end{array}$ & $\begin{array}{l}\text { Treatment } \\
\text { reduction }\end{array}$ & $\begin{array}{c}\text { Initial concentration } \\
\text { \& Subsequent } \\
\text { Concentration at } \\
\text { treatment time t }\end{array}$ & Methods & Reference \\
\hline $\begin{array}{l}\text { Northeast } \\
\text { Brazil }\end{array}$ & $\begin{array}{l}\text { Stabilization } \\
\text { pond }\end{array}$ & $\mathrm{NR}^{\mathrm{a}}$ & $0.12 \log _{10}$ & 40 to $10 \mathrm{MPN} / 100 \mathrm{~mL}$ & Culture & Arridge, 1995 \\
\hline $\begin{array}{l}\text { Egypt } \\
\text { (El-Sadat } \\
\text { City) }\end{array}$ & Oxidation pond & NR & $2.1 \log _{10}$ & $\begin{array}{c}2.6 \mathrm{E}+05 \text { to } 1.9 \mathrm{E}+03 \\
\mathrm{CFU} / 100 \mathrm{~mL}\end{array}$ & Culture & $\begin{array}{c}\text { El-Lathy et al., } \\
2009\end{array}$ \\
\hline Kenya & Maturation pond & $\begin{array}{c}\text { Low pH } \\
\text { Low } \\
\text { temperature }\end{array}$ & $0.7 \log _{10}$ & $\begin{array}{c}1.1 \mathrm{E}+03 \text { to } 2.2 \mathrm{E}+02 \\
\mathrm{CFU} / 100 \mathrm{~mL}\end{array}$ & $\begin{array}{l}\text { Culture and } \\
\text { biochemical } \\
\text { tests }\end{array}$ & $\begin{array}{c}\text { Mariita and } \\
\text { Okemo, } 2009\end{array}$ \\
\hline Kenya & Facultative pond & 10.3 to $28.4 \mathrm{oC}$ & $0.54 \log _{10}$ & NR & Culture & $\begin{array}{l}\text { Ngari et al., } \\
2011\end{array}$ \\
\hline Kenya & Maturation pond & 10.3 to $28.40 \mathrm{C}$ & $4 \log _{10}$ & NR & Culture & $\begin{array}{l}\text { Ngari et al., } \\
2011\end{array}$ \\
\hline Kenya & Anaerobic pond & 10.3 to $28.4 \mathrm{oC}$ & $0.64 \log _{10}$ & NR & Culture & $\begin{array}{c}\text { Ngari et al., } \\
2011\end{array}$ \\
\hline
\end{tabular}




\section{References}

Abakpa, G.O., Umoh, V.J. and Ameh, J.B. (2013). Occurrence of Vibrio cholerae in some households engaged in livestock farming in some parts of Zaria, Nigeria. Advances in Microbiology. 3, pp. 128-131.

Abdel-Wahaab, R. (1995). Wastewater treatment and reuse: environmental health and safety considerations. International Journal of Environmental Health Research. 5, pp. 35-46.

Abd, H., Weintraub, A. and Sandström, G. (2005). Intracellular survival and replication of Vibrio cholerae O139 in aquatic free-living amoebae. Environmental microbiology. 7, pp. 1003-1008.

Abd, H., Weintraub, A. and Sandström, G. (2004). Interaction between Vibrio cholerae and Acanthamoeba castellanii. Microbial Ecology in Health and Disease. 16, pp. 51-57.

Acosta, C.J., Galindo, C.M., Kimario, J., Senkoro, K., Urassa, H., Casals, C. et al. (2001). Cholera outbreak in southern Tanzania: Risk factors and patterns of transmission. Emerging Infectious Diseases. 7, pp. 583-587.

Akoachere, J.T.K. and Mbuntcha, C.K.P. (2014). Water sources as reservoirs of Vibrio cholerae 01 and non-O1 strains in Bepanda, Douala (Cameroon): relationship between isolation and physico-chemical factors. BMC Infectious Diseases. 14, pp. 421-431.

Alam, M., Islam, M.T., Rashed, S.M., Johura, F.T., Bhuiyan, N.A., Delgado, G. et al. (2012). Vibrio cholerae classical biotype strains reveal distinct signatures in Mexico. Journal of Clinical Microbiology. 50, pp. 2212-2216.

Alam, M., Sultana, M., Nair, G.B., Sack, R.B., Sack, D.A., Siddique, A.K. et al. (2006). Toxigenic Vibrio cholerae in the aquatic environment of Mathbaria, Bangladesh. Applied and Environmental Microbiology. 72, pp. 2849-2855.

Ali, M., Lopez, A.L., You, Y.A., Kim, Y.E., Sah, B., Maskery, B. et al. (2012). The global burden of cholera. Bulletin of the World Health Organization. 90, pp. 209-218A.

Ali, M., Nelson, A.R., Lopez, A.L. and Sack, D.A. (2015). Updated Global Burden of Cholera in Endemic Countries. PLOS Neglected Tropical Diseases. 9, pp. e0003832. doi: 10.1371/journal.pntd.0003832.

Amirmozafari, N., Forchesh, H. and Halakoo, A. (2005). Occurrence of pathogenic vibrios in coastal areas of Golestan Province in Iran. Archives of Razi Institute. 60, pp. 33-44.

Ansaruzzaman, M., Bhuiyan, N.A., Nair, B.G., Sack, D.A., Lucas, M., Deen, J.L. et al. (2004). Cholera in Mozambique, variant of Vibrio cholerae. Emerging Infectious Diseases. 10, pp. 2057-2069.

APHA (2012). Standard Methods for the examination of water and wastewater (22nd ed). American Public Health Association. Washington DC.

Arridge, H. (1995). Vibrio cholerae 01 and salmonellae removal compared with the die-off of faecal indicator organisms in waste stabilization pond in northeast Brazil. Water Science and Technology. 31, pp. 249.

Aulet, O., Silva, C., Fraga, S.G., Pichel, M., Cangemi, R., Gaudioso, C. et al. (2007). Detection of viable and viable nonculturable Vibrio cholerae $\mathrm{O} 1$ through cultures and immunofluorescence in the Tucumán rivers, Argentina. Revista da Sociedade Brasileira de Medicina Tropical. 40, pp. 385-390.

AWWA (2006). Manual of Water Supply Practices. (M48): Waterborne Pathogens. American Water Works Association. Denver, Colorado.

Azurin, J.C., Kobari, K., Alvero, M., Gomez, C.Z., Dizon, J.J., Nakano, E.I. et al. (1967). A long-term carrier of cholera: cholera Dolores. Bulletin of the World Health Organization. 37, pp. 745-749.

Bag, P.K., Bhowmik, P., Hajra, T.K., Ramamurthy, T., Sarkar, P., Majumder, M. et al. (2008). Putative Virulence Traits and 
Pathogenicity of Vibrio cholerae Non-01, Non-0139 Isolates from Surface Waters in Kolkata, India. Applied and Environmental Microbiology. 74, pp. 5635-5644.

Barbieri, E., Falzano, L., Fiorentini, C., Pianetti, A., Baffone, W., Fabbri, A. et al. (1999). Occurrence, diversity, and pathogenicity of halophilic Vibrio spp. and non-O1 Vibrio cholerae from estuarine waters along the Italian Adriatic coast. Applied and Environmental Microbiology. 65, pp. 2748-2753.

Barrett, T. and Feeley, J. (1994). Serologic Diagnosis of Vibrio cholerae 01 Infections. Vibrio cholerae and Cholera. (Wachsmuth, I., Blake, P. and Olsvik, O., ed.). ASM Press. Washington, DC. pp. 135-141. doi: 10.1128/9781555818364.ch10.

Bart, K.J., Khan, M. and Mosley, W.H. (1970). Isolation of Vibrio cholerae from nightsoil during epidemics of classical and El Tor cholera in East Pakistan. Bulletin of the World Health Organization. 43, pp. 421-429.

Barzilay, E.J., Schaad, N., Magloire, R., Mung, K.S., Boncy, J. and Dahourou, G.A. (2013). Cholera surveillance during the Haiti epidemic - the first 2 years. The New England Journal of Medicine. 368, pp. 599-609.

Baumann, P. and Baumann, L. (1984). Genus Photobacterium. Bergey's Manual of Systematic Bacteriology. Vol. 1 ed. (Krieg, N.R. and Holt, J.C., ed.). The Williams and Wilkins Co. Baltimore. pp. 539-545.

Bavishi, C. and DuPont, H.L. (2011). Systematic review: the use of proton pump inhibitors and increased susceptibility to enteric infection. Alimentary Pharmacology and Therapeutics. 34, pp. 1269-2681.

Bhaskar, N., Kinami, T., Park, S.B., Endo, Y. and Fujimoto, K. (2004). Occurrence of conjugated polyenoic fatty acids in seaweeds from the Indian Ocean. Abstract, Verlag der Zeitschrift für Naturforschung. 59, pp. 310-314.

Bhattacharya, S.K., Sur, D., Ali, M., Kanungo, S., Y You, A., Manna, B. et al. (2013). 5 year efficacy of a bivalent killed whole-cell oral cholera vaccine in Kolkata, India: a cluster-randomised, double-blind, placebo-controlled trial. The Lancet. Infectious Diseases. 13, pp. 1050-1056.

Bhutta, Z., Clemens, J., DeRoeck, D., Henkens, M., Kaper, J., Weiss, M. et al. (2009). Background Paper on the Integration of Oral Cholera Vaccines into Global Cholera Control Programmes, presented to the WHO SAGE (Strategic Advisory Group of Experts) meeting of 27-29 October 2009.

Bik, E.M., Bunschoten, A.E., Gouw, R.D. and Mooi, F.R. (1995). Genesis of the novel epidemic Vibrio cholerae O139 strain: evidence for horizontal transfer of genes involved in polysaccharide synthesis. The EMBO Journal. 14, pp. 209-216.

Bishagratna, K. (1963). An English Translation of the Sushruta Samhita. Chowkhamba Sanskrit Series Office. Varanasi, India. pp. 352-356.

Bitton, G. (2005). Wastewater Microbiology. Third ed. John Wiley and Sons, Inc. Hoboken, New Jersey.

Blackstone, G.M., Nordstrom, J.L., Bowen, M.D., Meyer, R.F., Imbro, P. and DePaola, A. (2007). Use of a real time PCR assay for detection of the $c t x A$ gene of Vibrio cholerae in an environmental survey of Mobile Bay. Journal of Microbiological Methods. 68, pp. 254-259.

Blake, P.A., Rosenberg, M.L., Florencia, J., Costa, J.B., Quintino, L.D.P. and Gangarosa, E.J. (1977). I. Cholera in Portugal, 1974. II. Transmission by bottled mineral water. American Journal of Epidemiology. 105, pp. 344-348.

Blokesh, M. and Schoolnik, G.K. (2007). Serogroup conversion of Vibrio cholerae in aquatic reservoirs. PLoS Pathogens. 3, pp. 0477-0746.

Brayton, P.P., Tamplin, M.L., Huq, A. and Colwell, R.R. (1987). Enumeration of Vibrio cholerae O1 in Bangladesh waters by fluorescent antibody direct viable count. Applied and Environmental Microbiology. 53, pp. 2862-2863.

Brown, M.R.W. and Barker, J. (1999). Unexplored reservoirs of pathogenic bacteria: protozoa and biofilms. Trends in Microbiology. 7, pp. 46-50. 
Brown, R.C. and Taylor, R.K. (1995). Organization of tcp, acf, and toxT genes within a ToxT-dependent operon. Molecular Microbiology. 16, pp. 425-439.

Broza, M. and Halpern, M. (2001). Chironomid egg masses and Vibrio cholerae. Nature. 412, pp. 40.

Cabral, J.P.S. (2010). Water microbiology: bacterial pathogens and water. International Journal of Environmental Research and Public Health. 7, pp. 3657-3703.

Caldini, G., Neri, A., Cresti, S., Boddi, V., Rossolini, G.M. and Lanciotti, E. (1997). High prevalence of Vibrio cholerae nonO1 carrying heat-stable-enterotoxin among Vibrio isolates from a temperate-climate river basin of central Italy. Applied and Environmental Microbiology. 63, pp. 2934-2939.

Carr, R. (2001). Excreta-related infections and the role of sanitation in the control of transmission. Guidelines, Standards and Health: Assessment of Risk and Risk Management for Water-Related Infectious Disease. (Fewtrell, L. and Bartram, J., ed.). WHO.

Carvajal, G.H., Sanchez, J., Ayala, M.E. and Hase, A. (1988). Differences among marine and hospital strains of Vibrio cholerae during Peruvian epidemic. J Gen Appl Microbiol. 144, pp. 27-33.

Cash, R.A., Music, S.I., Libonati, J.P., Craig, J.P., Pierce, N.F. and Hornick, R.B. (1974). Response of man to infection with Vibrio cholerae. II. Protection from illness afforded by previous disease and vaccine. The Journal of Infectious Diseases. 130, pp. 325-333.

CDC (2015). Cholera - Vibrio cholera infection. Diagnosis and detection. How to Diagnose. Rapid Test. Centers for Disease Control and Prevention.

CDC (1991). Cholera associated with imported frozen coconut milk-Maryland, 1991. Morbidity and Mortality Weekly Report. 40, pp. 844-845.

Ceccarelli, D., Spagnoletti, M., Bacciu, D., Cappuccinelli, P. and Colombo, M.M. (2011). New V. cholerae atypical El Tor variant emerged during the 2006 epidemic outbreak in Angola. BMC Microbiology. 11, pp. 130.

Chakraborty, S., Khanam, J., Takeda, Y. and Nair, G.B. (1999). Application of PCR for detection of toxigenic Vibrio cholerae O1 in water samples during an outbreak of cholera. Transactions of the Royal Society of Tropical Medicine and Hygiene. 93, pp. 527-528.

Chen, H., Zheng, Y., Jiang, J.H., Wu, H.L., Shen, G.L. and Yu, R.Q. (2008). An ultrasensitive chemiluminescence biosensor for cholera toxin based on ganglioside-functionalized supported lipid membrane and liposome. Biosensors and Bioelectronics. 24, pp. 684-689.

Chen, W., Zhang, J., Lu, G., Yuan, Z., Wua, Q., Li, J. et al. (2014). Development of an immunochromatographic lateral flow device for rapid diagnosis of Vibrio cholerae 01 serotype Ogawa. Clinical Biochemistry. 47, pp. 448-454.

Clemens, J.D., Sack, D.A., Harris, J.R., Chakraborty, J., Khan, M.R., Huda, S. et al. (1989). ABO blood groups and cholera: new observations on specificity of risk and modification of vaccine efficacy. The Journal of Infectious Diseases. 159, pp. 770-773.

Colwell, R. (2013). Oceans, Climate, and Health: Cholera as a Model of Infectious Diseases in a Changing Environment. Civic Scientist Lecture Series at the James A. Baker III Institute for Public Policy, Houston, TX, March. 7, pp. 2013.

Colwell, R.R. (1996). Global climate and infectious diseases: The cholera paradigm. Science, New Series. 274, pp. 2012-2031.

Colwell, R.R. and Huq, A. (1994). Environmental reservoir of Vibrio cholerae, the causative agent of cholera. Annals of the New York Academy of Sciences. 740, pp. 44-54.

Colwell, R.R., Kaper, J. and Joseph, S.W. (1977). Vibrio cholerae, Vibrio parahaemolyticus and other vibrios: occurrence and distribution in Chesapeake Bay. Science. 198, pp. 394-396. 
Colwell, R.R., Seidler, R.J., Kaper, J., Joseph, S.W., Garges, S., Lockman, H. et al. (1981). Occurrence of Vibrio cholerae serotype $\mathrm{O} 1$ in Maryland and Louisiana estuaries. Applied and Environmental Microbiology. 41, pp. 555-558.

Cox, P., Griffith, M., Angles, M., Deere, D. and Ferguson, C. (2005). Concentrations of pathogens and indicators in animal feces in the Sydney Watershed. Applied and Environmental Microbiology. 10, pp. 5929-5934.

Daniel, R.R. and Lloyd, B. (1980). Microbiological studies on two Oxfam sanitation units operating in Bengali refugee camps. Water Research. 14, pp. 1567-1571.

Daniel, R.R. and Lloyd, B. (1979). Sanitation and disease in Bangladesh urban slums and refugee camps. Progress in Water Technology. 11, pp. 191-200.

Daniels, D.L., Cousens, S.N., Makoae, L.N. and Feachem, R.G. (1990). A case control study of the impact of improved sanitation on diarrhoea morbidity in Lesotho. Bulletin of the World Health Organization. 68, pp. 455-463.

Das, B., Halder, K., Pal, P. and Bhadra, R.K. (2007). Small chromosomal integration site of classical CTX prophage in Mozambique Vibrio cholerae 01 biotype El Tor strain. Archives of Microbiology. 188, pp. 677-683.

Davis, B.M., Lawson, E.H., Sandkvist, M., Ali, A., Sozhamannan, S. and Waldor, M.K. (2000). Convergence of the secretory pathways for cholera toxin and the filamentous phage, CTXU. Science. 288, pp. 333-335.

Davis, B.M. and Waldor, M.K. (2003). Filamentous phages linked to virulence of Vibrio cholerae. Current Opinion in Microbiology. 6, pp. 35-42.

Deen, J.L., von Seidlein, L., Sur, D., Agtini, M., Lucas, M.E., Lopez, A.L. et al. (2008). The high burden of cholera in children: comparison of incidence from endemic areas in Asia and Africa. PLoS Neglected Tropical Diseases. 2(2), pp. e173.

DePaola, A. (1981). Vibrio cholerae in marine foods and environmental waters: a literature review. Journal of Food Science. 46, pp. 66-70.

Dizon, J.J. (1974). Cholera carriers. Cholera. (Barua, D. and Burrows, W., ed.). Saunders WB Co. Philadelphia, PA. pp. 367-379.

Dizon, J.J., Fukumi, H., Barua, D., Valera, J., Jayme, F., Gomez, F. et al. (1967). Studies on cholera carriers. Bulletin of the World Health Organization. 37, pp. 737-743.

Djaouda, M., Gaké, B., Menye, D.E., Togouet, S.H.Z., Nola, M. and Njiné, T. (2013). Survival and growth of Vibrio cholerae, Escherichia coli, and Salmonella spp. in well water used for drinking purposes in Garoua (North Cameroon). International Journal of Bacteriology. 1-7,.

Donitz, W. (1892). Bemerkungen zur Cholerafrage. Zeitschrift für Hygiene. 1, pp. 405.

Downs, T.J., Cifuentes-Garcia, E. and Suffet, I.M. (1999). Risk screening for exposure to groundwater pollution in a wastewater irrigation district of the Mexico City region. Environmental Health Perspectives. 107, pp. 553-561.

Drasar, B.S. and Forrest, B.D. (1996). Cholera and the Ecology of Vibrio cholerae. Chapman and Hall. London, UK. pp. 535.

Duan, J. and Su, Y.C. (2005). Comparison of a chromogenic medium with thiosulfate-citrate-bile salts-sucrose agar for detecting Vibrio parahaemolyticus. Journal of Food Science. 70, pp. M125-M128.

Dumontet, S., Krovacek, K., Baloda, S.B., Grottoli, R., Pasquale, V. and Vanucci, S. (1996). Ecological relationship between Aeromonas and Vibrio spp. and planktonic copepods in the coastal marine environment in Southern Italy. Comparative Immunology, Microbiology and Infectious Diseases. 19, pp. 245-254.

Dungeni, M., Van der Merwe, R.R. and Momba, M.N.B. (2010). Abundance of pathogenic bacteria and viral indicators in chlorinated effluents produced by four wastewater treatment plants in the Gauteng Province, South Africa. Water SA. 36, pp. 607-614. 
du Preez, M., Venter, S.N. and Theron, J. (2003). Detection of viable toxigenic Vibrio cholerae and virulent Shigella spp. in environmental waters by pit-stop seminested polymerase chain reaction assays. Water SA. 29, pp. 177-182.

du Preez, M., Van der Merwe, M.R., Cumbana, A. and le Roux, W. (2010). A survey of Vibrio cholerae O1 and O139 in estuarine waters and sediments of Beira, Mozambique. Water SA. 36, pp. 615-620.

Dutta, D., Chowdhury, G., Pazhani, G.P., Guin, S., Dutta, S., Ghosh, S. et al. (2013). Vibrio cholerae Non-O1, Non-O139 Serogroups and Cholera-like Diarrhea, Kolkata, India. Emerging Infectious Diseases. 19, pp. 464-466.

Eddabra, R., Piemont, Y. and Scheftel, J.M. (2011). Evaluation of a new chromogenic medium, chromID ${ }^{\mathrm{TM}}$ Vibrio, for the isolation and presumptive identification of Vibrio cholerae and Vibrio parahaemolyticus from human clinical specimens. European Journal of Clinical Microbiology and Infectious Diseases. 30, pp. 733-737.

Edwards, K.A. and March, J.C. (2007). GM1-functionalized liposomes in a microtiter plate assay for cholera toxin in Vibrio cholerae culture samples. Analytical Biochemistry. 368, pp. 39-48.

El-Lathy, M.A. (2009). Comparative study between different methods for detection and enumeration of pathogenic bacteria from aquatic environment. Cairo University.

El-Lathy, M.A., El-Taweel, G.E., El-Sonosy, W.M., Samhan, F.A. and Moussa, T.A.A. (2009). Determination of pathogenic bacteria in wastewater using conventional and PCR techniques. Environmental Biotechnology. 5, pp. 73-80.

Epstein, P.R. (1993). Algal blooms in the spread and persistence of cholera. Biosystems. 31, pp. 209-221.

Esrey, S., Gough, J., Rapaport, D., Sawyer, R., Simpson-Hebert, M., Vargas, J. et al. (1998). Ecological sanitation.

EWARS (2017). WHO, Surveillance in response to the cholera outbreak in Yemen.

Farmer, III, J.J., Janda, J.M. and Birkhead, K. (2003). Vibrio. Manual of Clinical Microbiology. 8th ed. (Murray, P.R., Baron, E.J., Jorgensen, J.H., Pfaller, M.A. and Yolken, R.H., ed.). ASM Press. Washington, DC. pp. 706.

Farmer, III, J.J., Janda, J.M., Hickman-Brenner, F.W., Cameron, D.N. and Birkhead, K.M. (2005). Genus Vibrio. The Proteobacteria, Part B, Bergey's Manual of Systematic Bacteriology. 2nd ed. (Brenner, D.J., Krieg, J.T., Staley, J.T. and Garritym, G.M., ed.). Springer-Verlag. New York, NY. pp. 494.

Faruque, A.S.G., Alam, K., Malek, M.A., Khan, M.G.Y., Ahmed, S. and Saha, D. (2007). Emergence of multidrug-resistant strain of Vibrio cholerae $\mathrm{O} 1$ in Bangladesh and reversal of their susceptibility to tetracycline after two years. Journal of Health, Population and Nutrition. 25, pp. 241-243.

Faruque, A.S.G., Mahalanabis, D., Hoque, S.S. and Albert, M.J. (1994). The relationship between ABO blood groups and susceptibility to diarrhea due to Vibrio cholerae 0139. Clinical Infectious Diseases. 18, pp. 827-828.

Faruque, S.M., Albert, M.J. and Mekalanos, J.J. (1998). Epidemiology, genetics and ecology of toxigenic Vibrio cholerae. Microbiology and Molecular Biology Reviews. 62, pp. 1301-1314.

Faruque, S.M., Tam, V.C., Chowdhury, N., Diraphat, P., Dziejman, M., Heidelberg, J.F. et al. (2007). Genomic analysis of the Mozambique strain of Vibrio cholerae 01 reveals the origin of El Tor strains carrying classical CTX prophage. Proceedings of the National Academy of Sciences of the United States of America. 104, pp. 5151-5156.

Feikin, D.R., Tabu, C.W. and Gichuki, J. (2010). Does water hyacinth on east African lakes promote cholera outbreaks?. The American Journal of Tropical Medicine and Hygiene. 83, pp. 370-373.

Feldhusen, F. (2000). The role of seafood in bacterial foodborne diseases. New Microbes New Infections. 2, pp. 1651-1660.

Felsenfeld, O. (1967). The cholera problem. (Green, W.H., ed.). pp. 165.

Fenwick, A. (2006). Waterborne infectious diseases - could they be consigned to history?. Science. 313, pp. 1077-1081. Fernandez, M.A.L., Schomaker, M., Mason, P.R., Fesselet, J.F., Baudot, Y., Boulle, A. et al. (2012). Elevation and cholera: 
an epidemiological spatial analysis of the cholera epidemic in Harare, Zimbabwe, 2008-2009. BMC Public Health. 12, pp. 442.

Finkelstein, R.A. (1996). Vibrio cholerae 01 and 0139, and other pathogenic vibrios,. Medical Microbiology. 4th ed. (Baron, S., ed.).

Flu, P.C. (1921). Investigations of the duration of life of cholera vibriones and typhoid in septic tanks at Batavia. Mededeelingen van den Burgerlijken Geneeskundigen Dienst in Nederlandsch-Indie. 3, pp. 178-187.

Gaudart, J., Rebaudet, S., Barrais, R., Boncy, J., Faucher, B., Piarroux, M. et al. (2013). Spatio-temporal dynamics of cholera during the first year of the epidemic in Haiti. PLOS Neglected Tropical Diseases. 7, pp. 2145.

Gazi, H., Das, K., Mukandavire, Z., Chikaya, C. and Das, P. (2010). A study of cholera model with environmental fluctuations. International Journal of Mathematical Models and Methods in Applied Sciences. 4, pp. 150-155.

Ghosh-Banerjee, J., Senoh, M., Takahashi, T., Hamabata, T., Barman, S., Koley, H. et al. (2010). Cholera toxin production by the El Tor variant of Vibrio cholerae 01 compared to prototype El Tor and classical biotypes. Journal of Clinical Microbiology. 48, pp. 4283-4286.

Ghosh, P., Naha, A., Basak, S., Ghosh, S., Ramamurthy, T., Koley, H. et al. (2014). Haitian Variant tcpA in Vibrio cholerae O1 El Tor strains of Kolkata, India. Journal of Clinical Microbiology. PMID:24371,.

Glass, R.I., Becker, S., Huq, M.J., SIofl, B.J., Khan, M.U., Meraon, M.H. et al. (1982). Endemic cholera in rural Bangladesh, 1966-1980. American Journal of Epidemiology. 116, pp. 959-970.

Glass, R.I. and Black, R.E. (1992). The epidemiology of cholera. Current Topics in Infectious Disease: Cholera. (Barua, D. and Greenough, W.B., ed.). Plenum Medical Book Co. New York, NY. pp. 129-154.

Glass, R.I., Holmgren, J., Haley, C.E., Khan, M.R., Svennerholm, A.M., Stoll, B.J. et al. (1985). Predisposition for cholera of individuals with O blood group. Possible evolutionary significance. American Journal of Epidemiology. 121, pp. 791-796.

Goel, A.K., Tamrakar, A.K., Kamboj, D.V. and Singh, L. (2005). Direct immunofluorescence assay for rapid environmental detection of Vibrio cholerae O1. Folia Microbiologica. 50, pp. 448-452.

Grim, C.J., Tediashvili, M., Whitehouse, C.A., Jaiani, E., Kokashvili, T., Janelidze, N. et al. (2010). Detection of toxigenic Vibrio cholerae $\mathrm{O} 1$ from freshwater environments in the former Soviet Republic of Georgia. Environmental Microbiology Reports. 2, pp. 2-6.

Grimes, D.J., Singleton, F.L., Stemmler, J., Palmer, L.M., Brayton, P. and Colwell, R.R. (1984). Microbiological effects of wastewater effluent discharge into coastal waters of Puerto Rico. Water Research. 18, pp. 613-619.

Gross, R., Schell, B., Molina, M.C.B., Leao, M.A.C. and Strack, U. (1989). The impact of improvement of water supply and sanitation facilities on diarrhoea and intestinal parasites: A Brazilian experience with children in two low-income urban communities. Revista Costarricense de Salud Pública. 23, pp. 214-220.

Gruber, J.S., Ercumen, A. and Colford, J.M. (2014). Coliform bacteria as indicators of diarrheal risk in household drinking water: Systematic review and meta-analysis. PLoS one. 9, pp. e107429.

Gutiérrez-Sarabia, A., Fernandez-Villagómez, G., Martinez-Pereda, P., Rinderknecht-SeiJas, N. and Poggi-Varaldo, H.M. (2004). Slaughterhouse wastewater treatment in a full-scale system with constructed wetlands. Water Research. 76, pp. 334-343.

Halpern, M., Broza, Y.B., Mittler, S., Arakawa, E. and Broza, M. (2004). Chironomid egg masses as a natural reservoir of Vibrio cholerae non-O1 and non-O139 in freshwater habitats. Microbial Ecology. 47, pp. 341-349.

Halpern, M., Gancz, H., Broza, M. and Kashi, Y. (2003). Vibrio cholerae hemagglutinin/protease degrades chironomid egg masses. Applied and Environmental Microbiology. 69, pp. 4200-4204. 
Haque, F., Hossain, M.J., Kundu, S.K., Naser, A.M., Rahman, M. and Luby, S.P. (2013). Cholera outbreaks in urban Bangladesh in 2011. Epidemiology (Sunnyvale, Calif.). 126, doi: 10.4172/2161-1165.1000126.

Harris, J.B., Khan, A.I., LaRocque, R.C., Dorer, D.J., Chowdhury, F., Faruque, A.S.G. et al. (2005). Blood group, immunity, and risk of infection with Vibrio cholerae in an area of endemicity. Infection and Immunity. 73, pp. 7422-7427.

Harris, J.B., LaRocque, R.C., Chowdhury, F., Khan, A.I., Logvinenko, T., Faruque, A.S.G. et al. (2008). Susceptibility to Vibrio cholerae infection in a cohort of household contacts of patients with cholera in Bangladesh. PLOS Neglected Tropical Diseases. 2, pp. e221.

Hartley, M.D., Morris, J.G.J. and Smith, D.L. (2006). Hyperinfectivity: A Critical Element in the Ability of V. cholerae to Cause Epidemics?. PLoS Medicine. 3, pp. e7.

Hasan, N.A., Choia, S.Y., Eppingerc, M., Clarka, P.W., Chena, A., Alame, M. et al. (2012). Genomic diversity of 2010 Haitian cholera outbreak strains. Proceedings of the National Academy of Sciences. pp. E2010-E2017.

Hassanin, M.A., Lotfy, N.L., Megeed, KN.Abdel, Abdel-Gawad, F.K., Taweel, GE.El and Bassem, S.M. (2013). Detection of Vibrio spp. in water, some aquatic insects and fish species in River Nile, Egypt. Global Veterinaria. 10, pp. $253-263$.

Heggelund, J.E., Haugen, E., Lygren, B., Mackenzie, A., Holmner, A., Vasile, F. et al. (2012). Both El Tor and classical cholera toxin bind blood group determinants. Biochemical and Biophysical Research Communications. 418, pp. 731-735.

Heiser, V.G. (1908). Some considerations on the frequent reappearance of cholera in the Philippine Islands, with statistics beginning with the outbreak in 1902 to January 1, 1908. The Philippine Journal of Science. 3, pp. 89.

Hijnen, W.A.M., Beerendonk, E.F. and Medema, G.J. (2006). Inactivation credit of UV radiation for viruses, bacteria and protozoan (oo) cysts in water: A review. Water Research. 40, pp. 3-22.

Hill, V.R., Cohen, N., Kahler, A.K., Jones, J.K., Bopp, C.A., Marano, N. et al. (2011). Toxigenic Vibrio cholerae O1 in water and seafood, Haiti. Emerging Infectious Diseases. 17, pp. 2147-2150.

Hisatsune, K., Kondo, S., Isshiki, Y., Iguchi, T., Y, K. and Shimada, T. (1993). O-antigenic lipopolysaccharide of Vibrio cholerae 0139 Bengal, a new epidemic strain for recent cholera in the Indian subcontinent. Biochemical and Biophysical Research Communications. 196, pp. 1309-1315.

Hochhut, B. and Waldor, M.K. (1999). Site-specific integration of the conjugal Vibrio cholerae SXT element into prfC. Molecular Microbiology. 32, pp. 99-110.

Holmgren, J. and Czerkinsky, C. (2005). Mucosal immunity and vaccines. Nature Medicine. 11, pp. S45-S53.

Holmner, A., Mackenzie, A. and Krengel, U. (2010). Molecular basis of cholera blood-group dependence and implication for a world characterised by climate change. FEBS Letters. 584, pp. 2548-2555.

Howard, J., Lloyd, B. and Webber, D. (1975). Oxfam's Sanitation Unit: The design and testing of a sanitation and sewage treatment unit for disasters and long term use. 2nd ed. Oxfam Technical Paper. Oxfam, UK.

Hughes, J.M., Boyce, J.M., Boyce, J.M., Levine, R.J., Khan, M., Aziz, K.M.A. et al. (1982). Epidemiology of El Tor cholera in rural Bangladesh: Importance of surface water in transmission. Bulletin of the World Health Organization. 60, pp. 395-404.

Huq, A. and Colwell, R.R. (1996). Vibrios in the marine and estuarine environment: tracking of Vibrio cholerae. Ecosystem Health. 2, pp. 198-214.

Huq, A., Sack, R. and Colwell, R.R. (2001). Cholera and global ecosystems. Ecosystem Change and Public Health: A Global Perspective. (Aron, J. and Patz, J., ed.). Johns Hopkins University Press. Baltimore, Maryland. pp. 327-347.

Huq, A., Sack, R.B., Nizam, A., Longini, I.M., Nair, G.B., Ali, A.J. et al. (2005). Critical factors influencing the occurrence of Vibrio cholerae in the environment of Bangladesh. Applied and Environmental Microbiology. 71, pp. 4645-4654. 
Huq, A., Small, E.B., West, P.A., Huq, M.I., Rahman, R. and Colwell, R.R. (1983). Ecological relationships between Vibrio cholerae and planktonic crustacean copepods. Applied and Environmental Microbiology. 45, pp. 275-283.

Igbinosa, E.O., Obi, C.L. and Okoh, A.I. (2009). Occurrence of potentially pathogenic vibrios in the final effluents of a wastewater treatment facility in a rural community of the Eastern Cape Province of South Africa. Research in Microbiology. 160, pp. 531-537.

Islam, M., Hasan, M., Miah, M., Yunus, M., Zaman, K. and Albert, M. (1994). Isolation of Vibrio cholerae O139 synonym Bengal from the aquatic environment in Bangladesh: implications for disease transmission. Applied and Environmental Microbiology. 60, pp. 1684-1686.

Islam, M.S., Drasar, B.S. and Bradley, D.J. (1990). Long-term persistence of toxigenic Vibrio cholerae 01 in the mucilaginous sheath of a blue green alga, Anabaena variabilis. Journal of Tropical Medicine and Hygiene. 93, pp. 133-139.

ISO (2007). Microbiology of food and animal feeding stuffs - horizontal method for the detection of potentially enteropathogenic Vibrio spp. Part-2: Detection of species other than Vibrio parahaemolyticus and Vibrio cholerae.

Isshiki, Y., Kondo, S., Iguchi, T., Sano, Y., Shimada, T. and Hisatsune, K. (1996). An immunochemical study of serological cross-reaction between lipopolysaccharides from Vibrio cholerae O22 and O139. Microbiology. 142, pp. 1499-1504.

Jackson, S. and Beney, C. (2000). Detection of Vibrio cholerae in river water in the vicinity of an informal settlement. WISA 2000 Biennial Conference. Sun City, South Africa.

Jain, V., Dongre, M. and Raychaudhuri, S. (2006). Interaction of Vibrio cholerae O139 with an intestinal parasite, Entamoeba histolytica. Indian Journal of Medical Microbiology. 55, pp. 1755-1756.

Jeffs, A.G., Nichols, P.D., Mooney, B.D., Philips, K.L. and Phleger, C.F. (2004). Identifiying potential prey of the pelagic larvae of the spiny lobster Jasus edwardsii using signature lipids. Comparative Biochemistry and Physiology Part B: Biochemistry and Molecular Biology. 137, pp. 487-507.

Jesudason, M.V., Balaji, V., Mukudan, U. and Thomas, C.J. (2000). Ecological study of Vibrio cholerae in Vellore. Epidemiology and Infection. 124, pp. 201-206.

Johnson, C., Flowers, A., Noriea, N., Zimmerman, A., Bowers, J., DePaola, A. et al. (2010). Relationships between environmental factors and pathogenic Vibrios in the Northern Gulf of Mexico. Applied and Environmental Microbiology. 76, pp. 7076-7084.

Johnson, C.N., Bowers, J.C., Griffitt, K.J., Molina, V., Clostio, R.W., Pei, S. et al. (2012). Ecology of Vibrio parahaemolyticus and Vibrio vulnificus in the coastal and estuarine waters of Louisiana, Maryland, Mississippi, and Washington (United States). Applied and Environmental Microbiology. 78, pp. 7249-7257.

Joseph, S. and Bhat, K.G. (2000). Effect of iron on the survival of Vibrio cholerae in water. The Indian Journal of Medical Research. 111, pp. 115-117.

Jubair, M., Morris, Jr, J.G. and Ali, A. (2012). Survival of Vibrio cholerae in nutrient- poor environments is associated with a novel "persister" phenotype. PLoS one. 7, pp. e45187. doi: 10.1371/journal.pone.0045187.

Kaper, J.B., Morris, J.G. and Levin, M.M. (1995). Cholera. Clinical Microbiology Reviews. 8, pp. 48-86.

Karaolis, A.K.R., Lan, R., Kaper, J.B. and Reeves, P.R. (2001). Comparison of Vibrio cholerae pathogenicity islands in sixth and seventh pandemic strains. Infection and Immunity. 69, pp. 1947-1952.

Karaolis, D.K., Somara, S., Maneval, Jr, D.R., Johnson, J.A. and Kaper, J.B.A. (1999). A bacteriophage encoding a pathogenicity island, a type-IV pilus and a phage receptor in cholera bacteria. Nature. 399, pp. 375-379.

Karlsson, E.K., Harris, J.B., Tabrizi, S., Rahman, A., Shlyakhter, I., Patterson, N. et al. (2013). Natural selection in a Bangladeshi population from the cholera-endemic Ganges River Delta. Science Translational Medicine. 5, pp. 186-192. 
Karunasagar, I., Nayak, B.B. and Karunasagar, I. (1997). Rapid detection of Vibrio parahaemolyticus from fish by polymerase chain reaction (PCR). Diseases in Asian Aquaculture III. (Flegel, T.W. and MacRae, I.H., ed.). Asian Fisheries Society. Manila. pp. 119-122.

Kay, B.A., Bopp, C.A. and Wells, J.G. (1994). Isolation and identification of Vibrio cholerae 01 from fecal specimens. Vibrio cholerae and Cholera: Molecular to Global Perspectives. (Wachsmuth, I.K., Blake, P.A. and Olsvik, O., ed.). American Society for Microbiology Press. Washington, DC. pp. 465.

Kaysner, C.A., Abeyta, J.C., Wekell, M.M., DePaola, J.A., Stott, R.F. and Leitch, J.M. (1987). Incidence of Vibrio cholerae from estuaries of the United States west coast. Applied and Environmental Microbiology. 53, pp. 1344-1348.

Kaysner, C.A. and Hill, W.E. (1994). Toxigenic Vibrio cholerae 01 in food and water. Vibrio cholerae and Cholera: Molecular to Global Perspectives. (Wachsmuth, K.I., Blake, P.A. and Olsvik, O., ed.). American Society for Microbiology. Washington, DC. pp. 27-39.

Keddy, K.H., Sooka, A., Parsons, M.B., Njanpop-Lafourcade, B.M., Fitchet, K. and Smith, A.M. (2013). Diagnosis of Vibrio cholerae 01 Infection in Africa. The Journal of Infectious Diseases. 208, pp. S23-S31.

Keen, M.F. and Bujalski, L. (1992). The diagnosis and treatment of cholera. Nurse practitioner. 17, pp. 53-56.

Keshav, V., Potgieter, N. and Bernard, T.G. (2010). Detection of Vibrio cholerae O1 in animal stools collected in rural areas of the Limpopo Province. Water SA. 36, pp. 167-171.

Kiiyukia, C., Nakajima, A., Nakai, T., Muroga, K., Kawakami, H. and Hashimoto, H. (1992). Vibrio cholerae non-O1 isolated from Ayu fish (Plecoglossus altivelis) in Japan. Applied and Environmental Microbiology. 58, pp. 3078-3082.

Knirel, Y.A., Widmalm, G., Senchenkova, S.N., Jansson, P.E. and Weintraub, A. (1997). Structural studies on the short-chain lipopolysaccharide of Vibrio cholerae 0139 Bengal. European Journal of Biochemistry. 247, pp. 402-410.

Koelle, K., Pascual, M. and Yunus, M. (2005). Pathogen adaptation to seasonal forcing and climate change. Proceedings of the Royal Society of London. Series B: Biological Sciences. 272, pp. 971-977.

Koelle, K., Rodó, X., Pascual, M., Yunus, M. and Mostafa, G. (2005). Refractory periods and climate forcing in cholera dynamics. Nature. 436, pp. 696-700.

Kolvin, J.L. and Roberts, D. (1982). Studies on the growth of Vibrio cholerae biotype El Tor and biotype classical in foods. Epidemiology and Infection. 89, pp. 243-252.

Kong, R.Y.C., Lee, S.K.Y., Law, T.W.F., Law, S.H.W. and Wu, R.S.S. (2002). Rapid detection of six types of bacterial pathogens in marine waters by multiplex PCR. Water Research. 36, pp. 2802-2812.

Kott, Y. and Betzer, N. (1972). The fate of Vibrio cholerae (El Tor) in oxidation pond effluents. Israel Journal of Medical Sciences. 8, pp. 1912-1916.

Kuberski, T., Flood, T. and Tera, T. (1979). Cholera in the Gilbert Island. I. Epidemiological features. The American Journal of Tropical Medicine and Hygiene. 28, pp. 677-684.

Kwon, J.D. (2010). Occurrence of non-O1/non-O139 Vibrio cholerae and Aeromonas spp. in Arizona recreational waters. University of Arizona.

Lacey, S.W. (1995). Cholera: Calamitous past, ominous future. Clinical Infectious Diseases. 20, pp. 1409-1419.

Legros, D., McCormick, M., Mugero, C., Skinnider, M., Bek'Obita, D.D. and Okware, S.I. (2000). Epidemiology of cholera outbreak in Kampala, Uganda. East African Medical Journal. 77(7), pp. 347-349.

Levine, M.M., Black, R.E., Clements, M.L., Cisneros, L., Nalin, D.R. and Young, C.R. (1981). Duration of infection-derived immunity to cholera. The Journal of Infectious Diseases. 143, pp. 818-820. 
Lindenbaum, J., Greenough, W.B. and Islam, M.R. (1967). Antibiotic therapy of cholera. Bulletin of the World Health Organization. 36, pp. 871-883.

Lipp, E.K., Rivera, I.N.G., Gil, A., Espeland, E.M., Choopun, N., Louis, V.R. et al. (2003). Direct detection of Vibrio cholerae and ctxA in Peruvian coastal water and plankton by PCR. Applied and Environmental Microbiology. 69, pp. 3676-3680.

Louis, V.R., Russek-Cohen, E., Choopun, N., Rivera, I.N., Gangle, B., Jiang, S.C. et al. (2003). Predictability of Vibrio cholerae in Chesapeake Bay. Applied and Environmental Microbiology. 69, pp. 2773-2785.

Lutz, C., Erken, M., Noorian, P., Sun, S. and McDougald, D. (2013). Environmental reservoirs and mechanisms of persistence of Vibrio cholerae. Frontiers in Microbiology. 4, pp. 1-15.

Madoroba, E. and Momba, M.N.B. (2010). Prevalence of Vibrio cholerae in rivers of Mpumalanga province, South Africa as revealed by polyphasic characterization. African Journal of Biotechnology. 9, pp. 7295-7301.

Maheshwari, M., Nelapati, K. and Kiranmayi, B. (2011). Vibrio cholerae - a review. Veterinary World. 4, pp. 423-428.

Malley, J.P. (2000). Ultraviolet disinfection. Control of Microbes in Drinking Water. (Lingireddy, S., ed.). American Society of Civil Engineering. Reston, VA.

Mandal, S., Mandal, M.D. and Pal, N.K. (2011). Cholera: a great global concern. Asian Pacific Journal of Tropical Medicine. 4, pp. 573-580.

Mariita, M.R. and Okemo, O.P. (2009). Usefulness of faecal Streps as indicator of presence of Salmonella sp. and Vibrio cholerae in sewage effluents. The Malaysian Journal of Microbiology. 5, pp. 19-24.

Marin, M.A., Thompson, C.C., Freitas, F.S., Fonseca, E.L. and Aboderin, A.O. (2013). Cholera Outbreaks in Nigeria Are Associated with Multidrug Resistant Atypical El Tor and Non-O1/Non-O139 Vibrio cholerae. PLOS Neglected Tropical Diseases. 7, pp. e2409. doi: 10.1371/journal.pntd.0002049.

Matte, G.R., Matte, M.H., Sato, M.I.Z., Sanchez, P.S., Rivera, I.G. and Martins, M.T. (1994). Potentially pathogenic vibrios associated with mussels from a tropical region on the Atlantic coast of Brazil. Journal of Applied Bacteriology. 77, pp. 281-287.

Mekalanos, J.J., Rubin, E.J. and Waldor, M.K. (1997). Cholera: molecular basis for emergence and pathogenesis. FEMS Immunology and Medical Microbiology. 18, pp. 241-248.

Mendes, C.L., Abath, F.G.C. and Leal, N.C. (2008). Development of a multiplex single-tube nested PCR (MSTNPCR) assay for Vibrio cholerae 01 detection. Journal of Microbiological Methods. 72, pp. 191-196.

Merson, M.H., Martin, W.T., Craig, J.P., Morris, G.K., Blake, P.A., Craun, G.F. et al. (1977). Gangarosa EJ. 1977. Cholera on Guam, 1974: epidemiologic findings and isolation of non-toxinogenic strains. American Journal of Epidemiology. 105, pp. 349-361.

Momba, M.N.B., Osode, A.N. and Sibewu, M. (2006). The impact of inadequate wastewater treatment on the receiving water bodies - case study: Buffalo City and Nkonkobe Municipalities of the Eastern Cape Province. Water SA. 32, pp. 687-692.

Momtaz, H., Dehkordi, F.S., Rahimi, E. and Asgarifar, A. (2013). Detection of Escherichia coli, Salmonella species, and Vibrio cholerae in tap water and bottled drinking water in Isfahan, Iran. BMC Public Health. 13, pp. 556-262.

Mosley, W.H., Ahmad, S., Benenson, A.S. and Ahmed, A. (1968). The relationship of vibriocidal antibody titre to susceptibility to cholera in family contacts of cholera patients. Bull World Health Organ. 38, pp. 777-785.

Mosley, W.H., Aziz, K.M., Rahman, AS.Mizanur, Chowdhury, AK.Alauddin, Ahmed, A. and Fahimuddin, M. (1972). Report of the 1966-67 cholera vaccine trial in rural East Pakistan. Bulletin of the World Health Organization. 47, pp. 229-238.

Mossel, D.A.A., Struijk, C.B. and Jansen, J.T. (1992). Control of the transmission of Vibrio cholerae and other 
enteropathogens by foods originating from endemic areas in South America and elsewhere as a model situation. International Journal of Food Microbiology. 15, pp. 1-11.

Mukhopadhyay, A.K., Takeda, Y. and G Nair, B. (2014). Cholera Outbreaks in the El Tor Biotype Era and the Impact of the New El Tor Variants. Current Topics in Microbiology and Immunology. 379, pp. 17-47. doi: 10.1007/82_2014_363.

Na-Ubol, M., Srimanote, P., Chongsa-Nguan, M., Indrawattana, N., Sookrung, N., Tapchaisri, P. et al. (2011). Hybrid\&amp;El Tor variant biotypes of Vibrio cholerae O1 in Thailand. The Indian Journal of Medical Research. 133, pp. 387-394.

Naha, A., Chowdhury, G., Ghosh-Banerjee, J., Senoh, M., Takahashi, T., Ley, B. et al. (2013). Molecular characterization of high-level-cholera-toxin-producing El Tor variant Vibrio cholerae strains in the Zanzibar Archipelago of Tanzania. Journal of Clinical Microbiology. 51, pp. 1040-1045.

Naha, A., Pazhani, G.P., Ganguly, M., Ghosh, S., Ramamurthy, T., Nandy, R.K. et al. (2012). Development and evaluation of a PCR assay for tracking the emergence and dissemination of Haitian variant ctxB in Vibrio cholerae 01 strains isolated from Kolkata, India. Journal of Clinical Microbiology. 50, pp. 1733-1736.

Nair, G.B., Faruque, S.M., Bhuiyan, N.A., Kamruzzaman, M., Siddique, A.K. and Sack, D.A. (2002). New variants of Vibrio cholerae 01 biotype El Tor with attributes of the classical biotype from hospitalized patients with acute diarrhea in Bangladesh. Journal of Clinical Microbiology. 40, pp. 3296-3299.

Nair, G.B., Misra, S., Bhadra, R.K. and Pal, S.C. (1987). Evaluation of the multitest medium for rapid presumptive identification of Vibrio cholerae from environmental sources. Applied and Environmental Microbiology. 53, pp. 1203-1205.

Nair, G.B., Qadri, F., Holmgren, J., Svennerholm, A.M., Safa, A., Bhuiyan, N.A. et al. (2006). Cholera Due to Altered El Tor Strains of Vibrio cholerae O1 in Bangladesh. Journal of Clinical Microbiology. 44, pp. 4211-4213.

Nato, F., Boutonnier, A., Rajerison, M., Grosjean, P., Dartevelle, S., Guénolé, A. et al. (2003). One-step immunochromatographic dipstick tests for rapid detection of Vibrio cholerae $\mathrm{O} 1$ and 0139 in stool samples. Clinical and Diagnostic Laboratory Immunology. 10, pp. 476-478.

Nelson, E.J., Harris, J.B., Morris, J.J.G.Glenn, Calderwood, S.B. and Camilli, A. (2009). Cholera transmission: the host, pathogen and bacteriophage dynamic. Nature Reviews Microbiology. 7, pp. 693-702.

Nevondo, T.S. and Cloete, T.E. (2001). The global cholera pandemic.

Ngari, J., Kotuk, K. and Okemo, P. (2011). Potential threat to wildlife posed by enteric pathogens from Nakuru sewage treatment plant. African Journal of Health Sciences. 18, pp. 85-95.

Nguyen, B.M., Lee, J.H., Cuong, N.T., Choi, S.Y., Hien, N.T., Anh, D.D. et al. (2009). Cholera outbreaks caused by an altered Vibrio cholerae O1 El Tor biotype strain producing classical cholera toxin B in Vietnam in 2007 to 2008. Journal of Clinical Microbiology. 47, pp. 1568-1571.

Nongogo, V. and Okoh, A.I. (2014). Occurrence of Vibrio pathotypes in the final effluents of five wastewater treatment plants in Amathole and Chris Hani District Municipalities in South Africa. International Journal of Environmental Research and Public Health. 11, pp. 7755-7766.

O'Connor, K.A., Cartwright, E., Loharikar, A., Routh, J., Gaines, J., Fouché, M.D. et al. (2011). Risk factors early in the 2010 cholera epidemic, Haiti. Emerging Infectious Diseases. 17, pp. 2136-2138.

Oladele, D.A., Oyedeji, K.S., Niemogha, M.T., Nwaokorie, F., Bamidele, M., Musa, A.Z. et al. (2012). An assessment of the emergency response among health workers involved in the 2010 cholera outbreak in northern Nigeria. Journal of Infection and Public Health. 5(5), pp. 346-353.

World Health Organization, WHO (2000). The Interaction between Assessors and Managers of Microbiological Hazards in Food. WHO Expert Consultation. Kiel, Germany. pp. 21-23. 
Ouseph, P.P., Prasanthan, V., Abhilash, P.P. and Udayakumar, P. (2009). Occurrence and distribution of some bacteria along the southern coast of Kerala. Indian Journal of Marine Sciences. 38, pp. 97-103.

Pandit, C.G. and Hora, S.L. (1951). The probable role of the hilsa fish, Hilsa ilisa (Ham) in maintaining cholera endemicity in India. Indian J Med Sci. 15, pp. 343-356.

Pascual, M., Koelle, K. and Dobson, A.P. (2006). Hyperinfectivity in cholera: a new mechanism for an old epidemiological model. PLoS Medicine. 3, pp. e280.

Patel, M., Isaacson, M. and Koornhof, H.J. (2004). Survival of Vibrio cholerae in industrially polluted water, with particular reference to iron concentrations. Water SA. 30, pp. 65-70.

Pathak, S.P., Gantam, A.R., Ranteke, P.W. and Bhattacherjee, J.W. (1993). Incidence of pathogenic Vibrio cholerae non-O1 in sewage contaminated ground water. Indian J Microbiol. 33, pp. 235-239.

Payment, P., Siemiatycki, J., Richardson, L., Renaud, G., Franco, E. and Prévost, M. (1997). A prospective epidemiological study of gastrointestinal health effects due to the consumption of drinking water. International Journal of Environmental Health Research. 7, pp. 5-31.

Paz, S. and Broza, M. (2007). Wind direction and its linkage with Vibrio cholerae dissemination. Environ Health Perspect. 115, pp. 195-200.

Pesigan, T.P. (1965). Studies on the viability of El Tor vibrios in food stuffs, fomites, and in waters. Proceedings of the Vibrio cholera Research Symposium. pp. 317-332.

Phillips, R.A. (1964). Water and electrolyte losses in cholera. Federation Proceedings. Federation of American Societies for Experimental Biology. 23, pp. 705-712.

Plesnik, V. and Prochazkova, E. (2006). Vibrio cholerae 01 in a fish aquarium. Epidemiologie, Mikrobiologie, Imunologie: Casopis Spolecnosti pro Epidemiologii a Mikrobiologii Ceske Lekarske Spolecnosti JE Purkyne. 55, pp. 30-31.

Pollitzer, R. (1959). Cholera. Monograph Series 43. World Health Organization. Geneva, Switzerland.

Powell, J.L. (1999). Vibrio species. Clinics in Laboratory Medicine. 19, pp. 537-552.

Pruzzo, C., Tarsi, R., Lleò, M.M., Signoretto, C., Zampini, M., Pane, L. et al. (2003). Persistence of adhesive properties in Vibrio cholerae after long term exposure to sea water. Environmental microbiology. 5, pp. 850-858.

Qadri, F., Chowdhury, M.I., Faruque, S.M., A-Salam, M., Ahmed, T., Begum, Y.A. et al. (2005). Randomized, controlled study of the safety and immunogenicity of Peru-15, a live attenuated oral vaccine candidate for cholera, in adult volunteers in Bangladesh. Journal of Infectious Diseases. 192, pp. 573-579.

Rabbani, G.H. and Greenough, W.B. (1999). Food as a vehicle of transmission of cholera. Journal of Diarrhoeal Diseases Research. 17, pp. 1-9.

Rajkowski, K.T., Rice, E.W., Huynh, B. and Patsy, J. (1996). Growth of Salmonella spp. and Vibrio cholerae in reconditioned wastewater. Journal of Food Protection. 59, pp. 577-581.

Ramakrishna, B.S., Kang, G., Rajan, D.P., M, M. and Mathan, V.I. (1996). Isolation of Vibrio cholerae 0 I39 from the drinking water supply during an epidemic of cholera. Tropical Medicine and International Health. 1, pp. 854-858.

Rashid, A., Haley, B.J., Rajabov, M., Ahmadova, A., Gurbanov, S., Colwell, R. et al. (2013). Detection of Vibrio cholerae in environmental waters including drinking water reservoirs of Azerbaijan. Environmental Microbiology Reports. 5, pp. 30-38.

Rask, C., Fredriksson, M., Lindblad, M., Czerkinsky, C. and Holmgren, J. (2000). Mucosal and systemic antibody responses after peroral or intranasal immunization: effects of conjugation to enterotoxin B subunits and/or of co-administration with free toxin as adjuvant. APMIS. 108, pp. 178-186. 
Raychoudhuri, A., Patra, T., Ghosh, K., Ramamurthy, T., Nandy, R.K., Takeda, Y. et al. (2009). Classical ctxB in Vibrio cholerae 01, Kolkata, India. Emerging Infectious Diseases. 15, pp. 131-132.

Reidl, J. and Kiose, K.E. (2002). Vibrio cholerae and cholera: out of the water and into the host. FEMS Microbiology Reviews. 26, pp. 125-139.

Reilly, P.J.A. and Twiddy, D.R. (1992). Salmonella and Vibrio cholerae in brackish water cultured tropical prawns. International Journal of Food Microbiology. 16, pp. 293-301.

Reissbrodt, R., Rienaecker, I., Romanova, J.M., Freestone, P.P.E., Haigh, R.D., Lyte, M. et al. (2003). Resuscitation of Salmonella enterica serovar Typhimurium and enterohemorrhagic Escherichia coli from the viable but nonculturable state by heat-stable enterobacterial autoinducer. Applied and Environmental Microbiology. 68, pp. 4788.

Rice, E.W., Johnson, C.H., Clark, R.M., Fox, K.R., Reasoner, D.J., Dunnigan, M.E. et al. (1993). Vibrio cholerae 01 can assume a 'rugose' survival form that resists killing by chlorine, yet retains virulence. International Journal of Environmental Health Research. 3, pp. 89-98.

Richards, G.P., Watson, M.A. and Parveen, S. (2005). Development of a simple and rapid fluorogenic procedure for the identification of Vibrionaceae family members. Journal of Applied and Environmental Microbiology. 71, pp. 3524-3527.

Ries, A.A., Vugia, D.J., Beingolea, L., Palacios, A.M., Vasquez, E., Wells, J.G. et al. (1992). Cholera in Piura, Peru: a modern urban epidemic. The Journal of Infectious Diseases. 166, pp. 1429-1433.

Rivera, I.G., Chowdhury, M.A.R., Huq, A., Jacobs, D., Martins, M.T. and Colwell, R.R. (1995). Enterobacterial repetitive intergenic consensus sequences and the PCR to generate fingerprints of genomic DNAs from Vibrio cholerae 01, 0139, and non-O1 strains. Applied and Environmental Microbiology. 61, pp. 2898-2904.

Rivera, I.N.G., Chun, J., Huq, A., Sack, R.B. and Colwell, R.R. (2001). Genotypes Associated with Virulence in Environmental Isolates of Vibrio cholerae. Applied and Environmental Microbiology. 67, pp. 2421-2429.

Rose, J., Haas, C. and Gerba, C. (1995). Microbiological Monitoring, Pathogen Removal Assessment and Public. Health Risks Associated with Reclaimed Water. Briefing paper prepared for NSW Recycled Water Committee.

Ruiz-Moreno, D., Pascual, M., Emch, M. and Yunus, M. (2010). Spatial clustering in the spatio-temporal dynamics of endemic cholera. BMC Infectious Diseases. 10, pp. 51.

Sack, D.A., Sack, R.B., Nair, G.B. and Siddique, A.K. (2004). Cholera. Lancet. 363, pp. 223-233.

Sack, R.B., Siddique, A.K., Longini, Jr, I.M., Nizam, A., Yunus, M., Islam, M.S. et al. (2003). A 4-year study of the epidemiology of Vibrio cholerae in four rural areas of Bangladesh. The Journal of Infectious Diseases. 187, pp. 96-101.

Safa, A., Nair, G.B. and Kong, R.Y. (2010). Evolution of new variants of Vibrio cholerae O1. Trends in Microbiology. 18, pp. 46-54.

Samie, A., Obi, C.L., Igumbor, J.O. and Momba, M.N.B. (2009). Focus on 14 sewage treatment plants in the Mpumalanga Province, South Africa in order to gauge the efficiency of wastewater treatment. The African Journal of Biotechnology. 8, pp. 3276-3285.

Sandström, G., Saeed, A. and Abd, H. (2010). Acanthamoeba polyphaga is a possible host for Vibrio cholerae in aquatic environments. Experimental Parasitology. 126, pp. 65-68.

Schürmann, D., Ebert, N., Kampf, N., Baumann, B., Frei, U. and Suttorp, N. (2002). Domestic cholera in Germany associated with fresh fish imported from Nigeria. European Journal of Clinical Microbiology and Infectious Diseases. 21(11), pp. 827-828.

Scott, D.L., Zhang, R.-.G. and Westbrook, E.M. (1996). The cholera family of enterotoxins. Protein Toxin Structure. (Parker, M.W., ed.). R.G. Landes Co. Austin, TX. pp. 123-146. 
Sears, C.L. and Kaper, J.B. (1996). Enteric bacterial toxins: Mechanisms of action and linkage to intestinal secretion. Microbiological Reviews. 60, pp. 167-215.

Seas, C. and Gotuzzo, E. (2009). Vibrio cholerae. Principles and Practice of Infectious Diseases. (Mandell, G.L., Bennett, J.E. and Dolin, R., ed.). Elsevier Health Sciences. Philadelphia, PA. pp. 2777-2791.

Senderovich, Y., Izhaki, I. and Halpern, M. (2010). Fish as reservoirs and vectors of Vibrio cholerae. PLoS one. 5, pp. e8607.

Shapiro, R.L., Otieno, M.R., Adcock, P.M., Phillips-Howard, P.A., Hawley, W.A., Kumar, L. et al. (1999). Transmission of epidemic Vibrio cholerae $\mathrm{O} 1$ in rural western Kenya associated with drinking water from Lake Victoria: an environmental reservoir for cholera?. American Journal of Tropical Medicine and Hygiene. 60(2), pp. 271-276.

Shar, A. (2010). Isolation and identification of pathogenic bacteria from drinking water of Khairpur, Sukkur and Rohri. Shah Abdul Latif University.

Shears, P. (1994). Cholera. Annals of Tropical Medicine and Parasitology. 88, pp. 109-122.

Shimada, T., Arakawa, E., Itoh, K., Okitsu, T.T., Matsushima, A., Asai, Y. et al. (1994). Extended serotyping scheme for Vibrio cholerae. Current Microbiology. 28, pp. 175-178.

Shin, S., Desai, S.N., Sah, B.K. and Clemens, J.D. (2011). Oral vaccines against cholera. Clinical Infectious Diseases. 52, pp. 1343-1349.

Shukla, B.N., Singh, D.V. and Sanyal, S.C. (1995). Attachment of non culturable toxigenic Vibrio cholerae O1 and non-O1, and Aeromonas spp. to aquatic arthropod Gerris spinolae and plants in river Ganga, Varanasi. FEMS Immunology and Medical Microbiology. 12, pp. 113-120.

Shuval, H. (1991). Health guidelines and standards for wastewater reuse in agriculture: historical perspectives. Water Science and Technology. 23, pp. 2073-2080.

Shuval, H.I., Adin, A., Fattal, B., Raawitz, E. and Yekutiel, P. (1986). Wastewater irrigation in developing countries. Health effects and sanitation solutions, World Bank Technical Paper 51, World Bank, Washington DC, USA.

Siddique, A.K., Salam, A., Islam, M.S., Akram, K., Majumdar, R.N., Zaman, K. et al. (1995). Why treatment centres failed to prevent cholera deaths among Rwandan refugees in Goma, Zaire. Lancet. 345, pp. 359-361.

Siddique, A.K., Zaman, K., Baqui, A.H., Akram, K., Mutsuddy, P., Eusuf, A. et al. (1992). Cholera epidemics in Bangladesh: 1985-1991. Journal of Diarrhoeal Diseases Research. 10(2), pp. 79-86.

Singleton, F.L., Attwell, R.W., Jangi, M.S. and Colwell, R.R. (1982). Influence of salinity and organic nutrient concentration on survival and growth of Vibrio cholerae in aquatic microcosms. Applied and Environmental Microbiology. 43, pp. 1080-1085.

Smeets, P., Rietveld, L., Hijnen, W., Medema, G. and Stenström, T.A. (2006). Efficacy of water treatment processes. Microbiological risk assessment: a scientific basis for managing drinking water safety from source to tap. MicroRisk Final Report. pp. 70.

Son, M.S., Megli, C.J., Kovacikova, G., Qadri, F. and Taylor, R.K. (2011). Characterization of Vibrio cholerae O1 El Tor biotype variant clinical isolates from Bangladesh and Haiti, including a molecular genetic analysis of virulence genes. Journal of Clinical Microbiology. pp. 3739-3749.

Speck, R.S. (1993). Cholera. The Cambridge World History of Human Disease. (Kiple, K.F., ed.). Cambridge University Press. Cambridge, UK. pp. 642-649.

Spira, W.M., Huo, A., Ahmed, O. and Saeed, Y.A. (1981). Uptake of Vibrio cholerae biotype El Tor from contaminated water by water hyacinth (Eichhornia crassipes). Applied and Environmental Microbiology. 42, pp. 550-553. 
Stabili, L. and Cavallo, R.A. (2004). Biodeversity of culturable heterotrophic bacteria in the southern Adriatic Sea Italian Coastal waters. Scientia Marina. 68, pp. 31-41.

Sulaiman, I.M., Jiang, J., Singh, A. and Xiao, L. (2004). Distribution of Giardia duodenalis genotypes and subgenotypes in raw urban wastewater in Milwaukee, Wisconsin. Applied and Environmental Microbiology. 70, pp. 3776-3780.

Swerdlow, D.L., Mintz, E.D., Rodirguez, M., Tejada, M., Ocampo, C., Espejo, L. et al. (1992). Waterborne transmission of epidemic cholera in Trujillo, Peru: lessons for a continent at risk. Lancet. 340, pp. 28-32.

Swerdlow, D.L., Mintz, E.D., Rodriguez, M., Tejada, E., Ocampo, C., Espejo, L. et al. (1994). Severe life-threatening cholera associated with blood group $\mathrm{O}$ in Peru: implications for the Latin American epidemic. The Journal of Infectious Diseases. 170, pp. 468-472.

Tacket, C.O., Losonsky, G., Nataro, J.P., Wasserman, S.S., Cryz, S.J., Edelman, R. et al. (1995). Extension of the volunteer challenge model to study South American cholera in a population of volunteers predominantly with blood group antigen $\mathrm{O}$. Transactions of the Royal Society of Tropical Medicine and Hygiene. 89, pp. 75-77.

Talkington, D., Bopp, C., Tarr, C., Parsons, M.B., Dahourou, G., Freeman, G. et al. (2011). Characterization of toxigenic Vibrio cholerae from Haiti, 2010-2011. Emerging Infectious Diseases. 17, pp. 2122-2129.

Tamplin, M.L. and Parodi, C.C. (1991). Environmental spread of Vibrio cholerae in Peru. Lancet. 338, pp. 1216-1217.

Tarr, C.L., Patel, J.S., Puhr, N.D., Sowers, E.G., Bopp, C.A. and Strockbine, N.A. (2007). Identification of Vibrio isolates by a multiplex PCR assay and rpoB sequence determination. Journal of Clinical Microbiology. 46, pp. 134-140.

Tauxe, R.V. and Blake, P.A. (1992). Epidemic cholera in Latin America. The Journal of the American Medical Association. 267, pp. 1388-1390.

Tebbs, R.S., Brzoska, P.M., Furtado, M.R. and Petrauskene, O.V. (2011). Design and validation of a novel multiplex realtime PCR assay for Vibrio pathogen detection. Journal of Food Protection. 74, pp. 939-948.

Teklehaimanot, G.Z., Genthe, B., Kamika, I. and Momba, M.N.B. (2015). Prevalence of enteropathogenic bacteria in treated effluents and receiving water bodies and their potential health risks. The Science of the Total Environment. 518-519, pp. 441-9. doi: 10.1016/j.scitotenv.2015.03.019.

Teklehaimanot, G.Z., Coetzee, M.A.A. and Momba, M.N.B. (2014). Faecal pollution loads in the wastewater effluents and receiving water bodies: a potential threat to the health of Sedibeng and Soshanguve communities, South Africa. Environmental Science and Pollution Research. 21, pp. 1-15.

Teklehaimanot, G.Z., Genthe, B., Kamika, I. and Momba, M.N.B. (2015). Prevalence of enteropathogenic bacteria in treated effluents and receiving water bodies and their potential health risks. Science of the Total Environment. 518-519, pp. 441-449.

Thompson, J., Porras, I.T., Tumwine, J.K., Mujwahuzi, M.R., Katui-Katua, M., Johnstone, N. et al. (2001). Drawer of water II: 30 years of change in domestic water use and environmental health in East Africa. London: IIED.

Thom, S., Warhurst, D. and Drasar, B.S. (1992). Association of Vibrio cholerae with fresh water amoebae. Journal of Medical Microbiology. 36, pp. 303-306.

Toze, S. (1997). Microbial Pathogens in Wastewater. Literature review for urban water systems multi-divisional research program. CSIRO Land and Water Technical Report No 1/97.

Tran, H.D., Alam, M., Trung, N.V., Kinh, N.V., Nguyen, H.H., Pham, V.C. et al. (2012). Multi-drug resistant Vibrio cholerae O1 variant El. Tor isolated in northern Vietnam between 2007 and 2010. Journal of Medical Microbiology. 61, pp. 431-437.

Traoré, O., Martikainen, O., Siitonen, A., Traoré, A.S., Barro, N. and Haukka, K. (2014). Occurrence of Vibrio cholerae in fish and water from a reservoir and a neighboring channel in Ouagadougou, Burkina Faso. Journal of Infection in Developing Countries. 8, pp. 1334-1338. 
Uddin, M.A., Ullah, M.W. and Noor, R. (2012). Prevalence of Vibrio cholerae in human, poultry, animal excreta and compost samples. Stanford Journal of Microbiology. 2, pp. 38-41.

UN's Central Emergency Response Fund (2016). Hurricane Matthew: Haiti battles cholera outbreak. NEWS/Hurricane.

UNESCO (2012). Managing water under uncertainty and risk. The United Nations World Water Development Report 4. United Nations Educational, Scientific and Cultural Organization. Paris, France.

UNICEF (2017). Cholera Outbreaks in Central and West Africa : 2017 Regional Update - Week 26. EU. UK.

UNICEF (2016). WCAR Epidemiological Updates. The United Nations Children's Fund. New York, NY.

USEPA (2003). Ultraviolet Disinfection Guidance Manual, draft. EPA Office of Ground Water and Drinking Water, United States Environmental Protection Agency (US EPA). Washington, DC.

USEPA (1999). Water Efficiency Technology Fact Sheet: Composting Toilets. September 1999. U.S. Environment Protection Agency.

USEPA (1992). Guidelines for Water Reuse. United States Environmental Protection Authority (1992). EPA/625/R-92/004.

Valdespino, J.L. and García-García, L. (2011). Cholera: Environmental risk factors. Encyclopedia of Environmental Health. pp. 641-649.

Valeru, S., Wai, S., Saeed, A., Sandström, G. and Abd, H. (2012). ToxRof Vibrio cholerae affects biofilm, rugosity and survival with Acanthamoeba castellanii. BMC Research Notes. 5, pp. 33.

Verma, P.R.G., Iyer, T.S.G., Joseph, M.A. and Zacharia, S. (1989). Studies on the incidence of Vibrio cholerae in fishery product. Journal of Food Science and Technology. 26, pp. 341-342.

Viraraghavan, T., Krishnamurthy, S. and Vigneswaran, S. (2007). Public health aspects of on- site sanitation. Wastewater Recycle, Reuse, and Reclamation. (Vigneswaran, S.V., ed.). Ecolss Publishers Co. Ltd. Oxford, UK.

Visser, I.J., Vellema, P., Van Dokkum, H. and Shimada, T. (1999). Isolation of Vibrio cholerae from diseased farm animals and surface water in The Netherlands. Vet Rec. 144, pp. 451-452.

Vital, M., Füchslin, H.P., Hammes, F. and T Egli, T. (2007). Growth of Vibrio cholerae O1 Ogawa Eltor in freshwater. Microbiology. 153, pp. 1993-2001.

Wachsmuth, I.K., Blake, P.A. and Olsvik, O. (1994). Vibrio cholerae and cholera: Molecular to global perspectives. American Society for Microbiology. Washington, DC.

Wakeham, S.G., Hedges, J.L., Cindy, P., Michael, I. and Peter, J. (1997). Compositions and transport of lipid biomarkers through the water coluNA and surficial sediments of the equatorial Pacific Ocean. Deep-Sea Research Part II: Topical Studies in Oceanography. 44, pp. 2131-2162.

Waldor, M.K., Colwell, R.R. and Mekalanos, J.J. (1994). The Vibrio cholerae O139 serogroup antigen includes an O-antigen capsule and lipopolysaccharide virulence determinants. Proceedings of the National Academy of Sciences of the United States of America. 91, pp. 11388-11392.

Waldor, M.K. and Mekalanos, J.J. (1996). Lysogenic conversion by a filamentous phage encoding cholera toxin. Science. 272, pp. 1910-1914.

Wang, D., Xu, X., Deng, X., Chen, C., Li, B., Tan, H. et al. (2010). Detection of Vibrio cholerae O1 and O139 in environmental water samples by an immunofluorescent-aggregation assay. Applied and Environmental Microbiology. 76, pp. 5520-5525.

Wang, X.M., Wang, D.C., Tan, H.L., Zhong, H.J., Chen, J.D., Li, B.S. et al. (2007). Development and application of real-time polymerase chain reaction to detect Vibrio cholerae $\mathrm{O1}$ and 0139 in river water. Chinese journal of Epidemiology. 28, pp. 
768-771.

West, P.A. (1989). The human pathogenic vibrios, a public health update with environmental perspectives. Epidemiology and Infection. 103, pp. 1-34.

WHO (2017). Weekly epidemiological record. Cholera, 2016. 92, pp. 512-536.

WHO (2016). Weekly epidemiological record. Cholera, 2015. 91, pp. 433-440.

WHO (2014). Weekly epidemiological record. Cholera, 2013. 89, pp. 345-356.

WHO (2013). Weekly epidemiological record. Cholera, 2012. 88, pp. 321-336.

WHO (2012). Weekly epidemiological record. Cholera, 2011. 87, pp. 289-304.

WHO (2011). Weekly epidemiological record. Cholera, 2010. 86, pp. 325-340.

WHO (2011). Guidelines for drinking water quality, 4th edition. World Health Organization.

WHO (2010). Weekly epidemiological record. Cholera, 2009. 85, pp. 293-308.

WHO (2009). Cholera: Global surveillance. Summary, 2008. Wkly Epidemiol Rec. 84, pp. 309-323.

WHO (2009). Cholera: global surveillance summary, 2008. Wkly Epidemiol Rec. 84, pp. 309-324.

WHO (2008). Weekly epidemiological record. Cholera, 2007. 83, pp. 269-284.

WHO (2007). Weekly epidemiological record. Cholera, 2006. 82, pp. 273-284.

WHO (2006). Weekly epidemiological record. Cholera, 2005. 81, pp. 297-308.

WHO (2005). Weekly epidemiological record. Cholera, 2004. 80, pp. 261-268.

WHO (2004). Weekly epidemiological record. Cholera, 2003. 79, pp. 281-288.

WHO (2003). Weekly epidemiological record. Cholera, 2002. 78, pp. 269-276.

WHO (2003). Emerging Issues in Water and Infectious Disease. World Health Organization.

WHO (2002). Weekly epidemiological record. Cholera in 2001. 77, pp. 257-268.

WHO (2001). Weekly epidemiological record. Cholera in 2000. 76, pp. 249-256.

WHO (2000). Weekly epidemiological record. Cholera in 1999. 75, pp. 249-256.

WHO (1999). Weekly epidemiological record. Cholera in 1998. 74, pp. 257-264.

WHO (1998). Weekly epidemiological record. Cholera in 1997. 73, pp. 201-208.

WHO (1997). Weekly epidemiological record. Cholera in 1996. 72, pp. 229-239.

WHO (1996). Weekly epidemiological record. Cholera in 1995. 71(21), pp. 157-164.

WHO, UNICEF (2012). Progress on drinking-water and sanitation: 2012 update. Geneva, World Health Organization/UNICEF Joint Monitoring Programme on Water Supply and Sanitation, 2012.

Winiecka-Krusnell, J. and Linder, E. (2001). Bacterial infections of free-living amoebae. Research in Microbiology. 152, pp. 
613-619.

Yadava, J.P., Jain, M. and Goel, A.K. (2013). Detection and confirmation of toxigenic Vibrio cholerae O1 in environmental and clinical samples by a direct cell multiplex PCR. Water SA. 39, pp. 611-614.

Yamai, S., Okitsu, T., Shimada, T. and Katsube, Y. (1997). Distribution of serogroups of Vibrio cholerae non-O1 non-O139 with specific reference to their ability to produce cholera toxin and addition of novel serogroups. Kansenshogaku zasshi. The Journal of the Japanese Association for Infectious Diseases. 71, pp. 1037-1045.

Yamasaki, E., Sakamoto, R., Matsumoto, T., Morimatsu, F., Kurazono, T., Hiroi, T. et al. (2013). Development of an immunochromatographic test strip for detection of cholera toxin. BioMed Research Internationational Vol 2013.

Yildiz, F.H. and Schoolnik, G.K. (1999). Vibrio cholerae 01 El Tor: identification of a gene cluster required for the rugose colony type, exopolysaccharide production, chlorine resistance, and biofilm formation. Proceedings of the National Academy of Sciences of the United States of America. 96, pp. 4028-4033.

Yu, C.Y., Ang, G.Y., Chan, K.G., Banga-Singh, K.K. and Chan, Y.Y. (2015). Enzymatic electrochemical detection of epidemiccausing Vibrio cholerae with a disposable oligonucleotide-modified screen-printed bisensor coupled to a dry-reagent-based nucleic acid amplification assay. Biosensors and Bioelectronics. 70, pp. 282-288. 